\begin{tabular}{|l|l|}
\hline $\begin{array}{l}\text { 2. To: (Receiving Organization) } \\
\text { Distribution }\end{array}$ & $\begin{array}{l}\text { 3. From: (Originating Organization) } \\
\text { Immobilized Waste Storage }\end{array}$ \\
\hline $\begin{array}{l}\text { 5. Proj./Prog./Dept./Div.: } \\
\text { Immobilized Waste Disposal }\end{array}$ & $\begin{array}{l}\text { 6. Design Authority/Design Agent/Cog. Engr.: } \\
\text { D. A. Burbank }\end{array}$ \\
\hline
\end{tabular}

\section{Originator Remarks:}

Final report for release

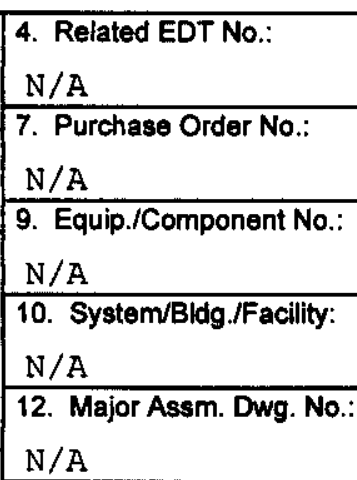

13. Permit/Permit Application No.:

$\mathrm{N} / \mathrm{A}$

14. Required Response Date:

$\mathrm{N} / \mathrm{A}$

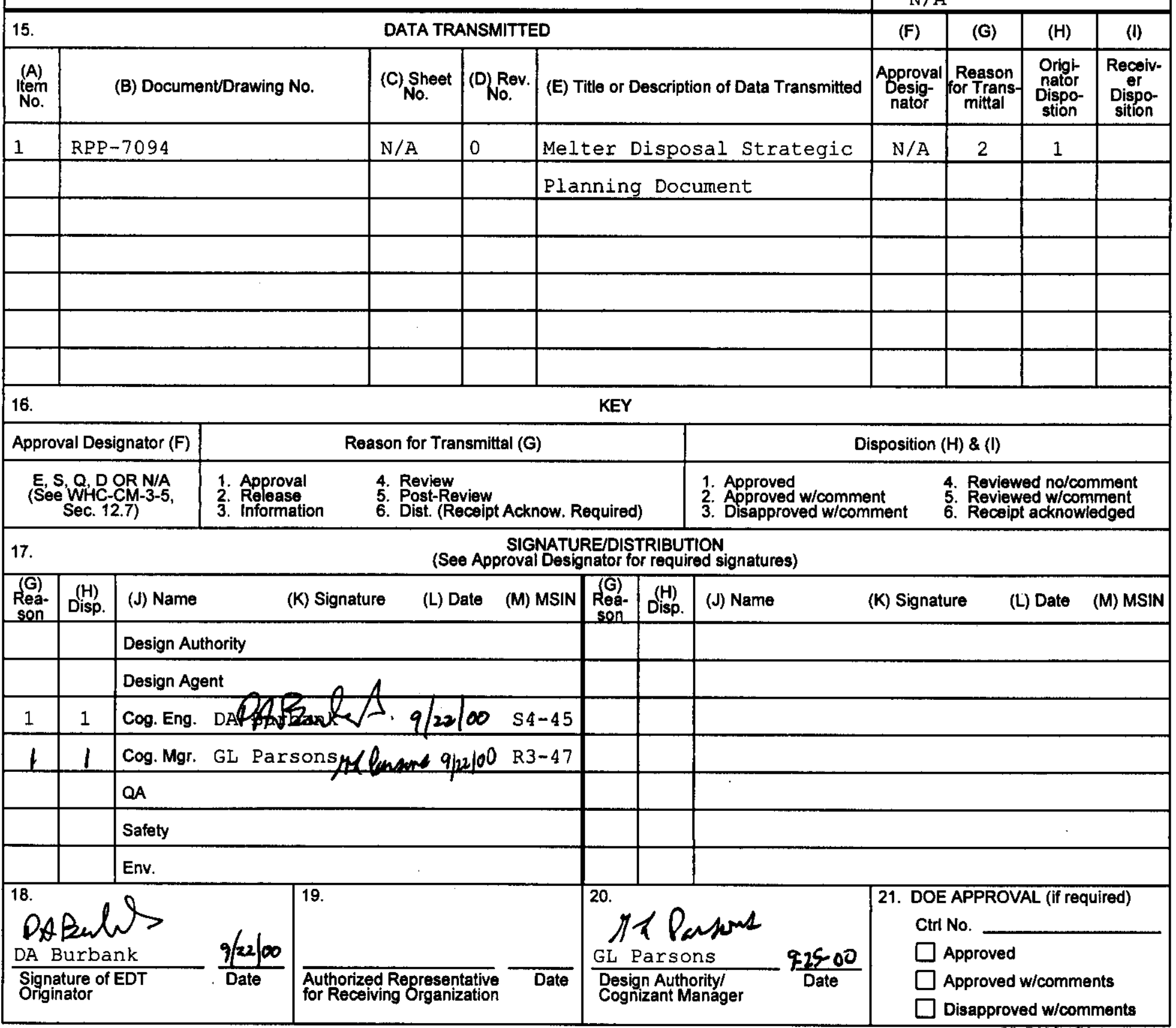




\title{
Melter Disposal Strategic Planning Document
}

D. A. Burbank, R. B. Calmus, G. Chevrier, K. I. Hladek, K. M. MaDonald CH2M HILL Hanford Group, Inc., and Fluor Hanford, Inc.

Richland, WA 99352

U.S. Department of Energy Contract DE-AC06-99RL14047

\author{
EDT/ECN: \\ UC: 721 \\ Cost Center: $7 \mathrm{~J} 200$ \\ Charge Code: 105859AA30 \\ B\&R Code: EW3130010 \\ Total Pages: 160
}

Key Words: ILAW, IHLW, Vitrification, Immobilized Waste, Solid Waste, 218-E-12B, Leachate, River Protection Project

Abstract: This document describes the proposed strategy for disposal of spent and failed melters from the tank waste treatment plant to be built by the office of River Protection at the Hanford site in Washington. It describes program management activities, disposal and transportation systems, leachate management, permitting, and safety authorization basis approvals needed to execute the strategy.

TRADEMARK DISCLAIMER. Reference herein to any specific commercial product, process, or service by trade name, trademark, manufacturer, or otherwise, does not necessarily constitute or imply its endorsement, recommendation, or favoring by the United States Government or any agency thereof or its contractors or subcontractors.

Printed in the United States of America. To obtain copies of this document, contact: Document Control Services, P.O. Box 950, Mailstop H6-08, Richland WA 99352, Phone (509) 372-2420; Fax (509) 376-4989.
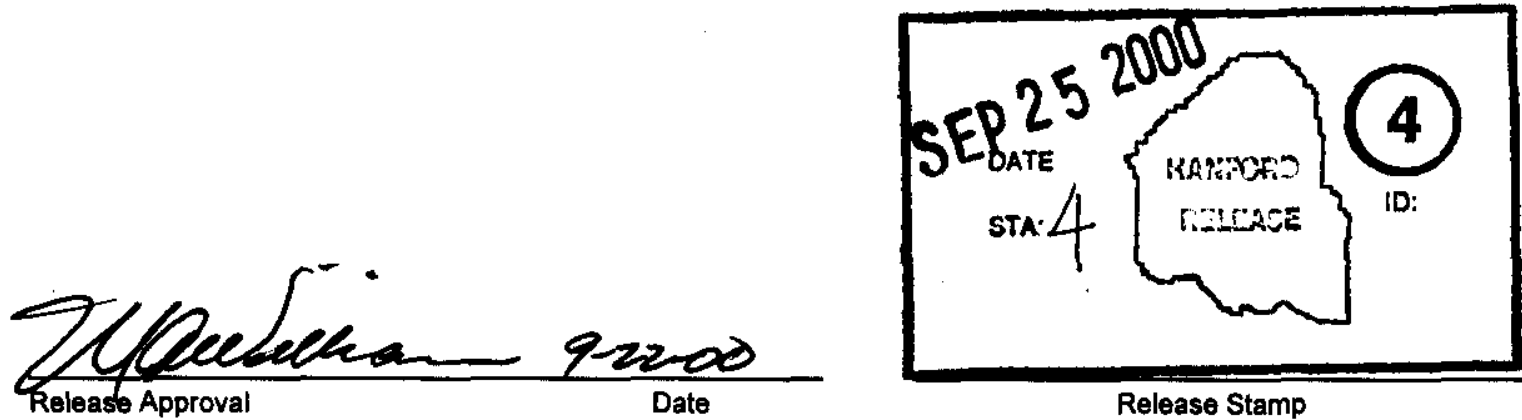

Release Stamp 


\section{Melter Disposal Strategic Planning Document}

Prepared for the U.S. Department of Energy

Assistant Secretary for Environmental Management

\section{CH2MHILL \\ Hanford Group, Inc.}

Richland, Washington

Contractor for the U.S. Department of Energy

Office of River Protection under Contract DE-AC06-99RL14047

Approved for Public Release; Further Dissemination Unlimited 
RPP-7094

Revision 0

\section{Melter Disposal Strategic Planning Document}

D. A. Burbank

R. B. Calmus

CH2M HILL Hanford Group, Inc.

G. P. Chevrier

K. L. Hladek

K. M. McDonald

Fluor Hanford, Inc.

Date Published

September 2000

\section{CH2MHILL \\ Hanford Group, Inc.}

P. O. Box 1500

Richland, Washington

Contractor for the U.S. Department of Energy

Office of River Protection under Contract DE-AC06-99RL14047

Approved for Public Release; Further Dissemination Unlimited 
LEGAL DISCLAIMER

This report was prepared as an account of work sponsored by an agency of the United States Government. Neither the United States Government nor any agency thereof, nor any of their employees, nor any of their contractors, subcontractors or their employees, makes any warranty, express or implied, or assumes any legal liability or responsibility for the accuracy, completeness, or any third party's use or the results of such use of any information, apparatus, product, or process disclosed, or represents that its use would not infringe privately owned rights. Reference herein to any specific commercial product, process, or service by trade name, trademark, manufacturer, or otherwise, does not necessarily constitute or imply its endorsement, recommendation, or favoring by the United States Government or any agency thereof or its contractors or subcontractors. The views and opinions of authors expressed herein do not necessarily state or reflect those of the United States Government or any agency thereof.

This report has been reproduced from the best available copy. Available in paper copy and microfiche.

Available electronically at http:/www.doe.gov/bridge. Available for a processing fee to the U.S. Department of Energy and its contractors, in paper, from:

U.S. Department of Energy

Office of Scientific and Technical Information

P.O. Box 62

Oak Ridge, TN $37831-0062$

phone: $865-576-8401$

fax: 865-576-5728

email: reports@adonis.osti.gov(423) 576-8401

Available for sale to the public, in paper, from:

U.S. Department of Commerce

National Technical Information Service

5285 Port Royal Road

Springfield, VA 22161

Phone: 800-553-6847

fax: 703-605-6900

email: orders@ntis.fedworld.gov

online ordering:

http://www.ntis.gov/ordering.htm 
RPP-7094 REV 0

\section{EXECUTIVE SUMMARY}

U.S. Department of Energy Office of River Protection (DOE-ORP) baseline planning calls for treatment and immobilization of Hanford tank waste by vitrification. Phase I vitrification, with a duration of 12 years, will process both high-level waste and lowactivity waste streams. Spent and failed melters from this process constitute a secondary waste stream that requires disposal.

This strategy document addresses four principal areas of concern regarding the overall failed melter disposal process: production, transportation, disposal, and programmatic (permitting/cost/schedule) issues. For these areas the preferred strategies are

Production. Thirteen failed melters are assumed as the baseline for Phase I vitrification, although a detailed decision analysis discussed in Chapter 2 indicates that the $95 \%$ confidence level is bounded by 19 failed melters. A maximum of three failed melters may need to be disposed of in a given 12-month period. This maximum production rate is used for transportation resource planning.

Transportation. Four options are investigated for failed melter transport in Chapter 3. They include use of the existing naval reactor transporter, use of the vitrification facility's melter transporter, lease of a vehicle other than the naval reactor transporter, and procurement of a vehicle dedicated exclusively to failed melter transport. All options require significant roadway upgrades. At least one Safety Analysis Report for Packaging (SARP) will be required for failed melter transportation. 
Disposal. The preferred melter disposal trench location is in the 200 East Area, in the unused west section of the 218-E-12B burial ground. This is closest to the planned vitrification facility site. The baseline melter trench design discussed in Chapter 4 mimics the naval reactor compartment trench, and will be sized to accommodate melters from Phase I vitrification with expansion capability for future modules. Two liners and a leachate collection/removal system are required per the Washington Administrative Code. Leachate will be transported to the 200 Area Liquid Waste Processing Facilities for treatment. An Alternate Generation Analysis is planned for fiscal year 2001 to evaluate trench and leachate handling options.

Programmatic. Programmatic issues include Resource Conservation and Recovery Act permitting and other required environmental documentation. As a baseline, grouted spent and failed melters are assumed to comply with Land Disposal Restrictions as they are released from the vitrification facility. A path of preferred strategies, along with feasible options, is laid out in Chapter 5 along with cost and schedule estimates for meeting the programmatic and regulatory requirements.

Costs. A summary of the costs for selected alternatives is shown below.

\begin{tabular}{|l|l|l|l|l|}
\hline Description & Baseline & $\begin{array}{l}\text { Baseline with } \\
\text { Vitrification } \\
\text { Plant Transporter }\end{array}$ & $\begin{array}{l}\text { Baseline with } \\
\text { Leased } \\
\text { Transporter }\end{array}$ & $\begin{array}{l}\text { Baseline with } \\
\text { Dedicated } \\
\text { Transporter }\end{array}$ \\
\hline $\begin{array}{l}\text { Engineering and } \\
\text { Development }\end{array}$ & $\$ 6,440 \mathrm{~K}$ & $\$ 6,440 \mathrm{~K}$ & $\$ 6,440 \mathrm{~K}$ & $\$ 6,440 \mathrm{~K}$ \\
\hline Construction & $\$ 6,600 \mathrm{~K}$ & $\$ 6,600 \mathrm{~K}$ & $\$ 6,600 \mathrm{~K}$ & $\$ 6,600 \mathrm{~K}$ \\
\hline $\begin{array}{l}\text { Operations and } \\
\text { Transportation }\end{array}$ & $\$ 15,660 \mathrm{~K}$ & $\$ 8,260 \mathrm{~K}$ & $\$ 16,960 \mathrm{~K}$ & $\$ 11,660 \mathrm{~K}$ \\
\hline Total & $\mathbf{\$ 2 8 , 7 0 0 ~ K}$ & $\mathbf{\$ 2 1 , 3 0 0 ~ K}$ & $\mathbf{\$ 3 0 , 0 0 0 ~ K}$ & $\mathbf{\$ 2 4 , 7 0 0 ~ K}$ \\
\hline
\end{tabular}




\section{RPP-7094 REV 0}

The melter disposal project will need to begin early in fiscal year 2001 in order to meet Phase I vitrification project deadlines. This is driven by the various applicable permitting processes, as regulatory and permitting issues generally require long lead times for reviews, public comment periods, and regulator approvals.

In-depth background and supporting data for this strategy document is provided in the attached Appendixes. 


\section{ABREVIATIONS and ACRONYMS}

\begin{tabular}{|c|c|}
\hline ALARA & as low as reasonably achievable \\
\hline AOP & air operating permit \\
\hline ARARs & applicable or relevant and appropriate requirements \\
\hline BACT & best available control technology \\
\hline BARCT & best available radionuclide control technology \\
\hline $\mathrm{BCAA}$ & Benton Clean Air Authority \\
\hline BFHD & Benton-Franklin District Health Department \\
\hline BMP & Hanford best management practice \\
\hline CAA & Clean Air Act of 1977 \\
\hline CDR & conceptual design report \\
\hline CERCLA & $\begin{array}{l}\text { Comprehensive Environmental Response, Compensation, } \\
\text { and Liability Act of } 1980\end{array}$ \\
\hline CERR & Cultural/Ecological Resources Review \\
\hline $\mathrm{CFCs}$ & chlorofluorocarbons \\
\hline CFR & Code of Federal Regulations \\
\hline CQA & construction quality assurance (plan) \\
\hline CRR & cultural resource review \\
\hline CWA & $\begin{array}{l}\text { Clean Water Act (including Safe Drinking Water Act 1986, } \\
\text { and many included reference documents) }\end{array}$ \\
\hline CX & categorical exclusion \\
\hline DOE-HQ & U.S. Department of Energy-Headquarters \\
\hline DOE-RL & U.S. Department of Energy, Richland Operations Office \\
\hline DNR & Department of Natural Resources \\
\hline DNS & determination of non-significance (by Ecology) \\
\hline DST & double-shell tank \\
\hline DTS & deficiency tracking system \\
\hline EA & environmental assessment \\
\hline Ecology & Washington State Department of Ecology \\
\hline EIS & environmental impact statement \\
\hline EIS/ODIS & $\begin{array}{l}\text { effluent information system/onsite discharge information } \\
\text { system }\end{array}$ \\
\hline EPA & U.S. Environmental Protection Agency \\
\hline FH & Fluor Hanford, Inc. \\
\hline FR & Federal Register \\
\hline FONSI & finding of no significant impact \\
\hline gpd & gallons per day \\
\hline HCRL & Hanford Cultural Resource Laboratory \\
\hline HLAN & Hanford Local Area Network \\
\hline HLW & high-level waste \\
\hline HPA & Hydraulic Projects Approval \\
\hline IEU & insignificant emission units \\
\hline LAW & low-activity waste \\
\hline MEI & maximally exposed individual \\
\hline mrem & millirem \\
\hline
\end{tabular}


MTF

MWC

NEPA

NESHAPS

NOC

NOI

NPDES

NSR

PAA

PCB

PHMC

POC

PL

PNNL

PSD

RCRA

RPP

SEPA

SST

SWDP

TAPs

T-BACT

TEDE

T-RACT

Tri-Party Agreement (TPA)

TRU

TSCA

TSD

TWRS

UIC

USACE

USFWS

UST

WAC

WDOH

WMH

WMP memorandum-to-file (not in current usage)

municipal waste combustor

National Environmental Policy Act of 1969

National Emission Standards for Hazardous Air Pollutants

notice of construction

notice of intent

National Pollutant Discharge Elimination System

new source review

Price-Anderson Amendments (review)

polychlorinated biphenyl(s) (specially regulated substance)

Project Hanford Management Contract

point of contact

Public Law

Pacific Northwest National Laboratory

Prevention of Significant Deterioration

Resource Conservation and Recovery Act of 1976

River Protection Project (under the DOE Office of River

Protection)

Washington State Environmental Policy Act of 1971

single-shell tank

State Waste Discharge Permit

toxic air pollutants

best available control technology for toxics

total effective dose equivalent

reasonably available control technology for toxics

Hanford Federal Facility Agreement and Consent Order

transuranic (material/elements/waste)

Toxic Substances Control Act of 1976

treatment, storage, and/or disposal

Tank Waste Remediation System

underground injection control

U.S. Army Corps of Engineers

U.S. Fish and Wildlife Service

underground storage tanks

Washington Administrative Code

Washington State Department of Health

Waste Management Federal Services of Hanford, Inc.

Waste Management (Hanford Primary) Project 


\section{CONTENTS}

1.0 INTRODUCTION

1.1 BACKGROUND

1.2 SCOPE

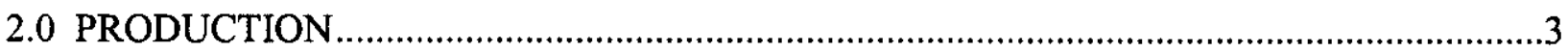

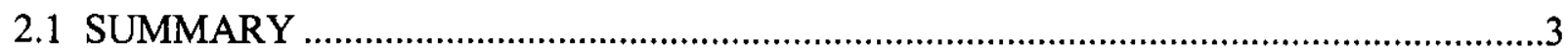

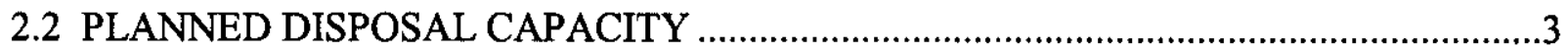

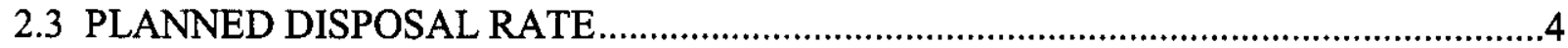

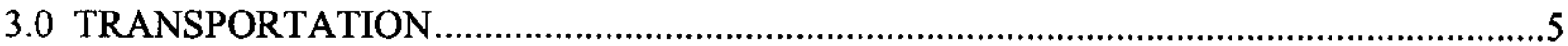

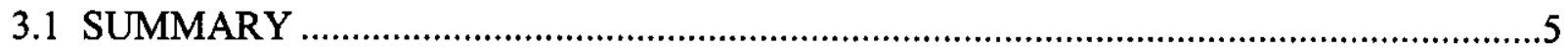

3.2 MELTER TRANSPORTATION SAFETY DOCUMENTATION .......................................

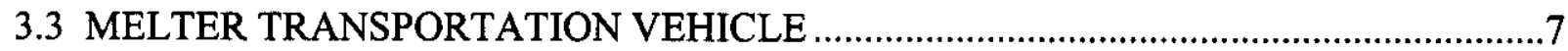

3.3.1 Option 1-Lease and Use of the Existing Naval Reactor Compartment Transporter ...7

3.3.2 Option 2-Use of the Vitrification Plant Facility Transporter....................................10

3.3.3 Option 3-Use of a Leased Transporter Other Than the Transporter Used..................12

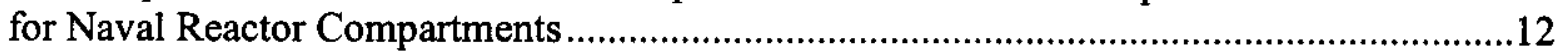

3.3.4 Option 4-Procurement of a Dedicated Transporter System .....................................13

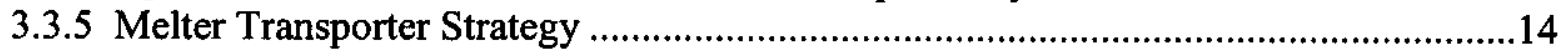

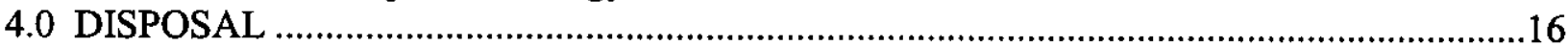

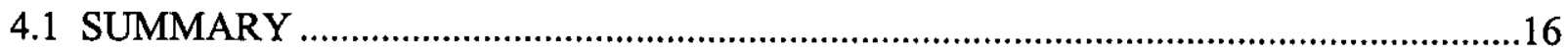

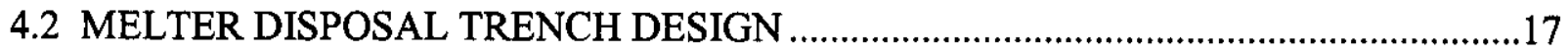

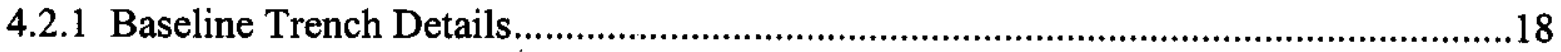

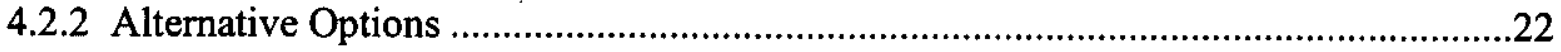

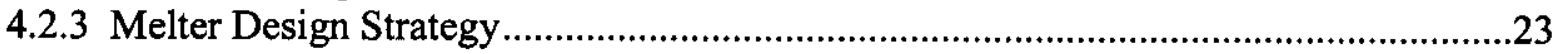

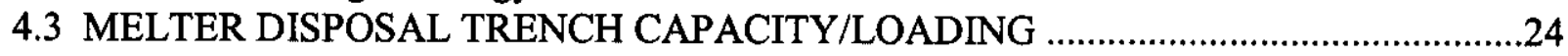

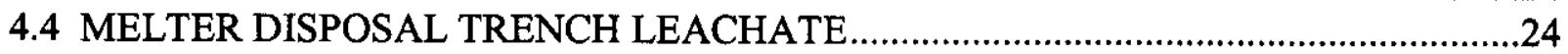

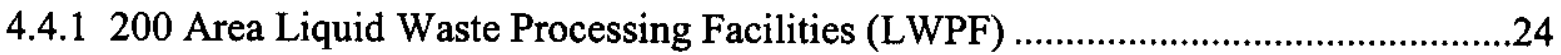

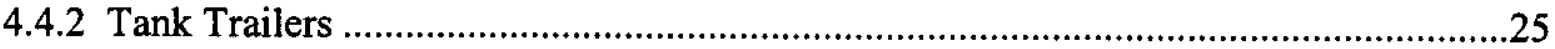

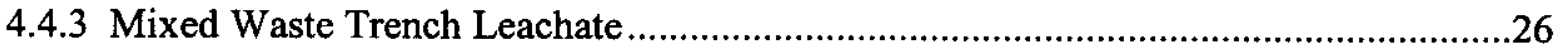

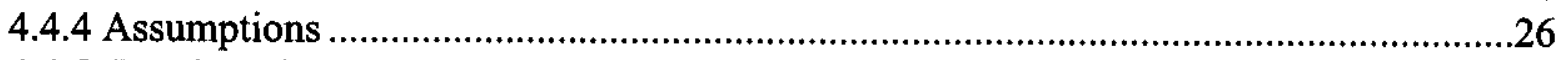

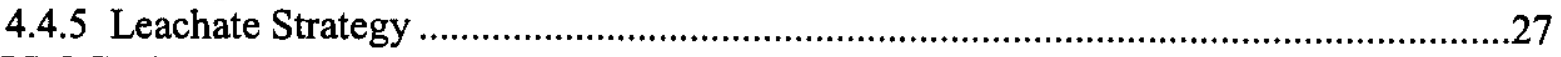

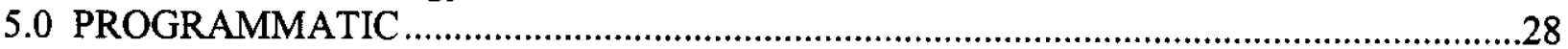

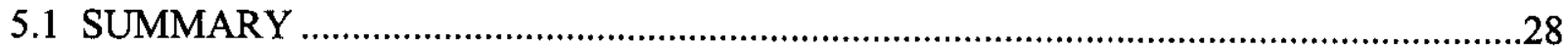

5.2 MELTER DISPOSAL TRENCH RCRA PERMITTING .............................................28

5.2.1 Alternatives For Satisfying Applicable RCRA Requirements ...................................31

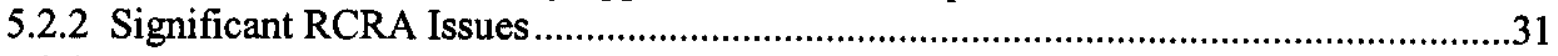

5.2.3 Recommended Approach for Complying With RCRA ..............................................32

5.3 MELTER DISPOSAL TRENCH OTHER ENVIRONMENTAL DOCUMENTATION..32

5.3.1 Federal and State Environmental Policy Acts ..........................................................33

5.3.2 Cultural Resources And Ecological Compliance Reviews ……...................................36

5.3.3 Environmental Monitoring of Facilities, Sites, and Operations ..................................38

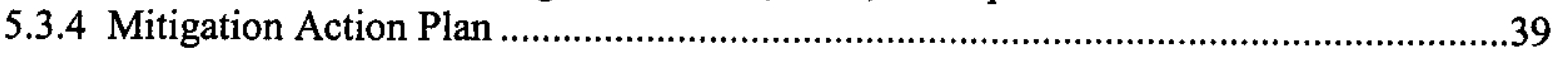

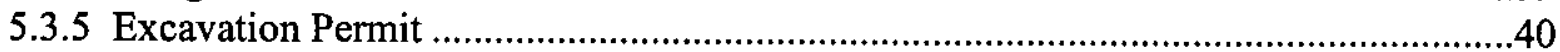

5.3.7 DOE Acquisition/Environment, Safety and Health Management...............................41 


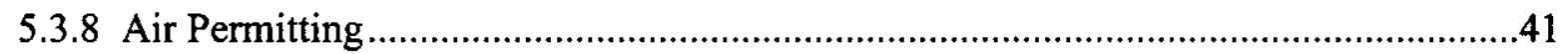

5.3.9 Water And Waste Water Management ................................................................45

5.3.10 Radioactive Materials And Waste Management .................................................48

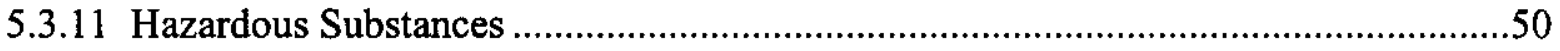

5.3.12 Hanford Site Solid Waste Acceptance Criteria (HSSWAC) ...................................50

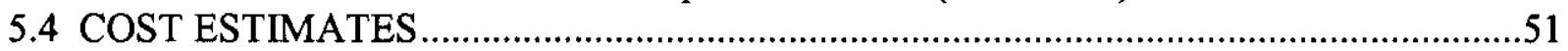

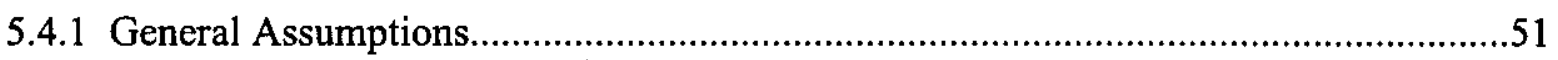

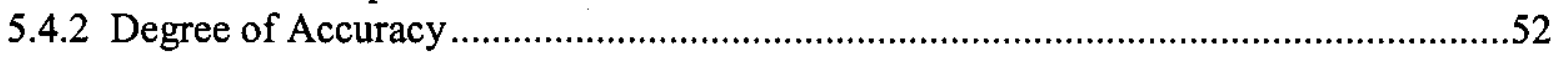

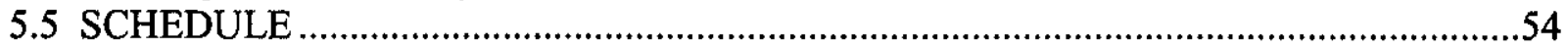

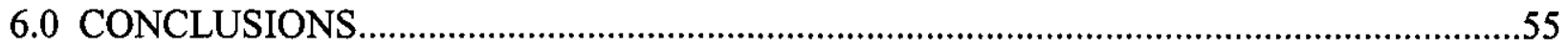

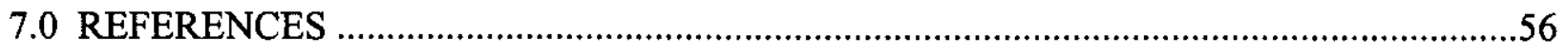

\section{APPENDICES}

A. A STUDY OF LEACHATE MANAGEMENT AT THE HANFORD SITE ..................... A-I

B. SCHEDULE OF ACTIVITIES IN PREPARATION FOR SPENT/FAILED MELTER

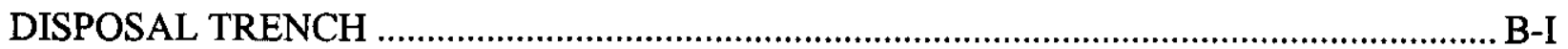

C. PROJECTED PHASE 1 DISPOSAL RATES FOR FAILED MELTERS .......................... C-I

D. HIGH LEVEL WASTE (HLW) MELTER AND LOW ACTIVITY WASTE (LAW) MELTER TRANSPORTATION FROM THE VITRIFICATION FACILITY TO THE DISPOSAL TRENCH

E. MELTER DISPOSAL TRENCH DESIGN ASSUMPTIONS........................................... E-I

F. ENVIRONMENTAL COMPLIANCE CHECKLIST ......................................................

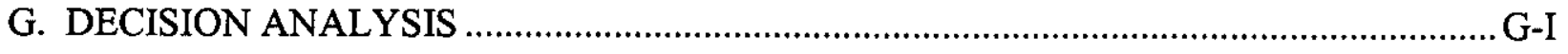




\section{LIST OF FIGURES}

Figure 1. 218-E-12B Burial Ground and Potential Melter Disposal Trench Location................ 17

Figure 2. General Layout of Baseline Melter Trench............................................................ 18

Figure 3. Phase I Trench Layout................................................................................... 20

Figure 4. Phase II Trench Layout. .................................................................................... 21

\section{LIST OF TABLES}

Table 1. Cost and Schedule Estimates for RCRA Permitting Activities......................................30

Table 2. Cost and Schedule Estimates for NEPA/SEPA Compliance.............................................33

Table 3. Cost and Schedule Estimates for Cultural and Ecological Reviews.............................. 37

Table 4. Cost and Schedule Estimates for Excavation Permit....................................................... 40

Table 5. Cost and Schedule Estimates for Radioactive Air Permits............................................ 43

Table 6. Cost and Schedule Estimates for Nonradioactive Air Permits..................................... 43

Table 7. Cost and Schedule Estimates for Air Operating Permit Modification.............................. 44

Table 9. Cost and Schedule Estimates for Water and Wastewater Management. ........................ 45

Table 10. Cost and Schedule Estimates for Radioactive Waste Management. ........................... 48

Table 11. Cost and Schedule Estimates for Performance Assessment/Composite Analysis...... 49

Table 12. Cost and Schedule Estimates Waste Acceptance Criteria. ...........................................5 51

Table 13. Melter Disposal Costs, Baseline and Alternative Options............................................ 53 
RPP-7094 REV 0

This page intentionally left blank. 


\section{MELTER DISPOSAL STRATEGIC PLANNING DOCUMENT}

\subsection{INTRODUCTION}

\subsection{INTRODUCTION}

The U.S. Department of Energy (DOE) Office of River Protection (ORP) and its contractors have proposed to treat and immobilize tank waste using a vitrification process. According to current design, treatment and immobilization will be done after a pretreatment has separated the waste into a high-level waste (HLW) stream and an associated low-activity waste (LAW) stream. Spent and failed melters from vitrification of these two streams have been identified as a secondary waste that requires disposal. Significant programmatic issues have been identified relative to disposal of these melters.

The melters and the vitrification process are still early in the design stage. However, other activities such as disposal trench design, transportation design, and permitting must occur concurrently with melter and process design because they are long-lead items. The River Protection Project (RPP) has developed this Melter Disposal Strategic Planning Document to present a disposal strategy/path forward as part of the FY 2000 Retrieval and Disposal activities. Assumptions have been made relative to the melters and the interface between the waste treatment contractor (WTC) and DOE to provide the necessary capabilities for final melter disposal. These assumptions (Burbank and Calmus, 2000) were previously provided to DOE$\mathrm{ORP}$, and are the basis for the strategy decisions presented in the subject document. The strategy is valid only for Phase 1 of the vitrification program, i.e., the first 12-year contract.

In January of 2000, DOE and representatives from the WTC and tank farm contractor met in a three-day workshop to better define the basis for melter disposal. The workshop provided baseline information about the size, weight, and configuration of spent melters that were ready for disposal. The HLW melter will be placed in a shielded overpack box that is about 21 feet long. 18 feet wide, and 16 feet tall, weighing up to 500 tons. The LAW melter will be integrally shielded, grouted in a package that is about 27 feet long, 15 feet wide, and 16 feet tall, weighing up to 710 tons.

The current multi-year work plan for melter disposal includes separate projects for HLW and LAW melter transportation systems, with a single trench for disposal of both types of melter. This strategy document studies alternatives to the current plan and proposes a new strategy based on a single transporter system and a trench dedicated to melter disposal only.

\subsection{SCOPE}

The scope of the Melter Disposal Strategic Planning Document is to define the strategy for receiving, transporting, and disposing of failed vitrification melters by examining the overall system and each phase of the melter trench development assuming a "baseline" melter condition. Viable alternatives and issues within each area of program/project planning are identified where 


\section{RPP-7094 REV 0}

further study is merited. A formalized decision tree was developed to assess the impacts of variability within the melter envelope. Lastly, cost and schedule estimates are provided for the baseline strategy.

The strategy has been divided into four separate elements The elements have been developed based on the general breakout of assumptions in the assumptions document. They will be addressed in a similar manner. These areas are as follows:

- Production, which includes assumptions relative to schedule, production rate, etc.

- Transportation, which includes assumptions relative to transportation of the melters from the WTC site to the disposal site

- Disposal, which includes assumptions relative to the disposal process

- Programmatic, which includes Permitting and other Environmental Documentation, Cost and Schedule. 


\subsection{PRODUCTION}

\subsection{SUMMARY}

This section examines the production of failed melters during Phase I vitrification.

Two scenarios are analyzed. The first, derived from projections of melter life, estimates a total of 15.6 failed melters. The second scenario, based on a PNNL study of melter failure modes, estimates 18.6 failed melters. The expected numbers are based upon the WTC approach. A new contractor or changes in approach may change the assumptions, and they should be reevaluated when more information is available.

The baseline assumption of 13 failed melters from Burbank and Calmus (2000) is used for the purposes of this document. However, in light of the two scenarios that are analyzed herein, it is recommended that the Phase I Melter Trench be designed for a bounding capacity of 19 failed melters.

A Monte Carlo simulation indicates that a maximum of three failed melters may need to be disposed of in any given 12-month period during Phase I vitrification activities. This maximum production rate is subsequently used for planning of transportation resources elsewhere in this document.

\subsection{PLANNED DISPOSAL CAPACITY}

An analysis was performed to develop confidence intervals for the expected number of failed/ spent melters that will require disposal during Phase 1 of the tank waste treatment program. Two scenarios were analyzed.

\section{Scenario 1:}

The projected life of LAW and HLW melters is three years (Burbank and Calmus, 2000). For this analysis, a triangular distribution for melter life was assumed with a minimum value of 1 year, a mode of 3 years, and a maximum value of 5 years. All melter failures were generated using this single distribution.

The $95 \%$ confidence interval for this scenario is based on 100 replications of the statistical model is $15.4<u<15.8$ melters. The average over the 12 years of Phase 1 is 15.6 failed melters.

The data used to develop the confidence intervals for Scenario 1 is summarized in Appendix C, Attachment 1.

\section{Scenario 2:}

PNNL-11014 discusses three possible failure modes for melters: failure mode 1-temperature too low, failure mode 2-temperature too high, and failure mode 3-maximum current 


\section{RPP-7094 REV 0}

exceeded. PNNL-11014 also suggests triangular distributions for the expected life of a melter under each of these three failure modes.

For the purpose of this analysis, the three failure modes were considered to be equally likely; i.e., each of the distributions was used to generate, on average, one-third of the failures.

Based on 100 replications, the $95 \%$ confidence interval for number of failures is $18<u<19.2$ failed melters. The average over the 13 years of Phase 1 is 18.6 failed melters.

The data used to develop the confidence intervals for Scenario 2 is summarized in Appendix C, Attachment 2.

It should be noted that these results are preliminary. A peer review by domain experts should be conducted during trench design to validate the assumptions and logic used in developing the failure distributions. A statistician should also peer review the statistical assumptions.

STRATEGY. For purposes of this document a capacity of 13 melters was used, based on the Assumptions document, however, the analysis above suggests that for future efforts in the area of trench design and other planning needs the Phase I Melter Trench should be designed with a capacity for 19 melters. This appears to be consistent with reasonable engineering judgment of adding 50\% capacity to account for uncertainties.

\subsection{PLANNED DISPOSAL RATE}

Based upon the number of melters in use at a given time, and the assumed failure/programmatic replacement rate, a Monte Carlo simulation was performed to determine the maximum number of melters that may require disposal in a given year. Based upon this analysis, three melters may be expected within a 12-month window.

The data used to develop the confidence intervals for Scenario 2 is summarized in Appendix C, Attachment 3.

STRATEGY. For purposes of planning transportation vehicle availability, etc. a maximum of three melters may be expected in a given year. 


\subsection{TRANSPORTATION}

\subsection{SUMMARY}

This section lays out strategies and needs for transportation of failed melter packages in the areas of safety documentation and transport vehicle options. It is assumed for all options that an onsite transport configuration will be used to provide equivalent safety to the U.S. Department of Transportation (DOT) Regulations per DOE-RL direction, in lieu of compliance with DOT Regulations. Thus, at least one Safety Analysis Report for Packaging (SARP) will be required. A SARP schedule is estimated at one to two years, with an approximate cost of $\$ 150-200 \mathrm{~K}$. SARP preparation should begin as soon as the necessary input information is available.

Four transport vehicle options are examined for shipment of failed vitrification melters. Descriptions and rough cost estimates are as follows:

1. Lease of the existing naval reactor compartment transporter. Rough cost: $\$ 540 \mathrm{~K}$ per melter shipment.

2. Use of the vitrification facility melter transporter. Rough cost: $\$ 40 \mathrm{~K}$ per shipment, plus $\$ 2,100 \mathrm{~K}$ for procurement and $\$ 1500 \mathrm{~K}$ for lifetime maintenance.

3. Use of a leased transporter other than the naval reactor transporter. Rough cost: $\$ 640 \mathrm{~K}$ per shipment, $\$ 900 \mathrm{~K}$ for transporter modifications.

4. Procurement of a dedicated transporter for failed melters. This option essentially doubles the cost of Option 2, as two separate melter transporter systems would be purchased and utilized (one for moving melters within the facility, and one for failed melter transport to the disposal trench).

In addition, all options require approximately $\$ 645 \mathrm{~K}$ for roadway upgrades.

\subsection{MELTER TRANSPORTATION SAFETY DOCUMENTATION}

Movement of the melters from the Vitrification facility to the disposal trench requires safety basis documentation. It is assumed that the melters, in a configuration for transport (melter in overpack), will not be in compliance with DOT regulations. Therefore, in accordance with RL direction, equivalent safety to DOT regulations is required. The basis for establishing equivalent safety to DOT regulations using certain restrictions, administrative controls, and analysis of package safety is provided in an Onsite SARP. The analysis of the payload will establish the authorization of the activity limits, procedures, controls, and restrictions acceptable for achievement of equivalent safety to DOT regulations. Dose rates and contamination levels associated with the melter package and the transporter utilized will be in accordance with DOT limitations or limitations specified in the SARP. 
Summary of Costs for Melter Transportation Options

\begin{tabular}{|c|c|c|c|c|}
\hline \multirow{2}{*}{\begin{tabular}{|c|} 
Alternative for \\
Transporting Spent \\
Melters from Vit Facility \\
to Trench
\end{tabular}} & 1 & 2 & 3 & 4 \\
\hline & $\begin{array}{c}\text { Use } \\
\text { Submarine } \\
\text { Transporter }\end{array}$ & $\begin{array}{l}\text { Use Vit } \\
\text { Contractor's } \\
\text { Transporter }\end{array}$ & $\begin{array}{c}\text { Lease } \\
\text { Transporter }\end{array}$ & $\begin{array}{l}\text { Purchase } \\
\text { Transporter }\end{array}$ \\
\hline Fixed Costs & 5,345 & $\underline{4,445}$ & $\underline{5,345}$ & 8,045 \\
\hline Safety Analysis Report & 200 & 200 & 200 & 200 \\
\hline Road Modifications & 645 & 645 & 645 & 645 \\
\hline Transporter Bed & 900 & $\underline{0}$ & $\underline{900}$ & $\underline{0}$ \\
\hline Design & 100 & & 100 & \\
\hline Procure & 100 & & 100 & \\
\hline Construct & 550 & & 550 & \\
\hline SAR & 150 & & 150 & \\
\hline Site engineering/training & 0 & 0 & 0 & 0 \\
\hline Procure Transporter & & & & 2,100 \\
\hline Maintain Transporter & & & & 1,500 \\
\hline \multicolumn{5}{|l|}{ Vit Contractor Assumptions } \\
\hline Procure Transporter & 2,100 & 2,100 & 2,100 & 2,100 \\
\hline Maintain Transporter & 1,500 & 1,500 & 1,500 & 1,500 \\
\hline & & & & \\
\hline Variable Costs & 7,020 & $\underline{520}$ & $\underline{8,320}$ & $\underline{520}$ \\
\hline Cost per shipment & 540 & 40 & 640 & 40 \\
\hline Number of shipments & 13 & 13 & 13 & 13 \\
\hline TOTAL COST & $\$ 12,365$ & $\$ 4.965$ & $\$ 13,665$ & $\$ 8.565$ \\
\hline
\end{tabular}

As a minimum, one SARP will be needed to document the safety of the packaging and transportation system and configuration for both the LAW melter and HLW melter. Regardless of which of the four transport vehicle options is used (see Section 3.2), the following cost and schedule will apply (one time) and must be completed and approved prior to the first shipment of a melter to the disposal trench.

Schedule: 1 to 2 years to complete an Onsite SARP. Cost: $\$ 150 \mathrm{~K}$ to $\$ 200 \mathrm{~K}$ to complete the SARP.

Note: These estimates are based upon over ten year's experience with developing SARPs for waste transportation on the Hanford Site. 
STRATEGY: Begin preparation of onsite SARP as soon as necessary information is made available. Necessary information includes final trench location, transportation route, and radionuclide inventory characterization of the proposed packages.

\subsection{MELTER TRANSPORTATION VEHICLE}

An analysis was performed to look at various options for melter transportation from the vitrification facility to the melter disposal trench. The four options that were analyzed are shown below. More details on the transportation vehicle analysis are contained in Appendix D.

Option 1 Lease and use the existing naval reactor compartment transporter

Option 2 Use of the vitrification plant facility transporter from the building to the disposal trench

Option 3 Use of a leased transporter other than the transporter used for naval reactors compartments

Option 4 Procurement of a dedicated transporter system.

\subsubsection{Option 1-Lease and Use of the Existing Naval Reactor Compartment Transporter}

Under this option, the transporter and ancillary equipment is in existence at the Hanford Site and can be scheduled for use around the naval reactor compartment movements.

The naval reactor compartment transporter and ancillary equipment are used to move naval reactor compartments to Trench 94 approximately 10 times a year (two to four reactor compartments each spring and four to six reactor compartments each fall). Water levels in the Columbia River, maintenance of Columbia River locks, and coastal waters provide prime operating conditions at these times. Each shipment requires commitment of the equipment for approximately 1 week, with 1 -week mobilization before and one week demobilization after each campaign (spring and fall). Thus, the naval reactor compartment transporter may be committed up to 14 weeks out of the year. Therefore, it is conceivable to schedule failed melter movements around naval reactor compartment movements during the remaining 38 weeks of the year without impacting either melter movement schedule or naval reactor compartment movement schedules.

3.3.1.1 Naval Reactor Compartment Transporter Shipment Schedule. Planning and mobilization for each campaign will commence 30 days prior to transport. Note that this is worst case. Mobilization could take less time (as little as two weeks if equipment was available). More than one melter can be moved in a campaign. It is estimated that each melter will require that the transporter be dedicated for approximately 1 week, similar to the naval reactor compartments. Actual movement of the melter from the Vitrification Plant or storage area near the Vitrification Plant to the disposal trench will take 1 day. Demobilization will take approximately 30 days for each campaign. 
RPP-7094 REV 0

Cost Summary for Option 1 -- Naval Reactor Compartment Transporter

\begin{tabular}{|l|r|r|}
\hline Item & Cost (\$) & Cost (\$) \\
\hline Shipment Cost & & 540,000 \\
\hline - Transporter & 178,000 & \\
\hline - Tractors & 42,000 & \\
\hline - Personnel - Contractor & 290,000 & \\
\hline - Personnel - Hanford & 30,000 & \\
\hline & & \\
\hline Transporter Modifications & & 900,000 \\
\hline - Design Modifications & 100,000 & \\
\hline - Safety Basis & 150,000 & \\
\hline - Procurement & 100,000 & \\
\hline - Fit-up/Modifications & 500,000 & \\
\hline - QA/Oversight & 50,000 & \\
\hline & & \\
\hline Roadway Modificatons & & $\mathbf{6 4 5 , 0 0 0}$ \\
\hline & & \\
\hline Total & & $\mathbf{2 , 0 8 5 , 0 0 0}$ \\
\hline
\end{tabular}

3.3.1.2 Naval Reactor Compartment Transporter Shipment Cost. The cost associated with this option is approximately $\$ 540,000.00$ per shipment. This approximate cost includes contracting for use of the existing transporter and ancillary equipment and for the service provider to operate and maintain the transporter and ancillary equipment (use of tractors, use of transporter lines, transporter mobilization efforts, transporter demobilization efforts, other materials as necessary, and associated maintenance). The approximate cost per shipment, based upon discussions with contractor marketing personnel and experience with transport of naval reactor compartments, is broken down as follows.

- $\$ 178 \mathrm{~K}$ for one transporter. This includes cost for 60 days based on a schedule for mobilization with transporter frame fit up, use, and demobilization).

- $\$ 42 \mathrm{~K}$ for two prime movers (tractors). This includes cost for 60 days based on a schedule for mobilization, use, and demobilization.

- $\$ 290 \mathrm{~K}$ for service provider engineering, crafts, labor, and other support personnel and systems.

- $\$ 30 \mathrm{~K}$ of Hanford Site cost for engineering, crafts, labor, contracts, and other support personnel and systems. This includes a planning phase of 30 to 60 days prior to transport.

3.3.1.3 Naval Reactor Compartment Transporter Logistics. Current plans for entry and exit of the disposal trench are similar in design, grade, width, and length to the naval reactor 
compartment trench where the transporter is currently utilized. The existing naval reactor compartment transporter and ancillary equipment would be ideal for entry into the melter disposal trench and exit based on current plans. The total length of the transporter system (including prime movers is approximately $226 \mathrm{ft}(69 \mathrm{~m})$. The transporter system carries 22 lines of tires with a length of $116 \mathrm{ft}(36 \mathrm{~m})$ long by $24 \mathrm{ft}(8 \mathrm{~m})$ wide by $4 \mathrm{ft}(1.2 \mathrm{~m})$ high. The inside turning radius is $40 \mathrm{ft}(12 \mathrm{~m})$. The outside turning radius is $101 \mathrm{ft}(31 \mathrm{~m})$. The transporter system utilizes prime movers (tractors) on each end enabling the transporter to be pushed into the disposal trench while loaded and positioned so the melter can be unloaded onto a platform similar to that utilized at the facility melter staging area. The facility utilizes a platform with Teflon rails and a motorized system to drag the melter on the rails horizontally from the facility or facility staging area platform onto the transporter. Once unloaded, movement of the transporter is accomplished by pushing or pulling it out of the trench.

The naval reactor compartment transporter may require some modification to accommodate the two different melters due to the size and weight difference (HLW melter weighs approximately 400 tons, LAW melter weighs approximately 810 tons). In addition, modifications will be needed to accommodate use of the facility rail system and the use of a rail system on the platform in the disposal trench.

3.3.1.4 Naval Reactor Compartment Transporter Modifications. The one-time cost for modification of the transporter is projected to be approximately $\$ 900 \mathrm{~K}$ to complete. The approximate schedule and approximate costs for modification, based upon efforts on the Hanford Site of similar complexity and similar level of quality assurance and safety levels, are broken down as follows:

- 1 year to complete modifications (prior to initial transport)

- $\$ 100 \mathrm{~K}$ for design modifications

- $\$ 150 \mathrm{~K}$ for safety basis analysis and safety basis documentation

- $\$ 100 \mathrm{~K}$ for procurement of materials and/or fabrication

- $\$ 500 \mathrm{~K}$ for fit up and actual modification of the transporter (approximately 50 tons of material at $\$ 5.00 / 1 \mathrm{~b}$ )

- $\$ 50 \mathrm{~K}$ for oversight, including safety and other organizations.

The existing transporter is capable of transporting the 810-ton load. The grade limit suitable for transport into the disposal trench is approximately $5 \%$, similar for entry into the naval reactor compartment trench.

The existing transporter can be utilized on current Hanford Site paved roads and/or bladed gravel roads since it has rubber tires and weight is distributed using multiple axles. The velocity of transport will be up to $5 \mathrm{mph}$. If transfer lines are crossed and/or it is deemed that strengthening of existing roads is needed, an evaluation will be done on a case by case basis. Upgrade of a 
roadway from the Vitrification Plant to the proposed disposal trench at the unused northwest corner of the 218-E-12B Burial Grounds (a distance of approximately $1.7 \mathrm{mi}$ ) will cost approximately $\$ 645 \mathrm{~K}$ to complete (assumes a window of 60 days to complete). This assumes repaving and widening the road (12th Street) to a minimum of $24 \mathrm{ft}$, with 3 - $\mathrm{ft}$ shoulders. This estimated cost was developed based upon recent upgrades to roadways within the Hanford Central Plateau.

\subsubsection{Option 2-Use of the Vitrification Plant Facility Transporter}

Under this option, the transporter used for moving melters within the vitrification facility will also be used to transport the melters to the disposal trench.

The drawings for the facility transporter are still preliminary. The facility transporter is designed to mate up with the facility from the side to accommodate loading of the HLW melter, and from the front/rear for LAW melter. The melter inside the over pack may be dragged onto the facility transporter horizontally using a motorized system. Note that there are currently no pick points to lift either the HLW or LAW melter onto the transporter. The melter is dragged onto the facility transporter via a rail system mated up to the facility (same height). The transporter must be able to adjust in height approximately $12 \mathrm{in}$. to accommodate the melter load. In addition, the transporter deck is intended to be fitted with an additional deck used when transporting the HLW melter.

The total length of the transporter system including the prime movers is approximately $152 \mathrm{ft}$ $(47 \mathrm{~m})$. The designed transporter is $42 \mathrm{ft}(13 \mathrm{~m})$ long by $24 \mathrm{ft}(8 \mathrm{~m})$ wide by $6 \mathrm{ft}(2 \mathrm{~m})$ high and weighs approximately 38 tons. The transporter is an 8-to-10-line system that is designed to be pushed or pulled (possibly from either end) by a multiple-axle prime mover. The inside turning radius is assumed to be approximately $15 \mathrm{ft}(5 \mathrm{~m})$. The outside turning radius is assumed to be approximately $40 \mathrm{ft}(13 \mathrm{~m})$. The velocity of transport is $3 \mathrm{mph}$.

The grade limit for transport of the HLW melter is $3 \%$. The grade limit for transport of the LAW melter is $2 \%$ or less. These grade limits would have to be applied to entry of the disposal trench. This could increase the disposal trench foot print and costs for design and construction of the disposal trench.

The facility transporter should be able to be utilized on current Hanford Site paved roads and/or bladed gravel roads since it has rubber tires and weight is distributed using multiple axles. If transfer lines are crossed and/or it is deemed that strengthening of existing roads is needed, an evaluation will be done on a case by case basis. Upgrade of a roadway from the Vitrification Plant to the proposed disposal trench at the unused northwest corner of the 218-E-12B Burial Grounds (a distance of approximately $1.7 \mathrm{mi}$ ) will cost approximately $\$ 645 \mathrm{~K}$ to complete (assumes a window of 60 days to complete). This assumes re-paving and widening the road (12th Street) to a minimum of $24 \mathrm{ft}$ with 3-ft shoulders.

The storage platform in the disposal trench could be designed to accommodate transloading the melters onto the platform via a similar motorized system. The disposal trench platform would 
mate up to the transporter for transloading. Cost figures are currently unavailable for the facility transporter system due to legal concerns associated with the vitrification contract. It is, however, assumed that utilization of this transporter, including maintenance costs would be substantially lower over the life time of the project compared to duplicating the cost in leasing or procurement of a second transporter for movement of the melters from the facility staging area to the disposal trench.

\section{Cost Summary for Option 2 - Use of Vitrification Plant Transporter}

\begin{tabular}{|l|r|r|}
\hline Item & Cost (\$) & Cost (\$) \\
\hline Shipment Cost & & 40,000 \\
\hline$\bullet \quad$ Personnel - Hanford & 40,000 & \\
\hline & & \\
\hline Transporter Procurement & & $2,100,000$ \\
\hline$\bullet \quad$ Transporter & $1,500,000$ & \\
\hline$\bullet \quad$ 2 Prime Movers & 500,000 & \\
\hline$\bullet \quad$ Delivery to Hanford & 100,000 & \\
\hline & & \\
\hline Roadway Modificatons & & 645,000 \\
\hline & & \\
\hline Total & & $\mathbf{2 , 7 8 5 , 0 0 0}$ \\
\hline
\end{tabular}

The approximate schedule and cost for procurement of the transporter is as follows.

3.3.2.1 Facility Transporter Procurement Schedule. Procurement and delivery prior to initial transport will take 1 to 2 years to complete. This will be done by the Vitrification Contractor and the transporter will be ready to use when the first spent/failed melter is generated.

3.3.2.2 Facility Transporter Procurement Cost. This cost breakdown is as follows:

- Transporter approximately $\$ 1,500 \mathrm{~K}$

- Two prime movers approximately $\$ 500 \mathrm{~K}$

- Delivery to Hanford approximately $\$ 100 \mathrm{~K}$

These costs will be incurred by the Vitrification Contractor no matter which transporter option is selected for the spent/failed melters.

3.3.2.3 Facility Transporter Shipment Schedule. This schedule will be as follows:

- 1 to 2 days per shipment

- Planning phase (including equipment mobilization) 30 days prior to transport

- 30 days for demobilization. 
3.3.2.4 Facility Transporter Shipment Cost. $\$ 40 \mathrm{~K}$ of Hanford Site cost will be for engineering, training of personnel in transporter operations, crafts, labor, and other support personnel and systems.

\subsubsection{Option 3-Use of a Leased Transporter Other Than the Transporter Used for Naval Reactor Compartments}

Under this option, the transporter and ancillary equipment are leased equipment other than the naval reactor compartment movements.

Transporter equipment available for use would be similar to the equipment used to transport the naval reactor compartments. The total length of the transporter system including the prime movers is approximately $194 \mathrm{ft}(59 \mathrm{~m})$. The transporter would carry 16 lines of tires with a length of $84 \mathrm{ft}(26 \mathrm{~m})$ by $24 \mathrm{ft}(8 \mathrm{~m})$ wide by $4 \mathrm{ft}(1.2 \mathrm{~m})$ high. The inside turning radius would be $30 \mathrm{ft}(10 \mathrm{~m})$. The outside turning radius would be $80 \mathrm{ft}(25 \mathrm{~m})$. Removal of the melter from the transporter would be accomplished utilizing a modified transporter platform and motorized system. A similar system is needed to drag the melter onto the rails of the transporter and off the transporter onto the disposal platform.

Cost Summary for Option 3 - Use of a Leased Transporter

\begin{tabular}{|l|r|r|}
\hline Item & Cost (\$) & Cost (\$) \\
\hline Shipment Cost & & 640,000 \\
\hline$\bullet \quad$ Transporter & 278,000 & \\
\hline$\bullet \quad$ Tractors & 42,000 & \\
\hline$\bullet \quad$ Personnel - Contractor & 390,000 & \\
\hline$\bullet \quad$ Personnel - Hanford & 30,000 & \\
\hline & & \\
\hline Transporter Modifications & & 900,000 \\
\hline$\bullet \quad$ Design Modifications & 100,000 & \\
\hline$\bullet \quad$ Safety Basis & 150,000 & \\
\hline$\bullet \quad$ Procurement & 100,000 & \\
\hline$\bullet \quad$ Fit-up/Modifications & 500,000 & \\
\hline$\bullet \quad$ QA/Oversight & 50,000 & \\
\hline & & \\
\hline Roadway Modificatons & & \\
\hline & & \\
\hline Total & & $\mathbf{2 , 1 8 5 , 0 0 0}$ \\
\hline
\end{tabular}

3.3.3.1 Leased Transporter Shipment Schedule. Planning and mobilization for each campaign will commence 30 days prior to transport. Note that this is worst case. Mobilization could take less time (as little as two weeks if equipment was available). More than one melter can be moved in a campaign. It is estimated that each melter will require that the transporter be 
dedicated for approximately one week, similar to the naval reactor compartments. Actual movement of the melter from the Vitrification Plant or storage area near the Vitrification Plant to the disposal trench will take 1 day. Demobilization will take approximately 30 days for each campaign.

3.3.3.2 Leased Transporter Shipment Cost. Leasing dedicated equipment will cost approximately $\$ 640 \mathrm{~K}$ per shipment due to an additional $\$ 100 \mathrm{~K}$ mobilization and demobilization costs over and above that needed for the naval reactor compartment transporter system. Cost breakdown, with the same basis as Option 1, is as follows:

- $\$ 278 \mathrm{~K}$ for one transporter-includes cost for 60 days based on a schedule for mobilization, use, and demobilization)

- $\$ 42 \mathrm{~K}$ for two prime movers (tractors)-includes cost for 60 days based on a schedule for mobilization, use, and demobilization

- $\$ 290 \mathrm{~K}$ for service provider engineering, crafts, labor, and other support personnel and systems.

- $\$ 30 \mathrm{~K}$ of Hanford Site cost for engineering, crafts, labor, and other support personnel and systems - includes a planning phase of 30 to 60 days prior to transport.

3.3.3.3 Leased Transporter Modification. The cost for modification of the transporter to accommodate the loading and unloading system is projected to be an additional $\$ 900 \mathrm{~K}$ to complete which is consistent with Option 1 above.

Completion of modifications (prior to initial transport) will take 1 year.

3.3.3.4 Naval Reactor Compartment Transporter Logistics. Upgrade of a roadway from the Vitrification Plant to the proposed disposal trench at the unused northwest corner of the 218-E$12 \mathrm{~B}$ Burial Grounds (a distance of approximately 1.7 miles) will cost approximately $\$ 645 \mathrm{~K}$ to complete (assumes a window of 60 days to complete). This assumes re-paving and widening the road (12th street) to a minimum of $24 \mathrm{ft}$ with 3 - $\mathrm{ft}$ shoulders.

\subsubsection{Option 4-Procurement of a Dedicated Transporter System}

The transporter system would cost approximately $\$ 2,100 \mathrm{~K}$ with a cost of $\$ 1,500 \mathrm{~K}$ in maintenance over the project lifetime. This option potentially doubles the cost projected for use of the facility transporter (Option 2) since two transporters would be needed for movement of the melters (the facility transporter and the transporter for movement to the disposal trench).

Personnel would need to be trained in operations and maintenance activities to ensure the operability of the transporter system, in addition to operation and maintenance of the facility transporter. All design requirements for the transporter system must be consistent with the 
facility and disposal trench platforms. The transporter, training program, and maintenance program must be in place prior to initial operation of the transporter system.

Cost Summary for Option 4 - Use of a Dedicated Transporter

\begin{tabular}{|l|r|r|}
\hline Item & Cost (\$) & Cost (\$) \\
\hline Shipment Cost & & 40,000 \\
\hline$\bullet \quad$ Personnel - Hanford & 40,000 & \\
\hline & & \\
\hline Transporter Procurement & & $3,600,000$ \\
\hline$\bullet \quad$ Transporter & $1,500,000$ & \\
\hline$\bullet \quad$ Transporter Maintenance & $1,500,000$ & \\
\hline$\bullet \quad$ 2 Prime Movers & 500,000 & \\
\hline$\bullet \quad$ Delivery to Hanford & 100,000 & \\
\hline & & \\
\hline Roadway Modificatons & & $\mathbf{6 4 5 , 0 0 0}$ \\
\hline & & \\
\hline Total & & $\mathbf{4 , 2 8 5 , 0 0 0}$ \\
\hline
\end{tabular}

3.3.4.1 Dedicated Transporter Shipment Schedule. The schedule will be as follows:

- 1 to 2 days per shipment

- Planning phase (including equipment mobilization) 30 days prior to transport

- 30 days for demobilization.

3.3.4.2 Dedicated Transporter Shipment Cost. $\$ 40 \mathrm{~K}$ of Hanford Site cost will be for engineering, training of personnel in transporter operations, crafts, labor, and other support personnel and systems.

\subsubsection{Melter Transporter Strategy}

Option 1 may be the most viable solution to be utilized for melter transport to the disposal trench based on existing information and due to the availability of the existing transporter and close proximity of the transporter service provider. Capabilities of this transporter are known with the exception of details associated with modification to the transporter for melter loading and unloading; e.g., Motorized system for dragging the melter to and from the transporter, platform modifications. The cost is within the range established for the cases of use of the facility transporter and procurement of a dedicated transporter for movement to the disposal trench..

Option 2 may prove to be the most desirable option over all if preliminary designs, budget, and schedule are adequately determined to establish the need for only one transporter system.

In addition, Option 2 would be the most desirable option if no requirement is imposed to stage the transporter in the facility area; i.e., transport melters directly to the disposal trench, and no 


\section{RPP-7094 REV 0}

requirement establishes a need to operate and maintain the facility transporter within the facility boundaries due to design or scheduling concerns.

Option 3 is comparable to Option 1 with the same operating parameters. Additional cost for mobilization and demobilization makes this option less desirable than Option 1.

Option 4 should not be considered unless parameters for new contractor require a second dedicated transporter system.

STRATEGY: This is a rough estimate based upon experience with the transport vehicle used to transport the naval reactor compartments. If cost were the only factor, then Option 2 would be the selected option, however, because there is a significant opportunity for cost savings, and because the transport vehicle is a vital component to completing the overall mission of disposing of the spent/failed melters, it is recommended that an AGA be performed in FY 2001 to refine and validate this option. 


\subsection{DISPOSAL}

\subsection{SUMMARY}

This section discusses strategies for disposal of failed melter packages including melter disposal trench design, trench capacity and loading, and trench leachate disposal options. The disposal trench will be used for failed melters from both the low-activity waste (LAW) and high-level waste (HLW) vitrification processes. The preferred trench location is the unused west section of the 218-E-12B burial ground in 200 East Area, as this is closest to the proposed vitrification plant site. Alternatively, there are several possible trench sites in the 200 West Area, although locating the trench in $200 \mathrm{~W}$ would significantly lengthen the failed melter transport route and could provide greater challenges for leachate disposal.

The baseline trench design is similar to the naval reactor compartment disposal trench, with a rail off-loading system. The initial trench module will accommodate failed melters from Phase I vitrification, with expansion capability for future modules. Washington Administrative Code (WAC) 173-303-665 requires two liners and a leachate collection and removal system above and between the liners. This is the baseline strategy at present.

Three alternate trench design options are proposed. The first calls for an unlined melter disposal trench, which would require an exception from the WAC. The second option uses small leachate collection areas beneath each waste package to minimize leachate collection, with the melter package considered as the primary containment to limit the need for an overall trench liner. This option would likely require an exemption from the WAC as well. The third option sites the melter disposal trench in the 200 West Area.

As an alternative, the failed melter disposal trench could be designed as a multi-use trench to accept mixed low-level waste (MLLW) from onsite and offsite generators, with additional modules designated for MLLW. Impacts are increased trench size and additional leachate collection and storage needs.

Trench leachate will be treated at the 200 Area Liquid Waste Processing Facilities (LWPF). Leachate may be stored in holding tanks and will be transported to the 200 Area LWPF either by tanker truck, or by pumping through a pipeline. Options for melter disposal trench leachate handling are compared with existing leachate systems for the Mixed Waste Trench and the Environmental Restoration Disposal Facility (ERDF), both in 200 West Area, and with Project W-519, which will provide aqueous waste transfer lines from the vitrification facility to the 200 Area LWPF.

An Alternate Generation Analysis (AGA) is planned for FY 2001 to evaluate alternate trench configurations and leachate transportation options. 


\subsection{MELTER DISPOSAL TRENCH DESIGN}

The Melter Disposal Trench will be dedicated to both LAW and HLW melters in the same trench. Although final trench location can only be determined during final design to evaluate potential issues such as load bearing capacity and nearness of surface/ground water. At this time, the preliminary choice for the location of the Melter Disposal Trench is in the unused west section of burial ground 218-E-12B. Figure 1 details the 218-E-12B Burial Ground and potential location for the Melter Disposal Trench. This area is in the existing burial ground nearest to the proposed Vitrification facilities, thus minimizing transportation distances for the LAW and HLW melters. It is also near the 200 Area Effluent Treatment Facility (ETF), allowing leachate from the melter trench to be piped to the ETF for treatment.

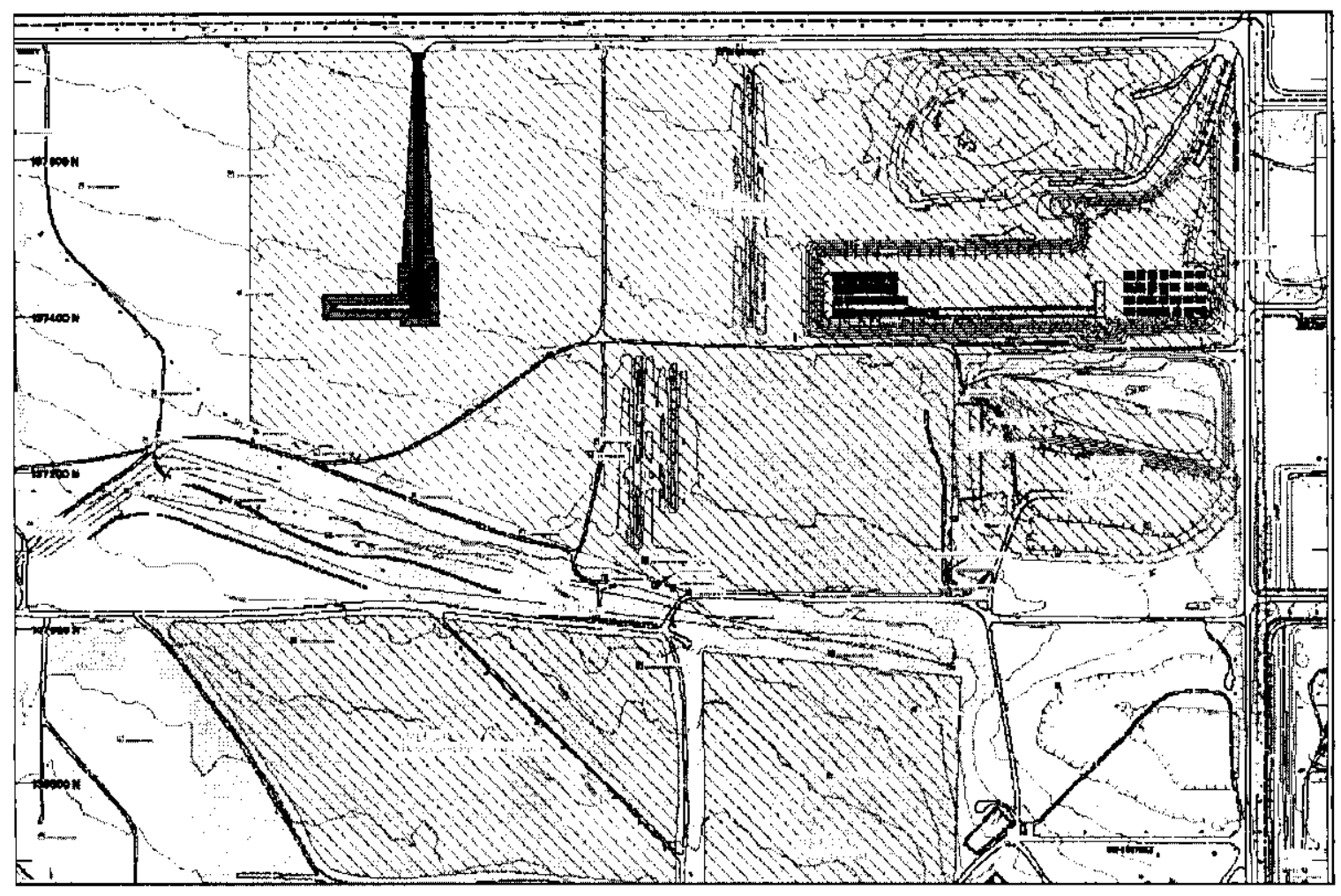

Figure 1. 218-E-12B Burial Ground and Potential Melter Disposal Trench Location.

There are several locations in the 200 West Area that could be identified for a Melter Disposal Trench. The impacts associated with a $200 \mathrm{West}$ area location include the significant relocation logistics of the spent and failed melters, costs for road improvements and cost for leachate transfer to the ETF by truck (see Section 6.5). The design of the Melter Disposal trench would not be affected by any particular location. 


\subsubsection{Baseline Trench Details}

The Melter Disposal Trench baseline design is similar to the 218-E-12B Burial Ground Trench 94 (Submarine Trench). The baseline design includes an off-loading rail system similar to the 218-E-12B Burial Ground Trench 94 (Submarine Trench). The large waste packages containing spent and failed melters will be off-loaded from the transport vehicle to a rail interface. A rail system is necessary primarily due to the estimated weight of the grouted package.

The Melter Disposal Trench will be constructed to include an access ramp, a trench alignment vestibule, an unloading area and one module sized to store the estimated number of spent and failed Phase 1 melters. There will be an entrance/expansion used for the backward ingress and forward egress from $12^{\text {th }}$ Street into the trench to allowing for alignment of the transport vehicle. It is assumed that the ramp grade and the slope of the side cuts will be the same as those of Trench 94. The trench floor will be at a depth to accommodate the liner, support base and the height of the waste package. For the purposes of developing costing information, a $5 \mathrm{~m}$ thick closure cover will be used. Specific closure plan information will be developed at a later date. Closure costs are not included in this document.

The alignment vestibule must be at least two times the length of the selected transport. At this time, for the purposes of developing a baseline strategy, it is assumed that the waste packages will be off-loaded from the side of the transport vehicle to a rail system. A larger vestibule area can be designed to accommodate off-loading from the side and back of the transporter if necessary depending on the constraints of the transporter. Figure 2 details the general layout of the Melter Disposal Trench.

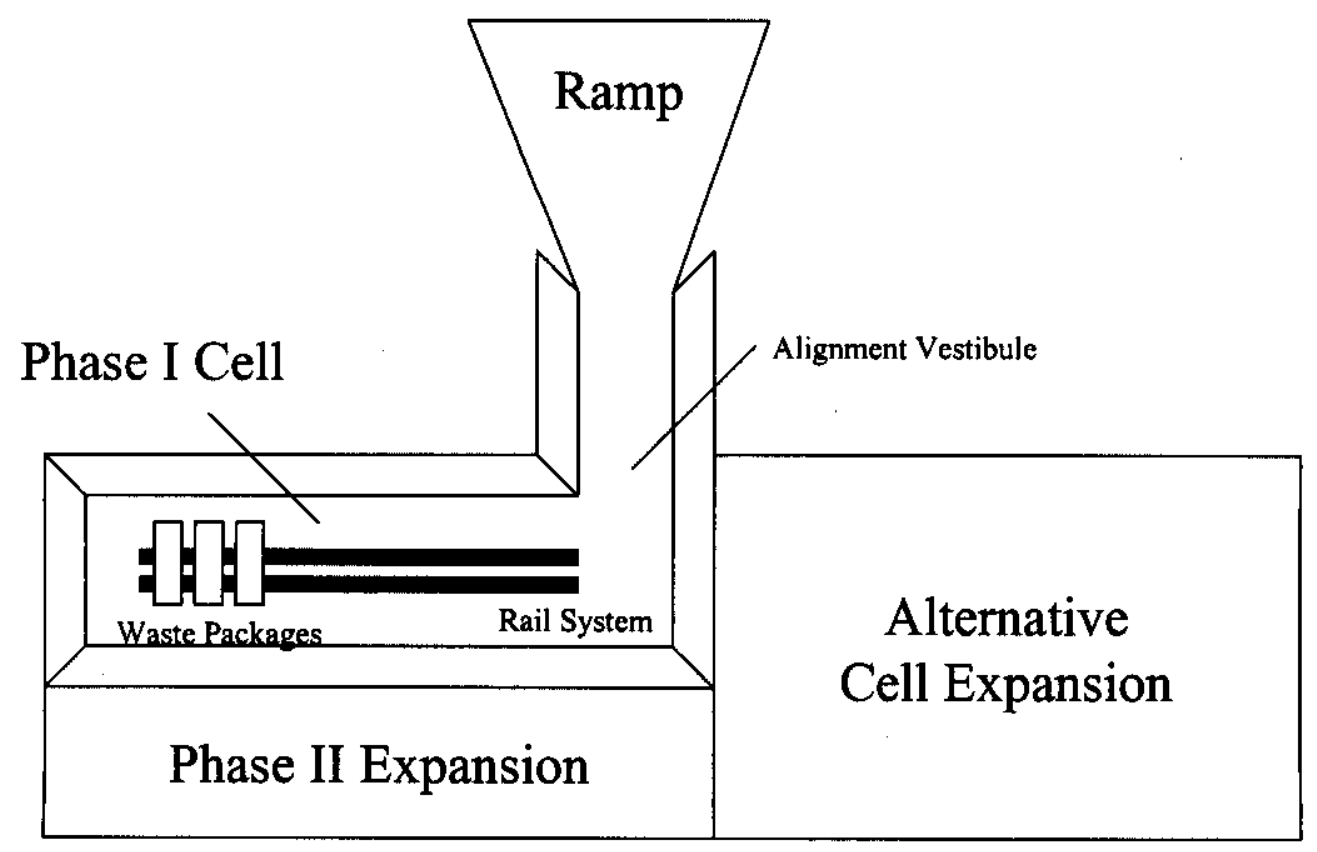

Figure 2. General Layout of Baseline Melter Trench. 
The size and construction of the Melter Trench rail system will be similar to that of the Trench 94 rail system. The rail system must be designed to interface with the Vitrification facility transporter and the transport vehicle used to relocate the spent and failed melters to the burial trench. The waste container would need to be designed to interface with the rail system.

Each waste package will be off-loaded to the rail system and pulled on rollers along the rail. Each trench module will have an independent rail system. It is assumed that each module will contain a rail system capable of storing the number of melters associated with Phase 1 . The waste package will be rolled to its designated position via a cable pulley system and Prime Mover similar to the Trench 94 system.

The waste packages will be off-loaded and repositioned to the end of the rail section in the Phase 1 module to allow for continual additions of Phase 1 spent and failed melters. The trench will remain open until the end of the campaign. The trench will be expanded to accommodate the estimated number of melters for Phase 2.

The trench will be expanded by construction of additional modules. The trench can be expanded by either lengthening the alignment vestibule and constructing additional trenches to the south of the Phase I module or constructing additional trenches across from the Phase I module as depicted in Figure 2. Additional modules constructed across the alignment vestibule would be most effective if the transport vehicle was designed to off-load the waste packages from each side. A larger alignment vestibule could be required depending on the transport vehicle selected. See Figures 3 and 4 for a comparison of the Phase I trench with a proposed expansion to allow for Phase II waste.

A berm must surround the level section of the trench modules with a removable end section for loading. The side slopes of the trench will begin immediately at the outside of the berm perimeter. The liner can be extended for future expansion similar to work currently being done at the ERDF.

Based on WAC173-303-665, two or more liners and a leachate collection and removal system above and between such liners is required. The liner system must be of sufficient strength and thickness to prevent failure under the pressures exerted by overlying wastes, waste cover materials, and by any equipment used at the landfill. The liner system must include a top liner designed and constructed of materials to prevent the migration of dangerous constituents into this component during the active life and post-closure care period. The lower component must be designed and constructed of materials to minimize the migration of dangerous constituents if a breach in the upper component were to occur.

A double-liner system similar to the ERDF facility has been established as the baseline strategy at this time. The floor liner section would likely contain a primary and secondary HDPE geomembrane within layers of drainage gravel, and geotextile cushions. 


\section{RPP-7094 REV 0}

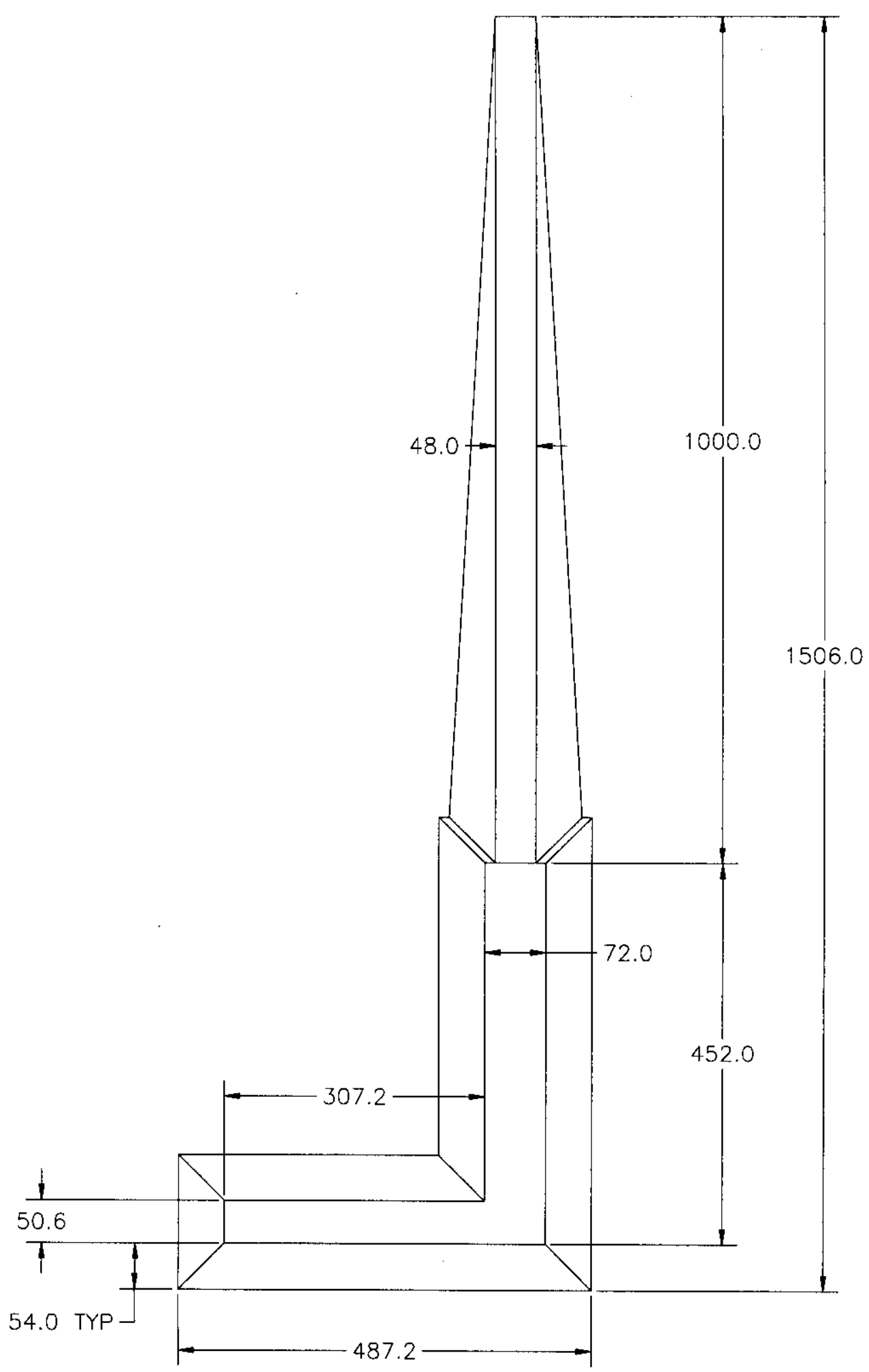

Figure 3. Phase I Trench Layout. 


\section{RPP-7094 REV 0}

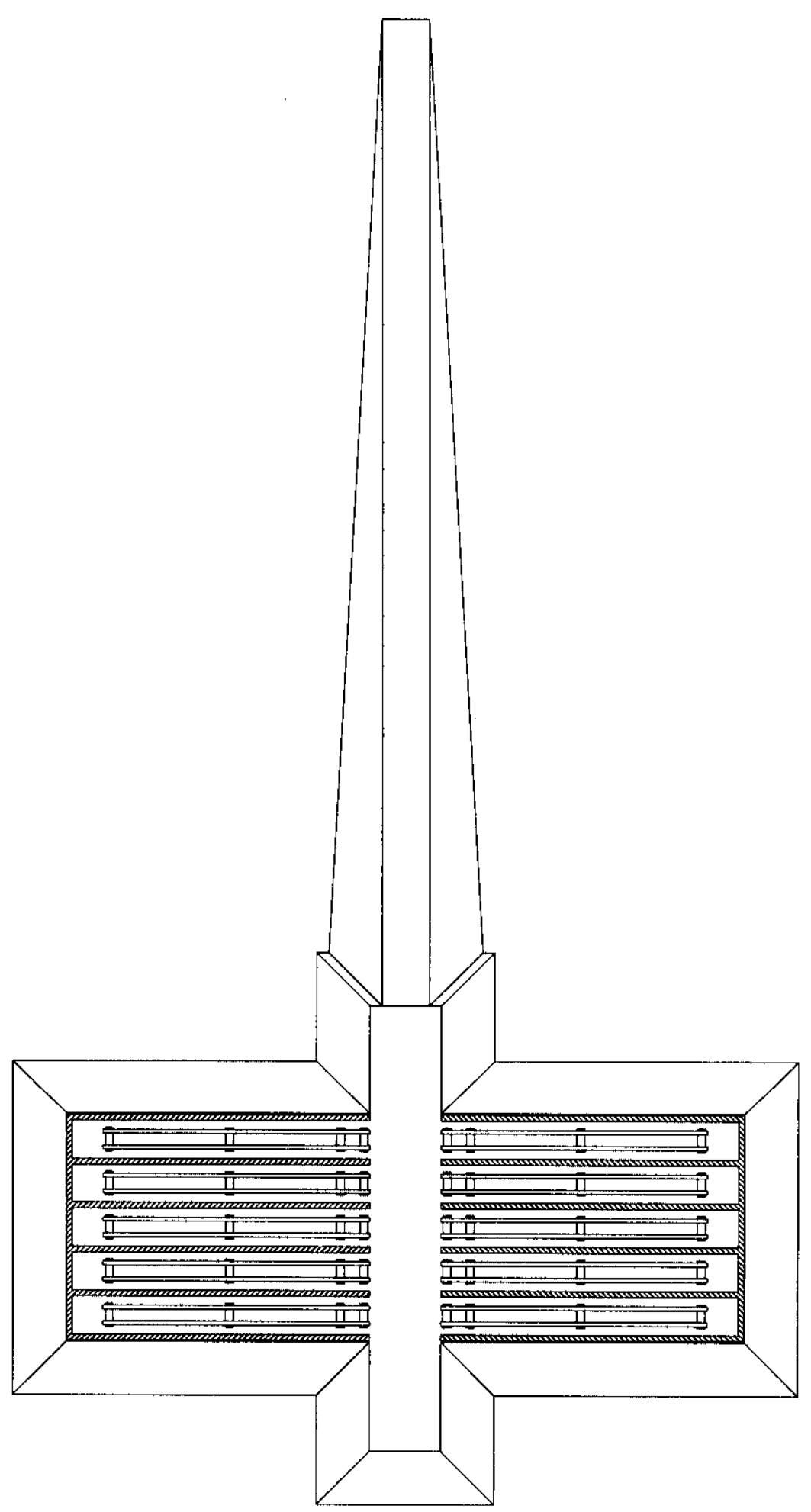

Figure 4. Phase II Trench Layout. 
The liner system must be of sufficient strength and thickness to prevent failure under the pressures exerted by overlying wastes, waste cover materials, and by any equipment used at the landfill. The design of the liner system would need to consider the heavy weight of the waste package. Modifications to the ERDF liner design could include the incorporation of soil stabilization or load dispersion techniques. The liner system should be designed in such a way to minimize the volume of leachate collected. This issue is discussed further in the Alternative Options section.

The leachate collection and removal system immediately above the top liner must be designed, constructed, operated and maintained to collect and remove leachate from the landfill during the active life and post-closure care period. The leachate collection and removal system between the liners is also a leak detection system. This leak detection system must be capable of detecting, collecting and removing leaks of dangerous constituents at the earliest practicable time through all areas of the top liner likely to be exposed to waste or leachate during the active life and postclosure care period.

At final closure of the landfill or upon closure of any module, the owner or operator must cover the landfill or module with a final cover designed and constructed to provide long term minimization of migration of liquids through the closed landfill, function with minimum maintenance, promote drainage and minimize erosion or abrasion of the cover, accommodate settling and subsidence so that the cover's integrity is maintained. For the purpose of developing this baseline strategy, a soil cap of $5 \mathrm{~m}$ will be used.

\subsubsection{Alternative Options}

Three options were evaluated relative to trench design.

4.2.2.2 Option 1-Unlined Melter Disposal Trench. As an alternative, a request for exemption from lined trench requirements can be obtained similar to the 218-E-12B Burial Ground Trench 94 (Subtrench) exemption. This exemption alleviated the requirement for a double lined trench with leachate collection system. The exemption would need to be prepared and submitted as part of the Part B permitting process. This exemption would have significant impact to the design of the Melter Burial Trench, in regard to cost, schedule, and maintenance requirements.

This option reduces the costs of design and construction of the trench considerably by alleviating the requirement for an expensive liner and leachate collection system. In addition, the cost of maintenance, operations and module expansion would also be reduced. An exemption would reduce construction cost of Phase I by approximately $26 \%$. Cost savings would be significant for future expansion of the Melter Disposal Trench.

STRATEGY The design of the Melter Disposal Trench should proceed concurrently with the exemption process to reduce the impacts to the project schedule. If the exemption is approved, the requirements of the leachate system and liner can be removed from the design. 
4.2.2.2 Option 2-Minimization of Leachate Collection. As an alternative to the baseline design small lined collection areas can be incorporated under each waste package to minimize leachate collection. These collection areas can be designed as steel trays or concrete basins under each waste package as part of the rail system. The minimal volume of leachate from each basin or tray would be collected and transferred to the leachate collection tank for further transfer to the ETF.

This option would reduce the amount of collected leachate considerably and remove the need for a costly subsurface liner and collection system for the entire Melter Disposal Trench. In addition, these trays or basins would be constructed to handle the weight of the waste package which at this time is a significant uncertainty in the design of a liner system similar to that constructed at the ERDF.

In order to meet the requirements for a landfill, a liner system must be incorporated as part of the tray or basin. Alternatively, the waste package could be considered as primary containment, limiting the need for any additional liners. This would likely require an exemption similar to that discussed in Section 4.2.2.1, Option 1.

\subsubsection{Option 3-200 West Area Melter Disposal Trench.}

There are several locations in the 200 West Area that could be identified for a Melter Disposal Trench. The impacts associated with a 200 West area location include the significant relocation logistics of the spent and failed melters, costs for road improvements and cost for leachate transfer to the ETF. The Melter Disposal Trench Leachate Handling Strategy discusses alternatives for leachate transfer from a potential 200 West Area site.

The impacts associated with a $200 \mathrm{~W}$ Area location on the design of the Melter Disposal Trench are minimal. Impacts to permitting and schedule would also be minimal.

\subsubsection{Melter Design Strategy}

a. Option 1, a liner exemption, would be the most cost effective modification to Melter Disposal Trench baseline. An exemption would significantly reduce the costs of design, construction and operation of the trench. Based on input from the baseline cost estimate, an exemption would reduce the construction cost of Phase I by approximately $26 \%$. Cost savings would be significant for future expansion of the Melter Disposal Trench.

Although an exemption was granted for 218-E-12B Burial Ground Trench 94 (Subtrench) it is difficult to determine the likelihood of an exemption for the Melter Disposal Trench. This strategy suggests that an Alternate Generation Analysis (AGA) evaluate the possibility of an exemption for the proposed trench. In addition, the design of the Melter Disposal Trench should proceed concurrently with the exemption process to reduce the impacts to the project schedule. If the exemption is approved, the requirements of the leachate system and liner can be removed from the design. 
b. Option 2, or some derivative of this option, could be incorporated in the baseline design if a liner exemption is not pursued or is rejected. Small lined or unlined collection areas incorporated under each waste package would effectively minimize leachate collection. These collection areas can be designed as a steel tray or concrete basin under each waste package as part of the rail system. This option would reduce the amount of collected leachate considerably and remove the need for a costly sub-surface liner and collection system for the entire Melter Disposal Trench.

STRATEGY: Because there are so many variables relative to trench design, and because trench design and location can have such a huge impact on transportation costs and leachate management costs, it is recommended that an AGA be performed in FY 2001 to determine the usefulness of pursuing any or all of these options. Trench design based on the baseline strategy presented above or alternatives chosen during the AGA should begin as soon as appropriate. Such alternative may include a parallel path of developing the lined trench design with parallel efforts to obtain an exemption to the liner requirements.

\subsection{MELTER DISPOSAL TRENCH CAPACITY/LOADING}

As an alternative to the baseline trench design and options presented in Section 4.1 the Melter Disposal Trench can be designed as a multi-use trench accepting MLLW from onsite and offsite generators. The trench could be expanded with additional modules specifically designated for MLLW. Impacts associated with this option include an increased size of the trench, a potential second dedicated leachate collection and storage system and additional design, construction, and operational costs.

STRATEGY: Although it is a relatively simple matter to design the Melter Disposal Trench with sufficient capacity to dispose of the Phase I melters, there could also be a significant potential for savings to the DOE if the trench can be used for other waste. Hence, an AGA is recommended, commencing in $F Y 2001$, to address the issue of whether waste other than melters can be disposed of in the same trench, and if so, how.

\subsection{MELTER DISPOSAL TRENCH LEACHATE}

Leachate produced at the melter disposal trench will be processed at the 200 Area Liquid Waste Processing Facilities (LWPF). Options exist to truck the leachate to the LWPF similar to that used in the existing mixed waste trenches (218-W-5, Trench 34), or to provide a direct-tie pipeline between the melter disposal trench and the LWPF, as is the case with leachate produced at ERDF. Cost estimates for leachate piping are obtained by comparison with Project W-519. A more complete discussion of the LWPF and the options for managing leachate is included in Appendix A.

\subsubsection{Area Liquid Waste Processing Facilities (LWPF)}


The Liquid Effluent Retention Facility (LERF) consists of three RCRA-compliant surface impoundments for temporarily storing process condensate from the 242-A Evaporator and other liquid wastes. The LERF provides equalization of the flow and $\mathrm{pH}$ of the feed to the ETF. Each LERF basin has a capacity of 7.8 million gallons. Spare capacity is maintained equal to the volume of one LERF basin as contingency in the event a leak should develop in an operational basin. Included in LERF are the dedicated transfer lines and a valve manifold that contain and route liquid wastes to one of the three basins. The LERF began operation in April 1994 and has a 20-year design life.

Liquid wastes are treated in the ETF to remove toxic metals and radionuclides, and destroy organics. The ETF treatment process constitutes Best Available Technology (BAT) and includes $\mathrm{pH}$ adjustment, filtration, ultraviolet light/peroxide (UV/OX) destruction of organics, reverse osmosis (RO), and ion exchange. Treatment capacity of the ETF is $150 \mathrm{gpm}$. Storage tanks allow for holdup of the treated effluent to allow verification that the waste has been treated to acceptable levels prior to discharge. The treated effluent is discharged under the WAC 173-216 State Waste Discharge Permit number ST 4500 to a State-Approved Land Disposal Site (SALDS) located north of the 200 West Area. The ETF began operation in December 1995 and has a 30-year design life.

Operation of the ETF is subject to the requirements contained in DOE Orders, and is regulated under permits and approvals issued by the Washington State Department of Ecology (Ecology), Washington State Department of Health (WDOH), and the U.S. Environmental Protection Agency (EPA). The ETF can treat liquid wastes regulated under RCRA, CERCLA, or DOE Orders.

The 291 Load-In Facility at the ETF allows liquid wastes to be received via tanker trucks and waste drums from other projects. A cross-site transfer system is used to transfer groundwater from the 200-UP-1 operable unit and ERDF leachate to the ETF for treatment.

Liquid wastes containing greater than $1 \%$ solids may be required to be filtered through a 5 micron (nominal) filter before receipt at the ETF. Additional filtration could be required if a significant amount of suspended solids remains after 5 micron filtration.

\subsubsection{Tank Trailers}

The Waste Management Project has tank trailers available for use by a generating unit such as the melter disposal trench. The following tank trailers are available for transporting liquid wastes:

- Beall tank trailers (2) - 8,000-gal capacity

- Polar tank trailers (3) - 5,000-gal capacity

- Walker tank trailer (1) - 5,000-gal capacity

- Superior tank trailer (1) - 1,000-gal capacity.

All the tank trailers are top fill design. The Beall tank trailers were recently purchased, and have a sloped bottom and drain to facilitate cleaning. 


\subsubsection{Mixed Waste Trench Leachate}

The Mixed Waste Trench (218-W-5, Trench 34) is a RCRA-compliant Subtitle C landfill; e.g., double-lined trench with leachate collection and removal system, and currently is operating under interim status. Trench 34 is used to dispose of mixed waste that has been treated to meet Land Disposal Restriction requirements. The collected leachate is managed as a mixed waste multi-source leachate (F039) derived from listed dangerous waste numbers F001 through F005.

Leachate from the Mixed Waste Trench is temporarily stored in a 10,000-gal aboveground tank. The tank is surrounded by a concrete berm that is epoxy coated and has an HDPE liner. A concrete pad adjacent to the tank provides access for tanker trucks. The Beall tank trailers are used to transfer the Mixed Waste Trench leachate to the 291 Load-In Facility at the ETF. Capacity of the Beall tank trailers is 8,000 gal, but the volume of leachate transferred is procedurally limited to 7,000 gal.

A larger tank is needed for storing leachate. The leachate is allowed to be stored for up to 90 days, but because the storage tank is undersized it must be emptied quickly to make space available should more leachate be generated. A 24-hour, 25-year storm could possibly cause the allowable 1-ft hydrostatic head on the trench liner to be exceeded because the leachate cannot be removed quickly enough. It is estimated that a 24 -hour, 25 -year storm could produce 127,000 gal of leachate at the Mixed Waste Trench (RFSH 1996). A separate report estimated the average annual leachate production to be 155,000 gal and the peak daily leachate production at 110,000 gal (WHC 1994). The storage tank capacity is $10,000 \mathrm{gal}$, and it is possible to hold $10,000 \mathrm{gal}$ in the trench at just below $1-\mathrm{ft}$ hydrostatic head. Larger storage tanks may also reduce sampling costs. Leachate could be temporarily stored in tank trailers in an emergency.

A filter system is recommended for the leachate to prevent solids from getting in the tank trailers.

Before leachate transfers to the ETF can begin, the generator is required to provide physical, chemical, and radiological characterization data and complete a waste profile sheet. The generator is later required to perform verification sampling. Paperwork for each transfer includes a shipping manifest, which identifies the radioactive and hazardous constituents in the liquid waste, and the quantities.

\subsubsection{Assumptions}

Some assumptions are necessary to complete the analysis of Melter Disposal Trench leachate analysis.

4.4.4.1 General. The Melter Disposal Trench design will include: leachate collection system, leachate removal pump, leachate temporary storage tank, leachate transfer pump, leachate filter system. 


\section{RPP-7094 REV 0}

The Melter Disposal Trench leachate will be acceptable for treatment at the ETF.

4.4.4.2 Tank Truck Option. The 291 Load-in Facility at the ETF will be available to receive the Melter Disposal Trench leachate.

4.4.4.3 Pipeline Option. The LERF will be available to receive the Melter Trench leachate.

\subsubsection{Leachate Strategy}

STRATEGY: An AGA is planned for FY 2001 that will evaluate alternative trench configurations. The study should address transportation of the leachate from the trench to the ETF. Life-cycle cost will be an important consideration in determining whether the leachate is transferred by tanker truck or pipeline. (Other factors include public and worker safety, environmental risk, regulatory compliance, and operability/maintainability of the leachate transfer system.)

Costs for transporting the leachate will be driven by the location and size of the trench.

Location of the trench determines the distance the leachate must be transported, while size of the trench determines the volume of leachate. The location chosen for the trench will be based upon proximity to waste streams and site characteristics. The size of the trench will depend on whether the trench is only for failed melters from the vitrification facility, or whether a large multi-use trench is needed to accommodate the waste disposal requirements of other site cleanup activities.

STRATEGY: For the tanker truck option, plan to use the existing Beall tank trailers to transfer the Melter Disposal Trench leachate. Because of their larger size, the volume of leachate that can be transferred each trip is greater for approximately the same cost per trip. The smaller Polar tank trailers and the Walker tank trailer are available as backups if needed.

If a large multi-use trench in the 200 West Area is planned, then evaluate if tanker trucks can reasonably accommodate the amount of leachate that may be produced, particularly during a 24-hr, 25-yr storm. A cross-site pipeline for transferring leachate to the LERF may be justifled (relative to large volume RCRA-compliant storage tanks for leachate awaiting transfer by tanker truck). A pipeline from 200 West Area to the LERF should consider tying in the leachate from the Mixed Waste Trench. Operating costs may be reduced by eliminating tanker truck transfers of the Mixed Waste Trench leachate. Concerns about insufficient leachate storage space would also be resolved. 


\subsection{PROGRAMMATIC}

\subsection{SUMMARY}

This section covers programmatic issues that include melter disposal trench RCRA permitting and other environmental documentation, as well as cost and schedule. Baseline assumptions include compliance of grouted failed melters with Land Disposal Restrictions as they are released from the vitrification facility.

Full RCRA compliance is recommended for the melter disposal trench. Significant issues with RCRA permitting include uncertainties in compiling supporting documentation for a Part B permit, reissuance of the Hanford Facility RCRA permit that expires in September 2004, the timing of Ecology rulings, unknowns such as chemical and physical characterization of the failed melters, and 200 Area Effluent Treatment Facility acceptance of the trench leachate, which may be designated as F039 waste.

Issues, options, and strategies are discussed for the following other environmental issues:

- NEPA/SEPA

- Cultural Resources and Ecological Compliance Reviews

- Environmental Monitoring

- Mitigation Action Planning

- Excavation Permitting

- DOE Acquisition/Environment, Safety and Health Management

- Air Permitting

- Water and Waste Water Management

- Radioactive Materials and Waste Management

- Hazardous Substances

- Hanford Site Solid Waste Acceptance Criteria.

Cost estimates for the above activities and a proposed schedule are also provided in this section.

\subsection{MELTER DISPOSAL TRENCH RCRA PERMITTING}

RCRA is a comprehensive program, implemented by EPA to ensure that hazardous waste will be treated, stored, and disposed of so as to minimize the present and future threat to human health and the environment. Ecology has been delegated authority by EPA to oversee an equivalent state program. Dual jurisdiction by EPA and Ecology continues for a few provisions (e.g., Land Disposal Restrictions [LDR] and corrective action).

The Melter Disposal Trench will accept grouted melters that have processed both LAW and HLW (separately) by vitrification. Because the melters carry the same listed waste codes as the Hanford tank waste (F001 through F005), the melters are subject to all the land disposal restrictions (LDR) that are imposed on listed waste. The leachate may potentially designate with 
waste number F039. The disposal unit will be subject to the landfill design requirements as specified in Title 40 Code of Federal Regulations (CFR) 264 Subpart N and WAC 173-303-665. The primary design features mandated by these regulations are the leachate collection system and trench liner system. The baseline assumptions include that the melters will be LDR compliant as they are released from the vitrification plant for transport and disposal.

The proposed location for the melter disposal trench is in the RCRA permitted Mixed Waste Disposal Unit. A final status Part B permit is expected to be in place, incorporated into the Hanford Facility (HF) Permit for the MWDU by December 2002. Under the baseline assumption trench design and other supporting data will be in the process of definition until after that date. Therefore, a class 3 modification to the HF Permit will be required. [In the event of a significant delay in finalizing the MWDU permit it may be possible to incorporate the melter disposal prior to incorporation of the permit into the HF Permit. Therefore, a class 3 modification to the HF permit would not be required. It is not anticipated that this scenario would either delay or accelerate the permitting process.]

Items supporting the Class 3 modification will be submitted to Ecology for approval (draft version) as they near completion. Items will need to be prepared or revised to address melter disposal. These, and other necessary activities, along with cost and schedule estimates, are shown in Table 1. A more detailed environmental requirements checklist is contained in Appendix F. The items are as follows:

- A revised Part A application

- The final design documents

- A construction Quality Assurance Plan

- A topographical map of the burial ground/trench facility as it will be built

- 9090 Test specification test results on the liner material and the liner (including leak-tests) as built

- A Response Action Plan for contingencies and leakage exceedance

- Waste Analysis Plan revision if necessary

- Building Emergency Plan revision if necessary

- Facility closure plan (after all waste is accepted); would be revised before implementing

- Groundwater monitoring plan, including installation requirements of any new monitoring wells, if required. 
Table 1. Cost and Schedule Estimates for RCRA Permitting Activities.

\begin{tabular}{|c|c|c|c|}
\hline Activity & $\begin{array}{c}\text { Contract } \\
\text { Cost }\end{array}$ & Resource & Duration \\
\hline RCRA Hazardous Waste Permit Modification & & $\begin{array}{l}\text { 0.8 FTE per year } \\
\text { (total } 6750 \text { hours) }\end{array}$ & 4.5 years \\
\hline Part B Development & & $\begin{array}{l}0.5 \mathrm{FTE} \\
(1830 \text { hours })\end{array}$ & 2 years \\
\hline \multicolumn{4}{|l|}{ Revise the MWDU Part A permit. } \\
\hline \multicolumn{4}{|l|}{$\begin{array}{l}\text { Provide input to the design activity. Review the final } \\
\text { design \& design report }\end{array}$} \\
\hline \multicolumn{4}{|l|}{ Provide input to the Construction Quality Assurance Plan } \\
\hline \multicolumn{4}{|l|}{$\begin{array}{l}\text { Interface with specification and acceptance tests on the } \\
\text { liner material ( } 9090 \text { test) }\end{array}$} \\
\hline \multicolumn{4}{|l|}{ Provide regulator interfacing for liner issues } \\
\hline \multicolumn{4}{|l|}{$\begin{array}{l}\text { Provide input to the site investigative report; review } \\
\text { report }\end{array}$} \\
\hline $\begin{array}{l}\text { Review the proposed topographic maps of the facility, to } \\
\text { be constructed }\end{array}$ & $\$ 5,000$ & & \\
\hline \multicolumn{4}{|l|}{$\begin{array}{l}\text { Provide input to the MWDU Response Action Plan; } \\
\text { (developed by MWDU/contract staff) }\end{array}$} \\
\hline \multicolumn{4}{|l|}{ Provide input to the Waste Analysis Plan } \\
\hline \multicolumn{4}{|l|}{ Provide input to the Building Emergency Plan } \\
\hline \multicolumn{4}{|l|}{$\begin{array}{l}\text { Provide input \& review the Groundwater Monitoring } \\
\text { Plan; (develop by PNNL }\end{array}$} \\
\hline Interface with construction of GW Wells (by contract) & $? ? ?$ & & \\
\hline \multicolumn{4}{|l|}{$\begin{array}{l}\text { Provide input/review of GW well tests; interface with } \\
\text { regulators }\end{array}$} \\
\hline \multicolumn{4}{|l|}{ Assemble Text } \\
\hline Part B Internal Review & & $\begin{array}{l}\text { 1.0 FTE } \\
(\sim 1830 \text { hours })\end{array}$ & 1 year \\
\hline \multicolumn{4}{|l|}{ FH/RL review of the above } \\
\hline \multicolumn{4}{|l|}{ Resolve comments } \\
\hline \multicolumn{4}{|l|}{ Assemble Class-3 modification package } \\
\hline \multicolumn{4}{|l|}{ FH/RL final review and approval process } \\
\hline Ecology Review Cycle & & $\begin{array}{l}\text { 1.0 FTE } \\
(\sim 2800 \text { hours })\end{array}$ & 1.5 years \\
\hline \multicolumn{4}{|l|}{$\begin{array}{l}\text { Submit to Ecology } \\
\text { Ecology review } \\
\text { NOD cycle } \\
\text { Workshops to resolve issues } \\
\text { Revise document } \\
\text { Certify } \\
\text { Printing/copying }\end{array}$} \\
\hline $\begin{array}{l}\text { Submit final modification package to Ecology for public } \\
\text { review }\end{array}$ & & $\begin{array}{l}0.5 \text { FTE } \\
(\sim 125 \text { hours })\end{array}$ & 5 days \\
\hline $\begin{array}{l}\text { Public Review (includes RL/FH comments on any new } \\
\text { Permit conditions) }\end{array}$ & & $\begin{array}{l}0.5 \text { FTE } \\
(\sim 85 \text { hours })\end{array}$ & 30 days \\
\hline $\begin{array}{l}\text { Ecology Response } \\
\text { Permit Preparation (FH activity) } \\
\end{array}$ & & $\begin{array}{l}0.5 \text { FTE } \\
(\sim 85 \text { hours })\end{array}$ & 30 days \\
\hline Permit Modification Finalized & & & 2 months \\
\hline
\end{tabular}




\subsubsection{Alternatives For Satisfying Applicable RCRA Requirements}

It is recommended to pursue full RCRA compliance. This would entail preparing and submitting a modification to the Part B permit for the MWDU.

Nevertheless a delisting petition could be pursued to allow disposal in a Subtitle ' $D$ ' or AEA (non-hazardous, radioactive) landfill. The administrative process to petition the EPA to amend 40 CFR Part 261 to exclude a waste (that is, delisting) is contained in 40 CFR 260.20 and 40 CFR 260.22. The administrative process includes: a petition by DOE of EPA to modify or amend 40 CFR 261; EPA evaluation of the petition; EPA publication of its tentative decision in the Federal Register, and issuance of a request for public comment; EPA evaluation of the public comments; and EPA arrival at a final decision. WPA publishes its final decision in the Federal Register and, if the petition is approved, will issue a regulatory amendment. Successful petitions to amend 40 CFR 261 can be found in 40 CFR 261, Appendix IX, and table 1.

The delisting approach would similarly streamline long-range operations but require much greater up-front document preparation and permit submittals. It is considered unlikely that a delisting petition would be granted for the grouted melters.

\subsubsection{Significant RCRA Issues}

The following represent issues that may affect the RCRA permitting of the disposal trench:

- Uncertainties in compiling material for modifying the Part B permit. A final approval for the permit is anticipated in the December 2002 time frame. Preparations to modify the Part B permit would need to begin in FY 2001 in order to meet the standard schedule for submittal of a class 3 modification to the HF RCRA permit. Preparation of the Class 3 modification to HF RCRA permit would require an estimated 3 years; this includes interim approvals by Ecology, prior to submittal of the final package. Formal review of the full package and public comment could add another 2 years.

- Reissuance of the HF RCRA Permit. The current HF RCRA permit expires in September 2004. The effort involved in re-issuing the HF RCRA permit may affect priorities for all RCRA related issues at Hanford. There may be significant delays in processing the modification to the permit or in reviewing and/or completing associated documents.

- Timing of rulings, delisting efforts, rulemaking changes, etc. Ecology only receives Part B modification request packages at specific times of the year, generally during the spring. All collection tasks to incorporate this target would be driven by this schedule. If not met, it could mean up to a year's delay in obtaining construction approval.

- Unknowns involving certification of the melter units (eg, chemical, biological, and physical analyses of the waste product) to be disposed of at the facility. While these are the final responsibility of the Vitrification Plant Contractor(VPC), delays in the final design process of the melter processing could add considerable delay to the transport and emplacement actions. 
- Acceptance of leachate at the 200 Area ETF. The leachate may potentially designate as F039. Waste acceptance criteria at 200 Area EFT needs to be addressed. In addition, permitting of the pipeline that will transport leachate from the MWDU disposal trench to the 200 Area ETF needs to be evaluated.

\subsubsection{Recommended Approach for Complying With RCRA}

It is recommended to prepare permit application documents as if the MWDU Part B is accepted. and approved by Ecology, by December 2002 (on schedule). Collection of design specifications and other information which will drive the final data set required to submit the pieces of the Class 3 modification should begin as soon as practical.

After Ecology's comments on all of the individual parts of the Class 3 modification package have been resolved, incorporated, and the text has been revised through a series of workshops, DOE would certify the modification to the Part B before formal submittal to Ecology. Ecology then processes the permit application.

\subsection{MELTER DISPOSAL TRENCH OTHER ENVIRONMENTAL DOCUMENTATION}

This section discusses steps required to complete NEPA/SEPA compliance, including Cultural and Ecological Resources Review; Air Permitting (e.g. Air Operating Permit); Excavation Permitting; Water and Waste Management, and Radioactive Waste Management.

Details on alternatives and issues in each area follow. Additional detail can be found in the environmental requirements checklist contained in Appendix F.

Many of the actions associated with the construction and operation of the disposal trench have been anticipated and are addressed in existing NEPA documentation.

Critical scheduling concerns include completion of NEPA/SEPA documentation before the start of definitive design of the trench.

Under the baseline assumption only minor modifications to the Air Operating Permit are expected. No issues have been identified for the excavation permit and water and waste management. The MWDU will develop or revise a radioactive waste management plan to address the melters.

A facility Performance Assessment (PA) is required for the Melter Disposal Trench as part of the MWDU. FH will revise the existing PA, as well as provide source term details to PNNL for the development of a Composite Analysis.

An assumption important in the evaluation of these issues is that the grouted melters are a sealed source. If this assumption is reversed, then addition analyses of this issues would be pursued. 
The Hanford Site Solid Waste Acceptance Criteria (HSSWAC) will need to be reviewed to ensure that melter disposal is addressed. The HSSWAC is revised as an.on-going site action.

The project must ensure that the revision in place at the time of melter disposal, and properly addresses acceptance of the melters.

\subsubsection{Federal and State Environmental Policy Acts}

The federal National Environmental Policy Act (NEPA) of 1969 was enacted to ensure that potential environmental, social, and other impacts are evaluated, and appropriate mitigation measures considered, before federal actions are initiated that might affect the quality of the human environment. The Washington State Environmental Policy Act (SEPA) is similar in effect to NEPA, and requires evaluation of environmental impacts associated with a project or an agency action before approval of the project or action is granted. In addition to these overarching environmental policy programs, there are several other environmental planning and assessment requirements that will impact the melter disposal process.

STRATEGY The recommended approach for complying with NEPA and SEPA requirements is to rely on existing NEPA records and documentation. The records and documentation should be reviewed to ensure the adequacy of coverage by the existing NEPA documentation and may be supplemented by a specific item-by-item evaluation when the final design details are completed. Table 2 shows the necessary activities, along with cost and schedule estimates, to achieve NEPA/SEPA compliance.

Table 2. Cost and Schedule Estimates for NEPA/SEPA Compliance.

\begin{tabular}{|l|l|c|}
\hline \multicolumn{1}{|c|}{ Activity } & \multicolumn{1}{|c|}{ Resource } & Duration \\
\hline NEPA/SEPA Compliance & & $3-4 \mathrm{mos}$ \\
\hline Review of existing NEPA documentation (EISs, etc). & Exempt $-80 \mathrm{hrs}$ & $1 \mathrm{mo}$ \\
\hline Identification of non-coverage issues \& project consultation & Exempt $-40 \mathrm{hrs}$ & $0.5 \mathrm{mo}$ \\
\hline Prepare NEPA recommendation letter for RL NEPA Office & Exempt $-40 \mathrm{hrs}$ & $0.3 \mathrm{mo}$ \\
\hline Consult with RL NEPA Office, RL Review \& issue decision & Exempt $-20 \mathrm{hrs}$ & $0.5 \mathrm{mo}$ \\
\hline Document NEPA compliance and boundary exceptions, if any & Exempt $-20 \mathrm{hrs}$ & $0.3 \mathrm{mo}$ \\
\hline Non-Exempt/Clerical at 30\% of Exempt time & Non-Exempt $-54 \mathrm{hrs}$ & \\
\hline Total NEPA & & $3 \mathrm{mos}$ \\
\hline $\begin{array}{l}\text { Prepare (ghost) letter to State requesting acceptance of existing NEPA } \\
\text { documentation in lieu of additional SEPA analysis. }\end{array}$ & Exempt $-20 \mathrm{hrs}$ & $0.2 \mathrm{mo}$ \\
\hline Consult with RL NEPA Office (concurrently with NEPA, above) & Exempt $-20 \mathrm{hrs}$ & $0.2 \mathrm{mo}$ \\
\hline Wait State SEPA approval & & $1-2 \mathrm{mos}$ \\
\hline Total SEPA (concurrent with NEPA effort) & & $2-3 \mathrm{mos}$ \\
\hline
\end{tabular}

With these two approvals granted, the project is allowed to go forward with preliminary design, etc.

5.3.1.1 NEPA/SEPA Requirements. The DOE NEPA requires that environmental considerations be identified and evaluated early in the planning process for all proposed department actions. All Hanford Site actions must have NEPA determinations before actions commence, and NEPA documentation must be completed before starting Title II Design or long 
lead procurements. DOE implements the NEPA compliance review by preparing an Environmental Impact Statement (EIS) or an Environmental Assessment (EA), or by issuing a Categorical Exclusion (CX) if the proposed action clearly has no significant impact on the quality of the human environment. DOE must approve, through the NEPA Compliance Officer, the NEPA reviews on the Hanford Site.

Many of the actions associated with the construction and operations of the vitrification plant and disposal trench have been anticipated and addressed in existing NEPA documentation, including the following:

- Tank Waste Remediation System, Hanford Site, Richland, Washington, Final Environmental Impact Statement (DOE 1996)

- "Record of Decision for the Tank Waste Remediation System" (62 FR 8693)

- Supplement Analysis for the Tank Waste Remediation System (DOE 1998a)

- Hanford Site Tank Waste Remediation System Programmatic Environmental Review Report (DOE 1998b).

- Hanford Solid Waste Environmental Impact Statement (DOE 1999, Draft) and Technical Data Package (HNF-4755, Draft C).

- Hanford Site Comprehensive Land Use Plan - Environmental Impact Statement (DOE 1999b).

The SEPA standards require evaluation of a project's environmental impacts before it can receive state or local permits or approvals. A SEPA checklist is completed to identify potential impacts and the lead agency (usually the initial permitting authority) decides whether an EIS is required or if a determination of non-significance can be issued. An EIS or EA developed under NEPA may substitute (at the option of the lead agency) for the SEPA checklist, and the lead agency can defer to the existing NEPA documentation in lieu of independent SEPA documentation. Past experience has been that Ecology is usually the lead agency for SEPA decisions at the Hanford Site, and that in most cases Ecology has been comfortable in accepting existing NEPA documentation as sufficient under SEPA.

\subsubsection{Alternatives for Satisfying Applicable NEPA and SEPA Requirements.}

a. Alternatives considered for ensuring NEPA compliance include the following:

- Prepare a new EIS or Supplemental Analysis (SA) to the existing environmental impact statements. The SA would be needed if a proposed action will have significant impacts to the human environment that have not been adequately bounded in previous EIS information. It is the opinion of FH Environmental Services that this is unnecessary. 
- Prepare an Environmental Assessment(EA) for the specific baseline option. An EA analyzes the environmental consequences of a proposed action and the alternatives to that action, and is prepared when there is uncertainty about the need for an EIS. The EA is a precursor to deciding whether an EIS, finding of no significant impact or further study is necessary. An EA might be necessary, if the baseline option proves unworkable during the final design of the vitrification processing and melter disposal trench.

- Issue a Categorical Exclusion (CX). If a proposed action falls within a category of actions not normally requiring an EA or an EIS, the action may be eligible for a CX. Sitewide CXs are applied to various types of activities specific to the Hanford Site. Specific-action CXs may be suitable under some of the secondary options for transport/disposal. The FH Environmental Services team concluded that the nature of the potential impacts (for the melter disposals as a whole) are not sufficiently considered under the $\mathrm{CX}$.

- Rely on existing NEPA documentation. The available body of EIS(s), EA(s), ROD(s), and other NEPA documentation may be relied on if it adequately bounds the range of impacts associated with a proposed action.

This is the proposed current strategy, while the two projects (vitrification processing and melter disposal) are still undergoing design.

b. Alternatives to be considered for SEPA compliance include the following:

- Prepare a SEPA checklist and an EIS. A SEPA checklist and EIS may be warranted if the lead agency determines the environmental impacts of a proposed action require further evaluation and mitigation.

- Prepare a SEPA checklist and obtain a determination of non-significance. If a proposed action would have minimal environmental impacts, a SEPA checklist could be submitted with enough information to allow the lead agency to issue a determination of non-significance.

- Rely on existing NEPA documentation. Reliance on NEPA documentation would be warranted as long as the NEPA process considered the range of environmental impacts and mitigation measures for a proposed project to at least the same extent as required by the SEPA standards. Because Ecology was a co-lead preparation agency on the TWRS EIS, it is not necessary for Ecology to adopt their own documentation.

This is the proposed strategy for SEPA under the baseline option.

\subsubsection{Significant NEPA/SEPA Issues.}

It is recommended that $F H$ and the $C H G$ vitrification design team conduct a joint review of existing NEPA for bounding coverage. The proposed strategy will optimize both time and resources during the final design of Phase 1 . 


\subsubsection{Recommended Approaches for Complying With NEPA and SEPA.}

The LLMW Melter Disposal Facility is a near-surface RCRA disposal unit.

The current NEPA documentation provides for management activities and addresses retrievable disposal of waste in RCRA-permitted landfill units. This facility is consistent with the RCRA subpart $\mathrm{C}$ activities analyzed in the EIS and the SA. Because the range of impacts associated with the disposal trench appear to be covered, in general the recommended approach is to rely primarily on the existing NEPA record.

Existing NEPA documentation will be reviewed after the design strategy and options are sufficiently defined, and a letter of concurrence from the RL NEPA Compliance Officer will be sought to confirm this expectation.. The adequacy of coverage by the existing NEPA documentation will, if necessary, be supplemented by a specific item-by-item evaluation when the final design details are complete. All final decisions for actions to satisfy NEPA will require direction and approval by the Waste Management Project.

\subsubsection{Cultural Resources And Ecological Compliance Reviews}

A Cultural Resources Review (CRR) is needed for any project involving excavation, demolition, modification, or deactivation near or at a facility or structure with potential historic, archaeological, or other cultural significance. This may include any artifacts that have importance for Native American preservation, materials that have interpretive or educational value as exhibits within local, state, or national museums, or any facility with the potential for inclusion on the National Register of Historic Places.

An Ecological Compliance Review (ECR) is needed if planned activities could disturb plant or animal species or their habitats. The objective of the review is to determine the occurrence of any plant and animal species protected under the Endangered Species Act (ESA), candidates for such protection, and species listed as threatened, endangered, candidate, sensitive, or monitor by the state of Washington, and species protected under the Migratory Bird Treaty Act. The review also is conducted to evaluate and quantify the potential impacts of disturbance on priority habitats and protected plant and animal species identified in the survey. This includes species that are or may be threatened, endangered, candidate, sensitive, or are otherwise protected under state and federal laws and regulations. This also includes taking, possession, transportation, sale, purchase/barter, export, or import of special status plants and animals (both living and dead).

No adverse impacts to species, habitats, or other biological resources are expected to result from the proposed actions. The adequacy of the current Cultural/Ecology Resources Requirements (CERR) will be evaluated periodically in coordination with the facility operations manager as other activities are planned. Supplemental information would be developed as necessary to update the initial review. Table 3 shows the necessary activities, along with cost and schedule estimates, to obtain appropriate cultural resource and ecological reviews. 
Table 3. Cost and Schedule Estimates for Cultural and Ecological Reviews.

\begin{tabular}{|l|l|l|}
\hline \multicolumn{1}{|c|}{ Activity } & Resource & Duration \\
\hline Cultural and Ecological Resources Review & & \\
\hline $\begin{array}{l}\text { Consult with and initiate request to PNNL, to update their annual effort } \\
\text { and include MWDU specifically in letter report }\end{array}$ & Exempt $-10 \mathrm{hrs}$ & $0.5 \mathrm{mo}$ \\
\hline $\begin{array}{l}\text { Consult with WMNW and initiate request for ecological survey. Include } \\
\text { in letter report }\end{array}$ & Exempt $-20 \mathrm{hrs}$ & $0.5 \mathrm{mo}$ \\
\hline $\begin{array}{l}\text { CERR letter reports may be not issued until 6 months after request, but the prior reviews would hold true, unless } \\
\text { verbally notified by performing organization to the contrary. The CERR report is filed with general project } \\
\text { planning documents for NEPA. }\end{array}$ & Exempt $-20 \mathrm{hrs}$ & $\begin{array}{l}0.5 \mathrm{mo} \\
\text { Monitoring } \\
\text { takes } 1-2 \text { years }\end{array}$ \\
\hline $\begin{array}{l}\text { Environmental Baseline Monitoring } \\
\text { Consult with WMNW, provide charge authorization for monitoring }\end{array}$ & & Exempt -40 \\
\hline hrs & 0.5 mo \\
\hline Peview monitoring results, provide letter to file of acceptability & $\begin{array}{l}\text { Exempt }-100 \\
\text { hrs }\end{array}$ & 1 mo \\
\hline Baseline monitoring provides input for facility design \& PA & & \\
\hline
\end{tabular}

\subsubsection{Alternatives for Satisfying Applicable Cultural/Ecological Requirements.} Alternatives to be considered for assuring CRR and ECR compliance include the following:

- Show that existing CERR documentation suitably covers the proposed action and has no significant cultural/ecological impacts

- Perform independent reviews for a proposed action.

5.3.2.2 Significant Cultural/Ecological Issues. A CERR review has been requested through the proper channels for the construction of the vitrification facility, and the existing survey inside the 200-East Area bounds operation of the melter trench in the 218-E-12B LLBG. Any new results of that review will be made available to the project management.

\subsubsection{Recommended Approaches for Complying with Cultural/Ecological Requirements.} A request will be made to Pacific Northwest Laboratory (PNNL) for a detailed review within the west end of the 218-E-12B LLBG. This survey will be phased in with the normal CERR activities associated with the 200-East Area In the existing survey, the following were noted:

- No plant or animal species protected under the federal ESA, candidates for such protection, or species listed by the Washington state government as threatened or endangered have been observed in the vicinity of the proposed site.

- Depending on the final project design, it is anticipated that the proposed project will result in the loss of between 25 and 33 ha ( 62 to $82 \mathrm{ac}$.). This level of impact will require compensatory mitigation via habitat replacement as described within the Hanford Site Biological Resources Management Plan (DOE 1996). It is recommended that project planners contact the PNNL Ecological compliance staff during the early project preparation phases to develop an appropriate Mitigation Action plan. 
- The proposed project area is used for nesting by numerous migratory birds. Therefore, no vegetation removal or disturbance should occur during the nesting and fledging seasons; i.e., between 1 April and 31 July.

- No adverse impacts to species, habitats, or other biological resources are expected to result from the proposed actions.

- The adequacy of the current CERR will be evaluated periodically in coordination with the facility operations manager as other activities are planned. Supplemental information would be developed as necessary to update the initial review.

\subsubsection{Environmental Monitoring of Facilities, Sites, and Operations}

An evaluation of baseline environmental conditions (preoperational monitoring) must be conducted before startup of a site, facility, or process that has the potential for significant adverse environmental impact or for emissions of hazardous materials or radioactive substances. The basic monitoring required includes radionuclide concentrations in the ambient air, background radiation levels at the project site and in surrounding areas, and radionuclides present in flora, fauna, soil, wildlife, and water. Baseline levels of hazardous chemicals present in the environment may also be of interest. Preoperational monitoring should begin not less than one year (preferably 2 years) before startup, so seasonal changes can be evaluated. This information can be used for comparative purposes during periodic, near-facility monitoring to determine if facility operations and emissions are affecting the environment.

The monitoring plan shall be implemented within one year of the issuance of this disposal authorization. This plan shall be updated at least every five years to reflect the changing facility conditions. The plan shall include monitoring frequencies and protocols for all the data collection required to assess the continued performance of the disposal facilities. These plans shall also include a requirement for comparison with the performance assessment results and development of any corrective action necessary."

A large amount of information is available regarding environmental conditions and operational monitoring in and near the LLBG site for the melter disposal trench. This information is relevant to the facility, and is provided in various documents, including but not limited to:

- Environmental Monitoring Plan - United States Department of Energy, Richland Operations Office (DOE 1997b)

- Facility Effluent Monitoring Plan for the Facilities (Crummel et al. 1999)

- Environmental Releases for Calendar Year 1997 (Gleckler 1998) 
- Hanford Site Near-Facility Environmental Monitoring Annual Report, Calendar Year 1997 (Perkins et al. 1998)

- Hanford Site Environmental Report for Calendar Year 1998 (Dirkes et al. 1999).

During the final design of the disposal trench and the melter process for compliance to LDR (identified as an interface between WMP/VPC), detailed effort will develop an environmental monitoring plan for the LLBG, which incorporates estimated potential for emissions from the melters to be disposed. Work in fiscal Year 2001 will lay the basis for satisfying the DOE Order 435.1 requirements as well as establish the environmental monitoring baseline for the facility.

\subsubsection{Alternatives for Satisfying Environmental Monitoring Requirements.}

There are no other alternatives that warrant consideration at this time.

\subsubsection{Significant Environmental Monitoring Issues.}

The final status of the grouted melter units, must have concurrence from Ecology and DOH on the potential to emit contamination.

\subsubsection{Recommended Approach for Environmental Monitoring.}

Environmental compliance requirements could be met by using the existing Near-facility environmental monitoring program, executed by WMNW. A detailed evaluation must take place for any changes in the potential to emit, in the melter source term(s), as well as in any decision to emplace other mixed waste, other then grouted melters, into the trench.

\subsubsection{Mitigation Action Plan}

Through the NEPA process, DOE intends to implement reasonable measures to minimize the impacts to the environment. A Mitigation Action Plan (MAP) will have to be prepared in compliance with the Council on Environmental Quality Implementing Regulations [40 Code of federal Regulations (CFR) 1500-1508] for NEPA and DOE NEPA regulations (10 CFR 1021).

The Washington Department of Fish and Wildlife (WDFW) considers the primary impact from the construction of the disposal trench to be the removal of the shrub-steppe habitat. This habitat is dominated by big mature sagebrush and is recognized as a Priority Habitat by WDFW.

These requirements should addressed during final trench design.

5.3.4.1 Alternatives for Satisfying Mitigation. Alternatives to be considered during the trench design are as follows:

- Amending the current MAP for vitrification Phase 1

- Developing a stand-alone LLBG Facility MAP. 
5.3.4.2 Significant Mitigation Issues. No significant issues have been identified that require resolution at this time.

5.3.4.3 Recommended Approach for Mitigation Compliance. The proposed disposal trench site is located inside an existing designated LLBG. The area may be undisturbed land, however, it has no other feasible uses. A MAP could be developed that establishes plans and procedures by which the facility representatives can mitigate the impacts to this site, in coordination with the long-range land use EIS. Full implementation of the Comprehensive Land-Use EIS [DOE/EIS0222F, (Sept 1999)] will not occur until after closure of the LLBG, at which time, at least part of the land will be allowed to return to the shrub-steppe conditions that are now seen.

There is no defined, prescriptive formula or specific requirements to mitigate or rectify the loss of shrub-steppe habitat that will be destroyed with the construction of the trench. However, a modification of the existing MAP would be made following the trench design. DOE has regular comment periods for the public to provide input on mitigation and other environmental supportive issues

\subsubsection{Excavation Permit}

An Excavation Permit is required before initiating any potential surface-disturbing onsite activities. The review and approval process will consider proposed locations for all underground piping, pits, pads, and support structures, and should evaluate for possible intrusion into radiation control areas, underground contamination areas and buried tanks to avoid unanticipated exposures. The excavation permit also provides a final checkpoint for the Environmental Compliance Officer (ECO) to ensure that the required cultural, ecological, preoperational monitoring, permitting, and other environmental compliance actions have been adequately completed.

The depth to groundwater in the 200-East Area is approximately 200 feet $(60 \mathrm{~m})$; therefore, there should be no impact on groundwater from construction or emplacement actions in the trench. Detailed information needed for excavation permits will be provided during final design. The Excavation Permit must be approved by the LLBG ECO.

Table 4 shows the necessary activities, along with cost and schedule estimates, to obtain appropriate excavation permit.

Table 4. Cost and Schedule Estimates for Excavation Permit.

\begin{tabular}{|l|l|l|}
\hline \multicolumn{1}{|c|}{ Activity } & Resource & Duration \\
\hline Excavation Permit & & \\
\hline $\begin{array}{l}\text { Consult with Vitrification facility design, MWDU Environmental } \\
\text { Compliance Officer, and Regulatory staff }\end{array}$ & Exempt - 150 hrs & 2 mos \\
\hline $\begin{array}{l}\text { Permit is actually requested by Construction forces, after final design } \\
\text { is approved. }\end{array}$ & & \\
\hline
\end{tabular}

5.3.6.1 Alternatives for Satisfying Excavation Permits. There are no alternatives to be considered for the excavation permit requirement. 
5.3.6.2 Significant Excavation Permit Issues. No significant issues have been identified that require resolution at this time.

5.3.6.3 Recommended Approach for Excavation Permit Compliance. The LLBG facility management will develop the necessary information required to obtain the Excavation Permit.

The LLBG ECO will identify any significant cultural resource or ecological compliance issues before issuing Excavation Permits.

Other environmental compliance issues should be resolved before disposal is begun.

\subsubsection{DOE Acquisition/Environment, Safety and Health Management}

As a condition of DOE acquisition regulations (DEAR clauses), the VPC and WMP contractors must ensure that actions are integrated through the sitewide Integrated Environment, Safety and Health Management System (ISMS). Each project and activity that supports the melter disposals must ensure that ISMS is implemented in their work. The ECO will ensure that applicable environmental requirements are identified and implemented for the Melter Disposal trench, consistent with the requirements and objectives of the ISMS.

A Quality Assurance Plan (QAP) for construction of the trench, pipeline, and transporter modifications will be developed. This QAP plan will also control tier-down of other requirements to sub-contractors, as applicable.

5.3.7.1 Alternatives for Satisfying ISMS. There are no alternatives that warrant consideration for this requirement.

5.3.7.2 Significant ISMS Issues. No significant issues have been identified that require resolution at this time.

5.3.7.3 Recommended Approach for Implementation of ISMS. The ECO will ensure that ISMS is integrated and implemented from the inception of the design work throughout the operation of the facility. The appropriate requirements must be identified for a successful ISMS implementation.

\subsubsection{Air Permitting}

The purposes of the federal Clean Air Act (CAA) and the Washington State Clean Air Act (WCAA) are to protect public health and welfare by safeguarding air quality, bringing polluted air into compliance, and protecting clean air from degradation. The CAA and WCAA provide the authority for monitoring and controlling emissions of radioactive and nonradioactive constituents to the air. In Washington State, the U. S. Environmental Protection Agency (EPA), Ecology, Washington State Department of Health (DOH), and Benton (county) Clean Air Authorities oversee compliance to air quality standards. 
The DOH regulates radioactive air emissions in Washington State. All emissions of radionuclides are regulated under WAC 246-247. Nonradioactive air emissions are regulated by Ecology. Any new activity (including any new construction work), process, or equipment that will involve potential emissions of pollutants or radionuclides to the air is subject to a preconstruction review and approval, which is initiated by submittal of the Notice of Construction (NOC) to Ecology or DOH.

State regulations (WAC 173-401) establish a comprehensive Washington State Air Operating Permit (AOP) program that meets federal requirements and has been approved by EPA. The purpose of the AOP is to consolidate into a single document all of the air regulations applicable to a source, in order to facilitate source compliance and enforcement. A single sitewide permit, the Hanford AOP, is required for the Hanford Site and will cover all radioactive and nonradioactive airborne emissions.

The Hanford AOP is nearing final approval, and procedures for maintaining and updating the Hanford AOP are under development. Signatories to the Hanford AOP will include Ecology, $\mathrm{DOH}$, and BCAA.

Under the baseline assumption that melters will be encased in an overpack and completely grouted at the VPC, the recommended approach will be to request exemptions from applicable air permitting requirements based on the lack of potential to emit either radioactive or nonradioactive constituents.

\subsubsection{Alternatives for Satisfying Applicable Permitting Requirements.}

5.8.3.1.1 Alternatives for Radioactive Air Emissions. The preferred alternative is for LLBG facility to seek a "sealed source exemption" for the grouted melters. According to WAC 246-247-020, a source meeting the definition of sealed source is exempt from the requirements of this chapter, "because they release no airborne radioactivity, or they prima facie comply with the standards in WAC 246-247-040, or they are already adequately regulated under other requirements."

As defined within WAC 246-247-030, a sealed source means, "radioactive material that is permanently bonded or fixed in a capsule or matrix, or radioactive material in airtight containers, designed to prevent release and dispersal of the radioactive material under the most severe conditions encountered in normal use and handling." The grouted melter package will be sealed in overpack containers that are leak tight, as defined in American National Standards Institute (ANSI) N14.5. Each container will be decontaminated and surveyed, to meet the requirements specified in 49 CFR 173.443(a), before being transferred from the private vendor.

Should the requested exemptions be denied by $\mathrm{DOH}$, an NOC requesting approval to modify the LLBG would be required to be submitted to DOH under WAC 246-247-060.

Table 5 shows the necessary activities, along with cost and schedule estimates, to comply with radio active air emissions requirements. 
Table 5. Cost and Schedule Estimates for Radioactive Air Emission Permits.

\begin{tabular}{|l|l|c|}
\hline \multicolumn{1}{|c|}{ Activity } & Resource & Duration \\
\hline Radioactive Air permits & & \\
\hline Present issues in technical interface meeting & Exempt -40 hrs & $1 \mathrm{mo}$ \\
\hline $\begin{array}{l}\text { Prepare Notice Of Construction, after baseline option has state DOH } \\
\text { concurrence }\end{array}$ & Exempt -150 hrs & $2 \mathrm{mos}$ \\
\hline Prepare input data for Part B & Exempt -100 hrs & $1 \mathrm{mo}$ \\
\hline Non-Exempt clerical support @ 30\% Exempt time & $\begin{array}{l}\text { Non-Exempt - 45 } \\
\text { hrs }\end{array}$ & \\
\hline Obtain onsite approvals, submit to Wash DOH & Exempt - 80 hrs & 1 mo \\
\hline Wait DOH approval & & $1-2$ mos \\
\hline DOH approval is needed prior to compilation of full RCRA Part B Permit modification package. \\
\hline
\end{tabular}

Radioactive and nonradioactive NOCs can be prepared concurrently, using much of the same information. Usual duration 4-5 months.

5.3.8.1.2 Alternatives for Nonradioactive Air Emissions. Provided the baseline option is followed, constructing and operating the melter disposal trench as part of the 218-E-12B LLBG is not expected to modify existing sources of air emissions, nor add new sources that do not currently exist, therefore, this project is not subject to the NSR or preconstruction approval requirements. Verification that the packages that will arrive at the LLBG are leak tight should eliminate the potential to emit and therefore eliminate applicable requirements.

Should an alternate option be chosen, or the grouted melter units cannot be verified as airtight, a NSR and NOC could potentially be required to be submitted to Ecology.

Table 6 shows the necessary activities, along with cost and schedule estimates, to comply with nonradioactive air emissions requirements.

Table 6. Cost and Schedule Estimates for Nonradioactive Air Emission Permits.

\begin{tabular}{|l|l|l|}
\hline \multicolumn{1}{|c|}{ Activity } & Resource & Duration \\
\hline NonRadioactive Air Permits & & \\
\hline $\begin{array}{l}\text { Similar as the radioactive components, above. The interface is with } \\
\text { Ecology, the submittal letter format is slightly different, but the } \\
\text { information is very much alike. The outcome is similar. }\end{array}$ & & \\
\hline Present issues in technical interface meeting, & & \\
\hline $\begin{array}{l}\text { Prepare Notice of Construction, after baseline option has state Ecology } \\
\text { concurrence }\end{array}$ & Exempt - 250 hours & 4 mos \\
\hline Non-Exempt/Clerical support & $\begin{array}{l}\text { Non-Exempt - } \\
85 \text { hours }\end{array}$ & \\
\hline
\end{tabular}

Radioactive and nonradioactive NOCs can be prepared concurrently, using much of the same information. Usual duration 4-5 months.

5.3.8.1.3 Alternatives for Hanford Site Air Operating Permit (AOP). The preferred alternative under the baseline option is for the melters to be exempted from $\mathrm{DOH}$ regulation and 
should not be subject to Ecology regulation. Should the exemption be approved by DOH, no AOP modifications will be required.

Should the exemption not be approved by Ecology, or Ecology finds the melters to have a potential to emit -- the AOP would be modified to include the open melter disposal trench as part of the LLBG emissions.

Table 7. shows the necessary activities, along with cost and schedule estimates, to comply with Hanford Air Operating Permit requirements.

Table 7. Cost and Schedule Estimates for Air Operating Permit Modification.

\begin{tabular}{|l|l|l|}
\hline \multicolumn{1}{|c|}{ Activity } & Resource & Duration \\
\hline Hanford Air Operating Permit Modification & & \\
\hline Review existing site data, identify possible changes needed & Exempt $-80 \mathrm{hrs}$ & $1 \mathrm{mo}$ \\
\hline $\begin{array}{l}\text { Interface with design team, NEPA specialists, MWDU unit staff to identify } \\
\text { required information }\end{array}$ & Exempt $-160 \mathrm{hrs}$ & $2 \mathrm{mos}$ \\
\hline Revise needed document package & Exempt $-160 \mathrm{hrs}$ & $1.5 \mathrm{mos}$ \\
\hline Consult with RL/State regulatory review & Exempt $-40 \mathrm{hrs}$ & $2-3 \mathrm{mos}$ \\
\hline Revise and resubmit after State review/comment & Exempt $-80 \mathrm{hrs}$ & $1.5 \mathrm{mos}$ \\
\hline Non-exempt/clerical assistance at 30\% of Exempt time & $\begin{array}{l}\text { Non-Exempt }- \\
140 \mathrm{hrs}\end{array}$ & \\
\hline Minimum estimated time (baseline option) for AOP revision due to melters & & $\sim 8 \mathrm{mos}$ \\
\hline
\end{tabular}

5.3.8.2 Significant Air Permitting Issues. Under existing regulations, a source is considered "significant" if it has the potential to contribute more than one percent (>1\%) of the overall Hanford Site exposure to the general population. Designation of the grouted melter unit(s) as a "strong, tight source," with no potential to emit is a critical issue for the baseline assumption. Under the baseline option, the melters would not be designated as significant sources.

Concurrence from DOH on the status of the melters as sealed sources remains the highest environmental priority. The status of the grouted melters as "sealed sources" is required in order to proceed to final design under the baseline option.

The baseline option environmental impacts are minimal; however, there are secondary options; e.g., transport of overpack and melter to trench prior to grouting, being considered, which would require extensive analysis and permit applications.

There are no separate significant issues under the baseline option.

Note: Fugitive dust, particulates, and even ash dispersed by local winds are considered outside the scope of the AOP control for melter disposal. Dust suppression will be controlled under the construction quality assurance plan.

5.3.8.3 Recommended Approach for Complying with Air Permitting Requirements. The recommended approach for radioactive air emission permitting issues is to request a sealed 
source exemption from DOH by submitting a letter, coupled with current design information available from the design team. This could be presented in the routine technical assistance meeting (RTAM) facilitated by WMP Environmental Services. This approach is similar to that used by the Immobilized LAW Disposal Project( W-465, W-520 AND W-025).

The recommended approach for nonradioactive air emission permitting issues, provided that the baseline option is followed, is for project representatives to coordinate with the facility ECO during initial planning stages to determine the containers are indeed airtight and have no potential to emit. It is recommended that the documented findings be presented to Ecology and request concurrence that no approval will be required for the scope of work. The result will be documented indicating that an NSR and approval are not required.

5.3.8.4 Interfaces Issues. While the designation of the melters are sealed sources under the baseline option for disposal is not considered a significant issue , the solid waste stream exiting the Vitrification Facility must be included in the NOC submitted by the Facility to the State. Since this is the responsibility of the vitrification Contractor, it is considered outside the scope of the melter dsposal and this permitting strategy.

"Define the interface between the vitrification operation and acceptance of the melters " must be negotiated during the final design stage of both the vitrification facility and the design of the transporter, in order to ensure that required concurrences with the state regulators are well understood.

\subsubsection{Water And Waste Water Management}

Only minor impacts are assumed between the melter disposal trench and the 200-East Area water supply system. No permanent sanitary sewer will be involved with trench operations. If needed, portable outhouses can be moved into the LLBG for temporary use and serviced at regular intervals. Potable water will be supplied in portable containers.

Table 9 shows the necessary activities, along with cost and schedule estimates, to comply with water and wastewater requirements.

Table 9. Cost and Schedule Estimates for Water and Wastewater Management.

\begin{tabular}{|l|l|c|}
\hline \multicolumn{1}{|c|}{ Activity } & Resource & Duration \\
\hline $\begin{array}{l}\text { Water and Waste Water Management } \\
\text { (Permits for rainwater, effluent handling) }\end{array}$ & & \\
\hline Review of existing permits, agreements and design criteria & Exempt $-100 \mathrm{hrs}$ & $1 \mathrm{mo}$ \\
\hline Preparation of permit(s) modifications, internal reviews & Exempt $-160 \mathrm{hrs}$ & $2.5 \mathrm{mos}$ \\
\hline Consultation with RL and regulatory staff, regulator reviews & Exempt $-80 \mathrm{hrs}$ & $1 \mathrm{mo}$ \\
\hline Non-Exempt clerical support, document preparation & Non-Exempt $-80 \mathrm{hrs}$ & \\
\hline Onsite review/approval, State approvals & Exempt $-40 \mathrm{hrs}$ & $1-2 \mathrm{mos}$ \\
\hline Note Groundwater monitoring requirements in section 1.0, above & & \\
\hline
\end{tabular}


The baseline option assumes that the melter disposal trench will be a RCRA-compliant landfill complete with a double liner and leachate control system. The facility also might need to dispose of wastewater from hydrotesting, cooling, condensation, and/or stormwater collection. Under the baseline assumption, this liquid will be directly transported to the 200 Area ETF, by a RCRA-compliant pipeline.

Since the melter units themselves are considered sealed sources under the baseline assumption, no impacts to the water quality protection requirements are expected.

5.3.9.1 Drinking Water Systems. Portable containers will be used for drinking water whenever personnel are assigned to be working in the disposal trench area of the 218-E-12B LLBG. Portable containers will also be used during the construction of the trench and placement of the liner and leachate system.

5.3.9.1.1 Alternatives for Satisfying Drinking Water System Standards. There are no other alternatives that warrant consideration at this time.

5.3.9.1.2 Significant Issues for Drinking Water Systems. There are no significant drinking water issues requiring resolution at this time.

5.3.9.1.3 Recommended Approach for Drinking Water Systems. The baseline assumption uses portable containers on an as-needed basis. Once the disposal trench is constructed and in permitted operation, an engineering study may be used to determine the need for permanent tie-in to the Hanford potable water supply system, ID $\# 41866 \mathrm{~V}$, under control of the Water Purveyor's office.

5.3.9.2 Domestic Waste Water Disposal. For Septic System Approvals/Permits $(<14,500$ GPD Design Capacity) [WAC 246-272, WDOH], no permanent sanitary sewer and disposal system are assumed under the baseline option. Portable outhouses could be used during construction, and whenever actual melter trench emplacement is required. The melter trench will be unoccupied by workers most of the time, except during routine inspections and surveillance tasks.

\subsection{Alternatives for Satisfying Domestic Waste Water Disposal Standards.} There are no other alternatives that warrant consideration at this time.

5.3.9.2.2 Significant Issues for Domestic Waste Water Disposal. A secondary option is possible to delist all wastewater and avoid the liner requirement for the trench as discussed in section 4.1. Any effort to delist would require extensive analysis and permit modifications; however, the naval reactor disposal trench, Trench 94, which is in the same 218-E-012B area, is operated in this manner.

\subsection{Recommended Approach for Domestic Waste Water Disposal. No} domestic wastewater will be generated under the melter disposal baseline option. Leachate and rainwater collected in the trench will be transferred to the 200 Area ETF, via a RCRA-compliant pipeline. 
5.3.9.3 State Waste Discharge Permit. A State Waste Discharge Permit (SWDP) is required for any industrial, commercial, or municipal operations that may discharge waste materials in a manner that could pollute the groundwater of the state.

Before construction or modification, facilities requiring disposal under SWDP permit must submit an application to Ecology, and must provide engineering reports, plans, and specifications for the project in accordance with WAC 173-216 and WAC 173-240. Ecology must approve the SWDP application and accompanying materials before construction begins. Operation and maintenance manuals must be submitted before construction is completed. A monitoring system and plan is usually required, which may include effluent testing, vadose zone measurements, and/or groundwater sampling and analysis.

Activities covered by an existing SWDP must comply with the conditions of the permit or the permitted facilities waste acceptance criteria (WAC). Effluent control systems typically include a combination of best management practices (BMPs) to minimize effluent and pollutant generation, and use of all known, available, and reasonable treatment for effluent streams prior to discharge.

Ecology has issued several SWDPs for the Hanford Site that may affect the melter disposal trench, within the 218-E-12B LLBG. The permits include SWDP ST 4500 for the 200 Area ETF and three categorical SWDPs that regulate miscellaneous stream discharges. Wastewater discharges to the ETF will be required to meet the facilities wastewater acceptance criteria. Each of these categorical SWDPs includes conditions on the rate and quantities of discharges, sources of water, BMPs that must be developed and implemented, and record keeping and reporting. These categorical permits include:

- SWDP ST 4508; Hydrotest, Maintenance, and Construction Locations on the Hanford Site. No impact to this permit except briefly during the construction phase of the trench. All rainwater will be assumed to be suitably disposed to the soil as non-contaminated during this period.

- SWDP ST 4509; Cooling Water and Condensate Discharge Locations on the Hanford Site. No impact to this permit from the melter disposal activities.

- SWDP ST 4510; Industrial Stormwater Discharges to Engineered Land Disposal. Structures on the Hanford Site. Liquid disposal by the ETF will be covered by this permit, but the melter trench will only need to comply with the acceptance criteria of the ETF, in order to transfer the leachate to the ETF during melter trench operations.

The conditions in the SWDPs are self-implementing. Affected LLBG melter disposal activities should not require prior agency approval as long as permit conditions are met.

5.3.9.3.1 Alternatives for Satisfying SWDP Requirements. A secondary option is possible to delist all wastewater and avoid the liner requirement for the trench as discussed in Section 4.1. Any effort to delist would require extensive analysis and permit modifications; 
however, the naval reactor disposal trench, Trench 94, which is in the same 218-E-012B area, is operated in this manner.

5.3.9.3.2 Significant SWDP Issues. No significant SWDP issues have been identified that require resolution at this time.

5.3.9.3.3 Recommended Approach for SWDP Strategies. The melter disposal trench will be a RCRA-compliant landfill under the baseline option. It will include a double liner and a leachate collection system. The leachate that is collected will be piped to the Liquid Effluent Retention Facility (LERF), for treatment in the 200 Area ETF. The melter trench leachate will have to meet the WAC of ETF. If subject to the ETF WAC, the melter disposal trench should plan on designing for a composite sampler, and a $\mathrm{pH}$ meter, and also for a constant readout flowmeter with a strip chart.

\subsubsection{Radioactive Materials And Waste Management}

DOE orders provide standards and guidelines for limiting public and environmental exposures to radionuclides, and require a written Environmental Monitoring Plan (EMP) for each site, facility, or process that uses, generates, releases, or manages significant pollutants or hazardous materials. The effluent monitoring portion of each EMP must verify compliance with applicable regulations and DOE Orders. An EMP has been prepared for all DOE activities on the Hanford Site and is updated every 3 years to include new or modified facilities and projects (DOE 1997b). Effluent monitoring is documented for each major facility on the Hanford Site through a specific Facility Effluent Monitoring Plan (FEMP).

As part of the compliance with DOE 435.1, a waste management plan for the Hanford site has been developed. This general plan will be implemented in facility operations and waste generation sitewide beginning in FY 2001

Table 10 shows the necessary activities, along with cost and schedule estimates, to comply with radiaoctive waste management requirements.

Table 10. Cost and Schedule Estimates for Radioactive Waste Management.

\begin{tabular}{|l|l|l|}
\hline \multicolumn{1}{|c|}{ Activity } & Resource & Duration \\
\hline Radioactive Waste Management & & \\
\hline $\begin{array}{l}\text { MWDU \& ES Review DOE Order 435.1 criteria, sitewide implementation } \\
\text { plan, and incorporate into MWDU facility management plan (MWDU Lead, } \\
\text { ES supporting). }\end{array}$ & Exempt $-150 \mathrm{hrs}$ & $4 \mathrm{mos}$ \\
\hline ES Provide input to MWDU operational procedures for melter acceptance & Exempt $-150 \mathrm{hrs}$ & $2 \mathrm{mos}$ \\
\hline Interface/add trench design specs into other site documents & Exempt $-100 \mathrm{hrs}$ & $3 \mathrm{mos}$ \\
\hline $\begin{array}{l}\text { Interface/add checklist requirements into the trench final design, review } \\
\text { design }\end{array}$ & Exempt $-150 \mathrm{hrs}$ & $6 \mathrm{mos}$ \\
\hline Provide ES input to PA revision by Systems Engineering & Exempt $-80 \mathrm{hrs}$ & $2 \mathrm{mos}$ \\
\hline Provide ES input to CA development by PNNL & Exempt $-40 \mathrm{hrs}$ & $1 \mathrm{mo}$ \\
\hline
\end{tabular}

The facility radioactive waste management plan must be approved prior to the readiness review. 
5.3.10.1 Alternatives for Radioactive Materials and Waste Management. There are no alternatives that warrant consideration at this time.

\subsubsection{Significant Issues for Radioactive Materials and Waste Management. No} significant issues have been identified that require resolution at this time.

5.3.10.3 Recommended Approach for Radioactive Materials and Waste Management. The requirements of DOE 435.1 will be reviewed and incorporated into the site waste management plan, and all subordinate implementing plans.

The LLBG will not require a FEMP due to the assumed sealed source characteristics of the melter units. The facility will not be a source of air emissions, and because the facility will transfer all leachate to the ETF a FEMP will not be required.

5.3.10.4 DOE Order 435.1 Compliance. The LLBG will develop a plan to manage the melters under its control, via a Radioactive Waste Management Plan. This will be tiered-down from the site implementation plan, DOE/RL-2000-25.

A Performance Assessment (PA) is required for the melter trench, as part of the 218-E-12B LLBG. FH Systems Engineering will revise the existing PA, as well as provide source term details to PNNL, for the development of a Composite Analysis (CA). These documents provide computer-generated estimates, based on a statistical approach for maximum radioactive-based dose/exposure to a theoretical individual as part of the general population.

Table 11 shows the necessary activities, along with cost and schedule estimates, to comply with performance assessment and composite analysis requirements.

Table 11. Cost and Schedule Estimates for Performance Assessment/Composite Analysis.

\begin{tabular}{|c|c|c|}
\hline Activity & Resource & Duration \\
\hline \multicolumn{3}{|l|}{ MWDU Performance Assessment/Site Composite Analysis } \\
\hline $\begin{array}{l}\text { Review final design, identify potential dose sources for modification of the } \\
\text { existing PA } \\
\text { - Safety/Systems Engineering } \\
\text { - Environmental Services }\end{array}$ & $\begin{array}{l}\text { Exempt }-4.0 \mathrm{FTE} \\
\text { Exempt }-200 \mathrm{hrs}\end{array}$ & 2 years \\
\hline \multicolumn{3}{|c|}{ Start after preliminary design complete, finish prior to final Part B modification approval } \\
\hline $\begin{array}{l}\text { Review final design, identify potential dose sources for site composite } \\
\text { analysis }\end{array}$ & Exempt $-100 \mathrm{hrs}$ & $1 \mathrm{mo}$ \\
\hline Provide funding to PNNL for MWDU inclusion in CA & $\begin{array}{l}\text { Managerial/Procu } \\
\text { rement }-20 \mathrm{hrs}\end{array}$ & $1 \mathrm{mo}$ \\
\hline $\begin{array}{l}\text { Provide applicable information from final design \& Part B to PNNL/ Review } \\
\text { CA }\end{array}$ & Exempt $-100 \mathrm{hrs}$ & $6 \mathrm{mos}$ \\
\hline $\begin{array}{l}\text { CA is part of final closure planning, but details not required until last melter } \\
\text { is in place }\end{array}$ & & $\sim 10$ years ${ }^{+}$ \\
\hline
\end{tabular}
ready for closure.

The PA \& CA revisions will be ongoing throughout the trench operations, needing final revision when 
There are no other options, and this becomes the preferred baseline strategy.

The LLBG must begin developing individual implementation from the site plan during FY 2001, but any revisions to the implementation would not need to be in place until the final readiness review has begun.

\subsubsection{Hazardous Substances}

Work associated with the development and operation of the melter disposal trench is not expected to handle or encounter a wide range of nonradioactive hazardous substances that are subject to federal and state regulations. In general, sitewide procedures already exist and are implemented as needed by projects and activities conducted on the Hanford Site. The hazardous substance programs that are potentially applicable to the disposal are summarized in this section.

5.3.11.1 TSCA Regulated PCBs. The current assumption is that the grouted melters will not be TSCA regulated for PCB concentration, however, this assumption needs further evaluation.

The tank farm waste is currently undergoing analyses for determination of TSCA applicability. It is currently proposed in negotiations with the regulators that the waste in the double shell tanks be declared PCB remediation waste. TSCA applicability for the vitrification plant and waste generated the vitrification plant (e.g. failed or excess melters) is also being negotiated and must be resolved.

If the grouted melters are determined to be or contain TSCA regulated $P C B$ waste (such as $P C B$ remediation waste) a regulatory analyses should be performed to determine if TSCA regulations allow the waste to be disposed in the trench or if additional TSCA approvals are required.

5.3.11.2 Ozone Depleting Substances. EPA regulates the use of ozone depleting substances, such as chlorofluorocarbons. No ozone depleting substances will be used in the melter design, processing, or in the trench.

5.3.11.3 Asbestos. Asbestos is a controlled respiratory carcinogen and trained and certified personnel must do all work involving asbestos-containing materials. No asbestos will be used ion the melter design, processing or disposal actions.

\subsubsection{Hanford Site Solid Waste Acceptance Criteria (HSSWAC)}

DOE Order 5820.2A requires that each treatment, storage, and/or disposal facility (referred to in this document as TSD unit) that manages low-level or transuranic waste (including mixed waste and TSCA PCB waste) maintain waste acceptance criteria. These criteria must address the various requirements to operate the TSD unit in compliance with applicable safety and environmental requirements. 
The criteria for each TSD unit have been established to ensure that waste accepted can be managed in a manner that is within the operating requirements of the unit, including environmental regulations, DOE Orders, permits, technical safety requirements, waste analysis plans, performance assessments, and other applicable requirements.

Specific waste streams could have additional requirements based on the identified TSD pathway.

Table 12 shows the necessary activities, along with cost and schedule estimates, to comply with performance assessment and composite analysis requirements.

Table 12. Cost and Schedule Estimates Waste Acceptance Criteria.

\begin{tabular}{|l|l|l|}
\hline $\begin{array}{l}\text { Hanford Site Solid Waste Acceptance Criteria } \\
\text { (HSSWAC) }\end{array}$ & 0.2 FTE (non-ES) & 9 months \\
\hline Review and revise existing HSSWAC & Exempt -40 hours & \\
\hline
\end{tabular}

5.3.12.1 Alternatives for Satisfying HSSWAC Requirements. There are no alternatives that warrant consideration at this time.

5.3.12.2 Significant HSSWAC Issues. There are no significant HSSWAC issues identified at this time.

5.3.12.3 Recommended Approaches for Complying With HSSWAC. The HSSWAC should be reviewed to ensure that melter disposal is properly addressed. If changes are necessary the HSSWAC should be revised or an exception prepared as necessary.

\subsection{COST ESTIMATES}

Cost estimates have been prepared to support the methodology presented for the design of a Melter Disposal Trench for spent and failed melters from the vitrification facility. The estimate has been prepared to reflect the baseline case with the trench location in $200 \mathrm{E}$, use of the naval reactor compartment transporter and piping of the leachate to the LERF facility. Alternatives for trucking of the leachate to the LERF facility, usage of the Vitrification Transporter, leasing a new Transporter and to the purchase of a new dedicated Transporter have been included along with the baseline. Costs for the baseline and four alternatives are presented in Table 13.

\subsubsection{General Assumptions}

The following general assumptions are common to the cost estimates for all of the alternatives.

- All Construction costs have been escalated to reflect FY 2000 dollars. 
- Operating costs are assumed to be 12 years. FY 2006 - FY 2018.

- Construction costs are for the phase 1 of the operation to complete Melter Disposal by 2018.

- Construction costs include site clear and grub, cut and fill to rough grade, leachate collection liner system, and roadways. Construction costs exclude perimeter fencing, site drainage/storm control, site lighting, utilities, ops building, maintenance building, security/access control and transport vehicles. Assumed no conceptual design costs for road upgrades.

- Cost information for trench excavation, rail installation, liner and leachate collection system and piping of the leachate to LERF are based on previous estimates prepared by FFS for similar activities at Trench 94 (Naval Reactor Compartments), Alternatives for Immobilized Low Activity Waste Disposal and project W-519 Radioactive, Dangerous Liquid Effluent Transfer Lines.

- Operational Readiness Review cost information was taken from the Multi Year Work Plan (MYWP) for the Interim Storage of Low Activity Waste Project W-520. ORR covers the activities associated with Start-up \& Test, Performance Mgmt. Self Assessment, Perform Contractor ORR and Perform DOE-ORP ORR.

- The cost for the AGA's is based on three studies at .9 FTE per study for a 3-month duration.

- Project Plan assumes 2.5 FTE's for 6 years from Project initiation through Start-up. Assume the team is comprised of a Project Manager, Controls/Planning, Procurement, Quality Assurance and Clerical.

- Authorization Basis assumes 2 FTEs for 2-year duration that address the PSAR, SAR, ALARA and Performance Assessment.

\subsubsection{Degree of Accuracy}

For the preparation of costs for the baseline as well as the alternatives the spreadsheet reflects a combination of information used from definitive for the construction activities to preliminary for Development, Ops and Transportation. The accuracy associated with this type of cost preparation is $+/-20 \%$. 
Table 13. Melter Disposal Costs, Baseline and Alternative Options.

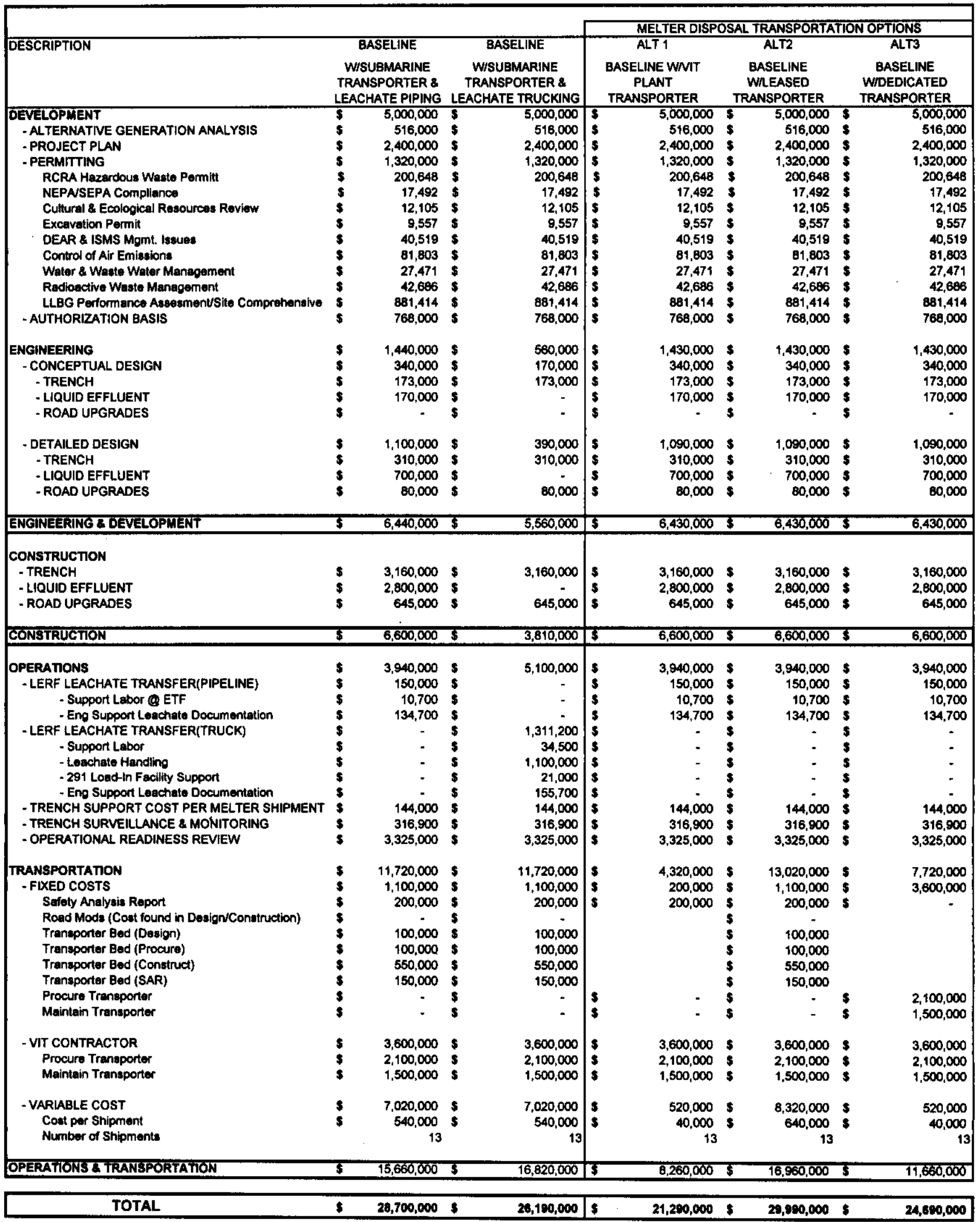




\section{RPP-7094 REV 0}

\subsection{SCHEDULE}

A schedule has been developed of activities necessary to begin receiving spent/failed melters into the new melter disposal trench by the assumed start date of October 1, 2006. The schedule, included in Appendix B, includes a number of alternatives generation analyses (AGA) to begin in FY2001. Critical path includes RCRA permitting, scheduled to begin in FY 2001 concurrent with the AGAs. Actual construction of the trench will begin in FY 2005. 


\subsection{CONCLUSIONS}

In order to meet the Vitrification Plant Hot Start up deadline, the Melters Disposal Project shall start early FY 2001.

The critical path of this project consists of the following.

- AGAs are to be performed early enough to enable decisions that will feed info/data to start conceptual and detailed design in due time and based on solid foundations. The Decisions-makers can apply a contingency planning for the project cost and schedule for the Critical Decision steps CD-2, -3, and -4 (see Appendix G, "Decision Analysis").

- The Permitting shall as well start in FY01 to give every info to the regulators needed for their approval and to feed conceptual and detailed design in due time with reliable data.

The Vitrification Plant operations will have a significant impact on the Melters Disposal, especially on its cost.The transportation cost is directly proportionnal to the quantity of spent/failed melters. In this document the cost is based on the 13 melters during Phase 1; in the Production chapter we think that a more realistic figure would be 19 melters, thus increasing the transportation cost by $50 \%$.

Another key aspect for the success of this project will be an absolutely strict and formal coordination with the Vitrification Contractor in most aspects of the project. 


\subsection{REFERENCES}

BNFL-5193-ID-03, Interface Control Document ICD-03 Between DOE and BNFL Inc. for Radioactive Solid Waste, Revision 5, BNFL Inc., Richland, Washington, 1999.

Burbank, D. A. Jr., and Calmus, R. B., 2000, River Protection Project Assumptions Relative to Disposition of Spent and Failed Melters from British Nuclear Fuels Limited, Inc. Vitrification Facilities, Revision 1a, Lockheed Martin Hanford Company, Richland, Washington.

DOE 435.1, Radioactive Waste Management, U.S. Department of Energy, Washington D.C., 1999.

DOE 460.1A, Packaging and Transportation Safety, U.S. Department of Energy.

DOE 5820.2A, Radioactive Waste Management, U.S. Department of Energy, Washington D.C., 1988.

DOE/EIS-0286D, Hanford Site Solid (Radioactive and Hazardous) Waste Program Environmental Impact Statement, Internal Working Draft, Pacific Northwest National Laboratory, Richland, Washington, December 1999.

HNF-EP-0063, Hanford Site Solid Waste Acceptance Criteria, Revision 5, Fluor Daniel Hanford Company, Richland, Washington, 1998. Available on the internet at http://www.hanford.gov/wastemgt/wac/index.htm .

HNF-PRO-157, Radioactive Material/Waste Shipments, Revision 0, Fluor Hanford, Richland, Washington, 1997.

L. Erickson, ORP to R. D. Hanson, FH, "Contract No. DE-AC06-96RL13200 - Assistant Manager for Waste Processing and Disposal (AMPD) Multi-Year Workplan (MYWP) Update Guidance For Fiscal Year (FY) 2000,” August 25, 1999.

PNNL-11800, Composite Analysis for Low-Level Waste Disposal in the 200 Area Plateau of the Hanford Site, C. T. Kincaid, et al., Pacific Northwest National Laboratory, Richland, Washington, 1998

WAC-173-303, Dangerous Waste Regulations, Washington State Department of Ecology, 1998.

WHC-SD-WM-TI-730, Performance Assessment for the Disposal of Low-Level Waste in the 200 East Area Burial Grounds, Revision 0, Westinghouse Hanford Company, Richland, Washington. 
RPP-7094 REV 0

APPENDIX A

A STUDY OF LEACHATE MANAGEMENT AT THE HANFORD SITE

A-i 
RPP-7094 REV 0

This page intentionally left blank.

A-ii 
RPP-7094 REV 0

\section{A STUDY OF LEACHATE MANAGEMENT AT THE HANFORD SITE}

\subsection{BACKGROUND INFORMATION}

\subsection{AREA LIQUID WASTE PROCESSING FACILITIES (LWPF)}

The Liquid Effluent Retention Facility (LERF) consists of three RCRA-compliant surface impoundments for temporarily storing process condensate from the 242-A Evaporator and other liquid wastes. The LERF provides equalization of the flow and $\mathrm{pH}$ of the feed to the ETF. Each LERF basin has a capacity of 7.8 million gallons. Spare capacity is maintained equal to the volume of one LERF basin as contingency in the event a leak should develop in an operational basin. The basins are constructed of two high-density polyethylene (HDPE) flexible membrane liners. A system is provided to detect, collect, and remove leachate from between the primary and secondary liners. Beneath the secondary liner is a 3-ft thick soil/bentonite barrier should the primary and secondary liners fail. Each basin has a mechanically-tensioned floating membrane cover constructed of very low-density polyethylene (VLDPE) to keep out unwanted material and to minimize evaporation of the basin contents. Also included in LERF are the direct, dedicated transfer lines and a valve manifold that contain and route liquid wastes to one of the three basins. The LERF began operation in April 1994 and has a 20 year design life.

Liquid wastes are treated in the Effluent Treatment Facility (ETF) to remove toxic metals and radionuclides, and destroy organics. The ETF treatment process constitutes Best Available Technology (BAT) and includes $\mathrm{pH}$ adjustment, filtration, ultraviolet light/peroxide (UV/OX) destruction of organics, reverse osmosis (RO), and ion exchange. Treatment capacity of the ETF is $150 \mathrm{gpm}$. Storage tanks allow for holdup of the treated effluent to allow verification that the waste has been treated to acceptable levels prior to discharge. The treated effluent is discharged under the WAC 173-216 State Waste Discharge Permit number ST 4500 to a State-Approved Land Disposal Site (SALDS) located north of the 200 West Area. Secondary waste from the ETF is concentrated and dried to a powder, that is packaged in drums and transferred to either the Central Waste Complex (CWC) for disposal in the Mixed Waste Trench, or to the Environmental Restoration Disposal Facility (ERDF). The ETF began operation in December 1995 and has a 30 year design life.

Operation of the ETF is subject to the requirements contained in DOE Orders, and is regulated under permits and approvals issued by the Washington State Department of Ecology (Ecology), Washington State Department of Health (WDOH), and the U.S. Environmental Protection Agency (EPA). The ETF can treat liquid wastes regulated under RCRA, CERCLA, or DOE Orders. The ETF can also treat liquid wastes that are not regulated under any of these programs (i.e., nonhazardous, nonradioactive). Because of the flexibility of the ETF, there are no facilityspecific acceptance criteria for inorganic or organic constituents except for radionuclides. Liquid waste acceptability is determined case-by-case based on concentration levels and volume. The Final Delisting for the ETF (40 CFR 261, Appendix IX, Table 2) identifies the specific waste codes for dangerous and mixed wastes that can be managed in the LERF and ETF. The Final Delisting allows for F001 through F005 listed wastes, and F039 leachate (derived from F001 
through F005) to be treated in the ETF. The State Waste Discharge Permit allows the ETF to accept generator effluents containing approved constituents at approved concentrations. The concentration levels are derived from characterization studies of previously approved effluents. Wastes having elevated concentrations of some constituents have been accepted into LERF only in small volume quantities. The wastes must then be treated to meet the discharge permit limits. Additional constraints on the liquid wastes that can be accepted for treatment are contained in the Nonradioactive Air Emissions NOC, Radioactive Air Emissions NOC, and the LERF and ETF Hazard Categorization/Auditable Safety Analyses.

The 291 Load-In Facility at the ETF allows liquid wastes to be received via tanker trucks and waste drums from other projects. A cross-site transfer system is used to transfer groundwater from the 200-UP-1 operable unit and ERDF leachate to the ETF for treatment.

Liquid wastes containing greater than $1 \%$ solids may be required to be filtered through a 5 micron (nominal) filter before receipt at the ETF. Additional filtration could be required if a significant amount of suspended solids remains after 5-micron filtration.

\subsection{TANK TRAILERS}

Waste Management has tank trailers available for use by a generating unit. The generating unit is responsible for the tank trailer at the time of release from the Waste Management facility until the tank trailer is accepted back at the Waste Management facility. The generating unit shall meet the applicable U.S. Department of Transportation (DOT) requirements of 49 CFR for transportation of a hazardous material if applicable. The generating unit is responsible to return the tank trailer in the same condition in which the tank trailer was released. If the tank trailer is not returned in the same condition, then the generating unit is responsible for restoring the tank trailer to its released condition. The scheduling of such restoration shall be negotiated between the generating unit and Waste Management.

The following tank trailers are available for transporting liquid wastes:

Beall tank trailers (2) - 8,000-gallon capacity

Polar tank trailers (3) - 5,000-gallon capacity

Walker tank trailer (1) - 5,000 gallon capacity

Superior tank trailer (1) - 1,000 gallon capacity

All the tank trailers are top fill design. The Beall tank trailers were just recently purchased, and have a sloped bottom and drain to facilitate cleaning.

\subsection{MIXED WASTE TRENCH LEACHATE}

The Mixed Waste Trench (Trench 34) is a RCRA-compliant Subtitle $C$ landfill (e.g., doublelined trench with leachate collection and removal system) and currently is operating under interim status. Trench 34 is used to dispose of mixed waste that has been treated to meet Land Disposal Restriction requirements. The collected leachate is managed as a mixed waste multisource leachate (F039) derived from listed dangerous waste numbers F001 through F005. 
Leachate from the Mixed Waste Trench is temporarily stored in a 10,000 gallon aboveground tank. The tank is surrounded by a concrete berm that is epoxy coated and has an HDPE liner. A concrete pad adjacent to the tank provides access for tanker trucks. The pad is curbed and measures approximately 20 feet wide by 100 feet long. The pad slopes to a sump, which has a capacity of about 200 gallons. The loadout pump used to transfer the leachate from the storage tank to tanker trucks is 500 gpm capacity. Trench 31 is similar in design to Trench 34 but is not currently used to dispose of mixed waste.

The Beall tank trailers are used to transfer the Mixed Waste Trench leachate to the 291 Load-In Facility at the ETF. Capacity of the Beall tank trailers is 8,000 gallons but the tank trailers have no level instrumentation. The volume of leachate transferred is procedurally limited to 7,000 gallons, and is determined by measuring the change in the volume of the leachate in the storage tank.

A larger tank is needed for storing leachate. The leachate can be stored for up to 90 days, but because the storage tank is undersized, it must be emptied quickly to make space available should more leachate be generated. A 24-hour, 25-year storm could possibly cause the allowable $1 \mathrm{ft}$ hydrostatic head on the trench liner to be exceeded because the leachate cannot be removed quickly enough. It is estimated that a 24-hour, 25-year storm could produce 127,000 gallons of leachate at the Mixed Waste Trench (RFSH 1996). A separate report estimated the average annual leachate production to be 155,000 gallons and the peak daily leachate production at 110,000 gallons (WHC 1994). The storage tank capacity is 10,000 gallons and it is possible to hold 10,000 gallons in the trench at just below $1 \mathrm{ft}$ hydrostatic head. Larger storage tanks may also reduce sampling costs. Leachate could be temporarily stored in tank trailers in an emergency.

A filter system is recommended for the leachate to prevent solids from getting in the tank trailers. The estimated cost of a filter system is $\$ 200 \mathrm{~K}$.

Baseline samples of the leachate are collected and analyzed for the constituents/parameters listed in Sampling and Analysis Plan for Trench 34 of the 218-W-5 Burial Ground. Thereafter every $20^{\text {th }}$ transfer is sampled and analyzed for total alpha, total beta, TOC, TSS, TDS, and pH. A1l leachate samples are collected and analyzed using RCRA protocol per EPA SW-846 test methods or equivalent. As a best management practice, every batch of leachate transferred from the trench to the aboveground storage tank is sampled for total alpha, total beta, and $\mathrm{pH}$. The Waste Sampling and Characterization Facility (WSCF) is the primary analytical laboratory for multi-source leachate analysis. The WSCF administrative limit for radiological dose rate of samples is less than $5 \mathrm{nCi} / \mathrm{g}$ or less than $5 \mathrm{nCi} / \mathrm{mL}$ for transuranics, and less than $5 \mathrm{mrem} / \mathrm{hr}$ at contact.

Before leachate transfers to the ETF can begin, the generator is required to provide physical, chemical, and radiological characterization data and complete a waste profile sheet. The generator is later required to perform verification sampling. Paperwork for each transfer includes a shipping manifest, which identifies the radioactive and hazardous constituents in the liquid waste, and the quantities. Engineering regularly contacts the generators to find out what liquid wastes are planned to be sent to ETF, and screens the characterization data to verify it fits the waste profile. Tanker trucks of leachate are unloaded at the 291 Load-In Facility and the 


\section{RPP-7094 REV 0}

contents either staged in Tank 109 or transferred directly to LERF. Operations then signs the paperwork and it is filed.

Labor required at the Mixed Waste Trench for each leachate transfer:

$1 \frac{1}{2}$ Operators for $4 \mathrm{hrs}(6 \mathrm{hrs}$ total) to load the tanker and sample the leachate COCS code WR05B - Nuclear Process Operator

Current rate from $\mathrm{P} 3$ is $\$ 55.36 / \mathrm{hr}$ fully burdened

$1 \mathrm{RCT}$ for $4 \mathrm{hrs}$ to take initial surveys and release the tanker for shipment COCS code WT05B - Health Physics Technician

Current rate from $\mathrm{P} 3$ is $\$ 53.90 / \mathrm{hr}$ fully burdened

1 Driver for $4 \mathrm{hrs}$

COCS code WL07B - Light Vehicle Driver

Current rate from $\mathrm{P} 3$ is $\$ 42.99 / \mathrm{hr}$ fully burdened

Additional costs at the Mixed Waste Trench associated with leachate handling:

2 Operators for $10 \mathrm{hrs}$ each week (1040 hrs/yr total) to manage the run-in liquid and remove accumulated sand and debris from the sump

COCS code WR05B - Nuclear Process Operator

Current rate from $\mathrm{P} 3$ is $\$ 55.36 / \mathrm{hr}$ fully burdened

$1 \mathrm{RCT}$ for $2 \mathrm{hrs}$ each week (104 hrs/yr total) for weekly surveillance of tank and sump COCS code WT05B - Health Physics Technician

Current rate from $\mathrm{P} 3$ is $\$ 53.90 / \mathrm{hr}$ fully burdened

FY 2000 spend forecast (FYSF) for sample analysis is $\$ 4400$

Rad screenings of leachate samples costs approximately $\$ 500$

Full characterization of the leachate every $20^{\text {th }}$ transfer costs approximately $\$ 8-10 \mathrm{~K}$

Samples of water in secondary containment after each rainfall. Estimate 20 samples/yr at $\$ 1,000$ each for analysis including certification and further analysis as required

Cost for tractor to pull the tank trailer is approximately $\$ 800 /$ month

The tank trailers are assigned to WMTS and there is no cost for using a tank trailer

Annual maintenance cost for tank trailer is $\$ 1900 / y$ for Testing, $\$ 600 / y r$ for DOT Inspection/Preventive Maintenance Service

Labor required at the 291 Load-In Facility for each leachate transfer:

1 Operator for 2 hrs to unload the tanker COCS code WR05B - Nuclear Process Operator

Current rate from $\mathrm{P} 3$ is $\$ 55.36 / \mathrm{hr}$ fully burdened

$1 \mathrm{RCT}$ for 2 hrs to monitor unloading, take surveys, and release the tanker for return trip COCS code WT05B - Health Physics Technician 
RPP-7094 REV 0

Current rate from $\mathrm{P} 3$ is $\$ 53.90 / \mathrm{hr}$ fully burdened

Additional costs at the ETF associated with liquid waste receipts:

1 Engineer at $0.1 \mathrm{FTE} / \mathrm{yr}$ for generator contacts and to review characterization data

\subsection{ERDF LEACHATE}

The Environmental Restoration Disposal Facility (ERDF) is designed to accept waste generated during the remediation of the 100,200, and 300 Areas of the Hanford Site. Wastes entering the ERDF are controlled based on source, classification, and contaminant levels. The facility accepts low-level radioactive waste, dangerous/hazardous waste, hazardous substances, and lowlevel mixed waste. These wastes originate from CERCLA past practice sites (i.e., operable units) in the 100 Areas, the 200 Areas, and the 300 Area of the Hanford Site. Remedial wastes, which will become a structural component of the ERDF, include bulk soil, demolition debris, and miscellaneous wastes from burial grounds.

The leachate storage tanks at ERDF can hold up to 500,000 gal of leachate. The storage tanks must be able to accommodate a 24-hr, 25-yr storm at any given time, which equates to 1.75 inches of rainfall over the landfill area. There are prescribed action levels for when leachate transfers have to be initiated. Leachate is pumped out of the storage tank, through a filter system, then transferred across the site directly to LERF. The leachate is typically transferred in batches of $100,000 \mathrm{gal}$ at a pumping rate of $250 \mathrm{gpm}$. A transfer takes about $7 \mathrm{hrs}$ and can be completed in one shift. The leachate is transferred to LERF via a tie-in to the Groundwater Transfer System, which is the same line as used for the 200-UP-1 groundwater. Groundwater pumping is suspended during leachate transfers. The filter system uses replaceable Micro-Kleen filter cartridges rated at 5 micron particle removal. Pressure drop across the filters is 2-3 psi. The filter housing is an ASME pressure vessel. Estimated cost of filter system is $\$ 20,000$. A flow meter and automatic sampler are also provided in the transfer line.

In 1996 ERDF had to transfer 1.5 million gal of leachate by tanker truck following a significant rainfall event. This took approximately 3 weeks working $24 \mathrm{hr} /$ day. Nearly all of the available storage space at ERDF for leachate was used. Now that leachate is being transferred by pipeline, transfers can be completed quickly and are no longer an issue.

Labor required at the LERF for each leachate transfer by pipeline:

1 Operator for $2 \mathrm{hrs}$ before the transfer for valve line-ups to direct the leachate into the desired LERF basin

1 Operator for $2 \mathrm{hrs}$ after the transfer to reset the valves

COCS code WR05B - Nuclear Process Operator

Current rate from $\mathrm{P} 3$ is $\$ 55.36 / \mathrm{hr}$ fully burdened

Filter system model number is ES-16-024-D-3-A-1-GA-E2-BB-A3

ES - Express Series housing

16 - 16 in. housing diameter 
024 - 24 filter cartridges

D - Double-open-end cartridge style

3 - 3 High cartridge height

A - Carbon steel materials

$1-150$ psi pressure rating

GA - Nitrile gasket material

E2 - Side $90^{\circ}$ outlet location

BB - Bolt cover bolt style

A3 - Side $270^{\circ}$ cover lifting device location

\subsection{PROJECT W-519 RADIOACTIVE, DANGEROUS LIQUID EFFLUENT TRANSFER LINES}

Project W-519 will construct and install three underground liquid waste transfer lines. Two lines, one primary and one backup, will transport an aqueous waste stream containing trace amounts of radioactive, dangerous liquid waste from the vitrification facility to the LERF. The primary line will tie into the existing LERF basin risers and manifold. The backup line will tie into the existing PC5000 line used to transfer process condensate from the 242-A Evaporator to the LERF. Both the primary and backup lines that transport radioactive, dangerous waste are fiberglass epoxy resin, double pipe containment systems. The brand name of the piping material is Ameron. The primary line consists of a 4-inch diameter carrier pipe within an 8-inch diameter containment pipe and is approximately 8,100 feet in length. The backup line consists of a 3-inch diameter carrier pipe within a 6-inch containment pipe and is approximately 4,000 feet in length. The pipelines are RCRA-compliant and have a continuous cable leak detection system able to locate a leak within a couple feet of the source.

The third transfer line will transport nonradioactive, nondangerous aqueous waste from the vitrification facility to the 200 Area Treated Effluent Disposal Facility (TEDF). The nonradioactive, nondangerous waste line consists of a 6-inch diameter single-wall PVC pipe approximately 4,000 feet in length.

All three lines will be buried in a common trench. The trench depth ranges between 3 and 10 feet, however the average depth over most of the trench will be 3 to 5 feet. All three pipelines are low pressure, gravity drained to their destinations and do not contain any in-line vents.

Project W-519 includes all the upgrades planned to the various infrastructure systems (i.e., electrical, raw and potable water, site development and roads, and liquid effluent transfer systems) to support the vitrification facility. Altogether the capital cost for the liquid effluent transfer systems included in Project W-519 (i.e., the two radioactive, dangerous lines and the one nonradioactive, nondangerous line) is approximately $\$ 3 \mathrm{M}$ for design and installation, which includes $\$ 300 \mathrm{~K}$ for engineering but no contingency. Costs for the construction management and project management of this portion of the project are estimated at $10 \%$ of the capital cost for the liquid effluents transfer systems.

Using the Project W-519 estimate as the basis, a rough order of magnitude (ROM) estimate of the capital cost for similar $4 \mathrm{~N} 8$ fiberglass pipe with continuous leak detection is $\$ 400$ per linear foot installed and tested. This includes engineering and inspection (engineering during 
construction, inspection, required $3^{\text {rd }}$ party inspection required), construction management, and project management with site adders. No specific allowance was made for contingency but the estimate is sufficiently high to cover contingency. The expense-funded project costs to support this construction (for safety, QA, environmental review/support, readiness review, startup, and testing) are estimated to be $\$ 60$ per linear foot. Design costs are not included as those would be specific to the location and line routing.

The cost of the nonradioactive, nondangerous liquid effluent line is $\$ 50$ per linear foot installed and tested. Including engineering and inspection, construction management, and project management the cost is $\$ 100$ per linear foot. Total cost of the nonradioactive, nondangerous liquid effluent line is $\$ 200-300 \mathrm{~K}$.

\subsection{2-S LABORATORY RADIOACTIVE LIQUID WASTE DRAIN LINES}

Laboratory liquid mixed wastes are normally transferred to tank farms for disposal via the 219-S Waste Handling Facility. Waste is sampled, analyzed, and neutralized prior to transfer to tank farms. The waste can then be transferred to a tank truck or transferred directly to tank farms via an underground double-encased pipeline.

Project W-087 installed two new radioactive liquid waste drain lines to serve the 222-S Laboratory. The project was split into two phases. Phase 1 provided the underground piping between 219-S and the 244-S receiver tank, and a transfer pump in one of the tanks in 219-S. Phase 2 connected the drains and such in 222-S to 219-S. The Phase 1 work scope was further split between construction forces work (Construction Specification W-087-C1) and fixed price contract (Construction Specification W-087-C2). The Phase 2 work scope was similarly split between construction forces (Construction Specification W-087-C3) and fixed price contract (Construction Specification W-087-C4).

Phase 1 of Project W- 087 cost about $\$ 8 \mathrm{M}$ and altogether about 6000 feet of underground piping was installed. The $\mathrm{Cl}$ work included excavation and backfill of approximately 500 lineal feet of trench, and furnishing and installation of approximately 1000 lineal feet of underground doublewall fiberglass piping (i.e., primary and spare drain lines at approximately 500 lineal feet each); installation of an air-operated diaphragm pump and associated equipment at 219-S to transfer the liquid waste at a flow rate of $125 \mathrm{gpm}$ and 100 feet total head; installation of instrumentation and controls at 219-S and 244-S; installation of piping and jumpers at 244-S; making tie-in connections to underground piping installed by others; performing hydrostatic and pneumatic testing of the installed piping; and installation of leak detection probes and controller panels. The $\mathrm{C} 2$ work included excavation and backfill of approximately 2500 lineal feet of trench, furnishing and installation of approximately 5000 lineal feet of underground double-wall fiberglass piping (primary and spare drain lines at approximately 2500 lineal feet each); performing hydrostatic and pneumatic testing of the installed piping; and installation of leak detection probes and controller panels.

The pipe code of the piping material used is $\mathrm{M}-17$ which specifies Fibercast dualcast double containment piping system using Centricast III carrier and containment pipe, or an approved substitute. Fibercast pipe was previously used for the piping between the 242-A Evaporator and LERF, and between LERF and ETF; there was a high incidence of joint failure during 


\section{RPP-7094 REV 0}

installation that caused a lot of re-work. For this reason, Ameron brand piping was substituted on Project W-087. Fiberglass piping was preferred because no cathodic protection is required, and because the chemistry of the wastewater is adjusted to meet tank farm specifications and has a pH of about 12. The pipe size is 3 N6 (i.e., 3-inch diameter carrier pipe inside 6-inch diameter containment pipe). The carrier pipe has a maximum operating pressure of $125 \mathrm{psig}$; the containment pipe is intended for atmospheric operation.

\subsection{SOURCES OF REQUIREMENTS}

- 40 CFR 264, "Standards for Owners and Operators of Hazardous Waste Treatment, Storage, and Disposal Facilities," Code of Federal Regulations, as amended.

Subpart J, Tank Systems

Section 264.193, Containment and Detection of Releases

Provides requirements for secondary containment systems and leak detection.

Subpart N--Landfills

Section 264.301--Design and Operating Requirements

Provides requirements for liners, and leachate collection and removal systems.

- 49 CFR 10-179, "U.S. Department of Transportation Hazardous Materials Transportation Regulations," Code of Federal Regulations, as amended.

- WAC 173-303, "Dangerous Waste Regulations," Washington Administrative Code, as amended.

WAC 173-303-180, Manifest

WAC 173-303-190, Preparing Dangerous Waste for Transport

WAC 173-303-200, Accumulating Dangerous Waste On-site

WAC 173-303-240, Requirements for Transporters of Dangerous Waste

WAC 173-303-250, Dangerous Waste Acceptance, Transport, and Delivery

WAC 173-303-260, Transporter Recordkeeping

WAC 173-303-270, Discharges During Transport

WAC 173-303-280, General Requirements for Dangerous Waste Management Facilities Provides requirements for registration, accumulation of waste for shipment, manifests for waste shipments, recordkeeping, and response to spills and discharges.

WAC 173-303-640, Tank Systems

Provides requirements for design and installation of new tank systems, containment and detection of releases, general operations.

WAC 173-303-665, Landfills

Provides requirements for liners, and leachate collection and removal systems. 
RPP-7094 REV 0

- DOE Manual 435.1-1, Radioactive Waste Management Manual, U.S. Department of Energy, Washington, D.C.

- DOE Order 6430.1A, General Design Criteria, U.S. Department of Energy, Washington, D.C.

Division 13--Special Facilities, Section 1300--General Requirements Section 1300-7.4, Transfer Pipes and Encasements

Provides requirements for secondary containment systems and leak detection.

Section 1300-8.2, Hazardous Waste Requirements

Applicability of RCRA to owners and operators of hazardous waste TSD facilities.

\subsection{ASSUMPTIONS}

\subsection{GENERAL}

The Melter Disposal Trench design will include: leachate collection system, leachate removal pump, leachate temporary storage tank, leachate transfer pump, and leachate filter system.

The Melter Disposal Trench leachate will be acceptable for treatment at the ETF.

\subsection{TANK TRUCK OPTION}

The 291 Load-in Facility at the ETF will be available to receive the Melter Disposal Trench leachate.

\subsection{PIPELINE OPTION}

The LERF will be available to receive the Melter Trench leachate.

\subsection{STRATEGY}

Acquiring a new trench for disposing of failed melters is a complex task. A systems engineering approach is recommended to be used. Systems engineering is a methodology used to develop technical solutions to large or complex problems. The process transforms an identified mission need into a set of performance parameters and a preferred system configuration. The approach includes the following steps: mission analysis, functional analysis, requirements identification and allocation, system synthesis, and alternative evaluation and optimization. Mission analysis 
provides a clear understanding of the problem and the project objectives. Functional analysis identifies the necessary and sufficient functions to be performed, and their interdependencies. Requirements identification is the systematic identification and allocation of requirements to each function, and provides the basis for comparing alternatives and limits the range of acceptable solutions. External requirements are placed on the project by outside sources and include laws and regulations, whereas mission-driven requirements impose performance and design constraints on the system. System synthesis defines the possible system(s) that meet the requirements and fulfill the mission. Alternative evaluation (i.e., engineering study) then uses trade studies, risk assessment, and cost/benefit analysis to arrive at a preferred solution. Together these related activities will establish the technical baseline for the new Melter Disposal Trench.

An engineering study is planned for FY 2001 that will evaluate alternative trench configurations. The study should address transportation of the leachate from the trench to the ETF. Life-cycle cost will be an important consideration in determining whether the leachate is transferred by tanker truck or pipeline. (Other factors include public and worker safety, environmental risk, regulatory compliance, and operability/maintainability of the leachate transfer system.) Costs for transporting the leachate will be driven by the location and size of the trench. Location of the trench determines the distance the leachate must be transported, while size of the trench determines the volume of leachate. The location chosen for the trench will be based upon proximity to waste streams and site characteristics. The size of the trench will depend on whether the trench is only for failed melters from the vitrification facility, or whether a large multi-use trench is needed to accommodate the waste disposal requirements of other site cleanup activities.

For the tanker truck option, plan to use the existing Beall tank trailers to transfer the Melter Disposal Trench leachate. Because of their larger size, the volume of leachate that can be transferred each trip is greater for approximately the same cost per trip. The smaller Polar tank trailers and the Walker tank trailer are available as backups if needed.

If a large multi-use trench in the 200 West Area is planned, then evaluate if tanker trucks can reasonably accommodate the amount of leachate that may be produced, particularly during a 24-hr, 25-yr storm. A cross-site pipeline for transferring leachate to the LERF may be justified (relative to large volume RCRA-compliant storage tanks for leachate awaiting transfer by tanker truck). A pipeline from 200 West Area to the LERF should consider tying in the leachate from the Mixed Waste Trench. Operating costs may be reduced by eliminating tanker truck transfers of the Mixed Waste Trench leachate. Concerns about insufficient leachate storage space would also be resolved. 
RPP-7094 REV 0

\subsection{REFERENCES}

FDNW 1994a, Construction Specification 222-S Radioactive Liquid Waste Line Replacement, W-087-C1, Revision 1, Fluor Daniel Northwest, Inc., April 1997.

FDNW 1994b, Construction Specification 222-S Radioactive Liquid Waste Line Replacement, W-087-C2, Revision 1, Fluor Daniel Northwest, Inc., April 1997.

RFSH 1996, Leachate Management for Mixed Waste Trenches, WHC-SD-WM-ER-626, Revision 0, Rust Federal Services, December 1996.

'WHC 1994, Design Report Project W-025 Radioactive Mixed Waste (RMW) Land Disposal Facility Non-Drag Off, WHC-SD-W025-FDR-001, Revision 1, Westinghouse Hanford Company, September 1994.

WMH 1998, Hanford Site Liquid Waste Acceptance Criteria, HNF-3172, Revision 0, Waste Management Federal Services of Hanford, Inc., September 1998.

WMH 1998, Functional Design Criteria for Project 93L-EWW-087, 222-S Radioactive Liquid Waste Line Replacement, Waste Management Hanford, June 1998. 


\section{RPP-7094 REV 0}

This page intentionally left blank. 
RPP-7094 REV 0

\section{APPENDIX B}

SCHEDULE OF ACTIVITIES IN PREPARATION FOR SPENT/FAILED MELTER DISPOSAL TRENCH 
RPP-7094 REV 0

This page intentionally left blank 
RPP-7094 REV 0

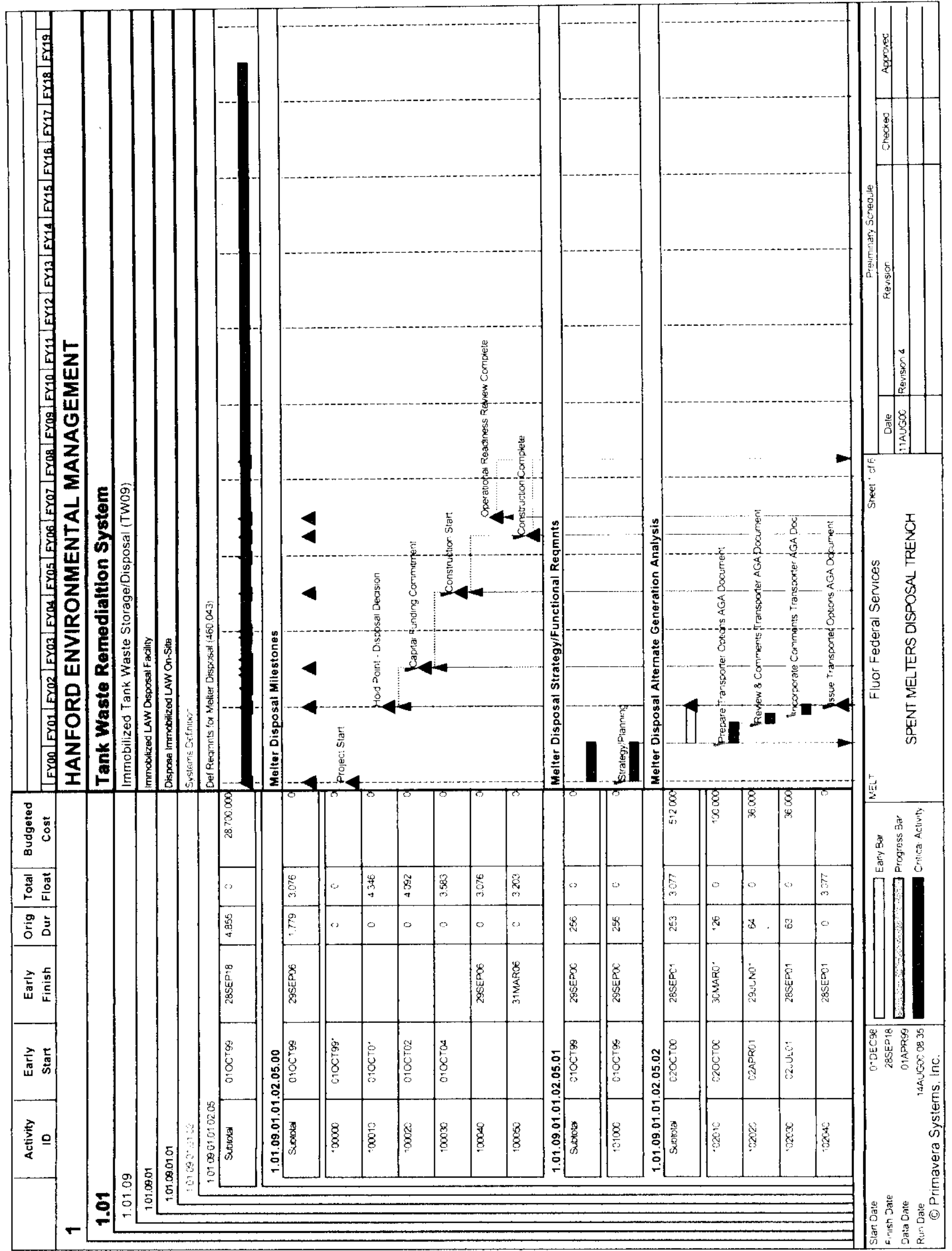


RPP-7094 REV 0

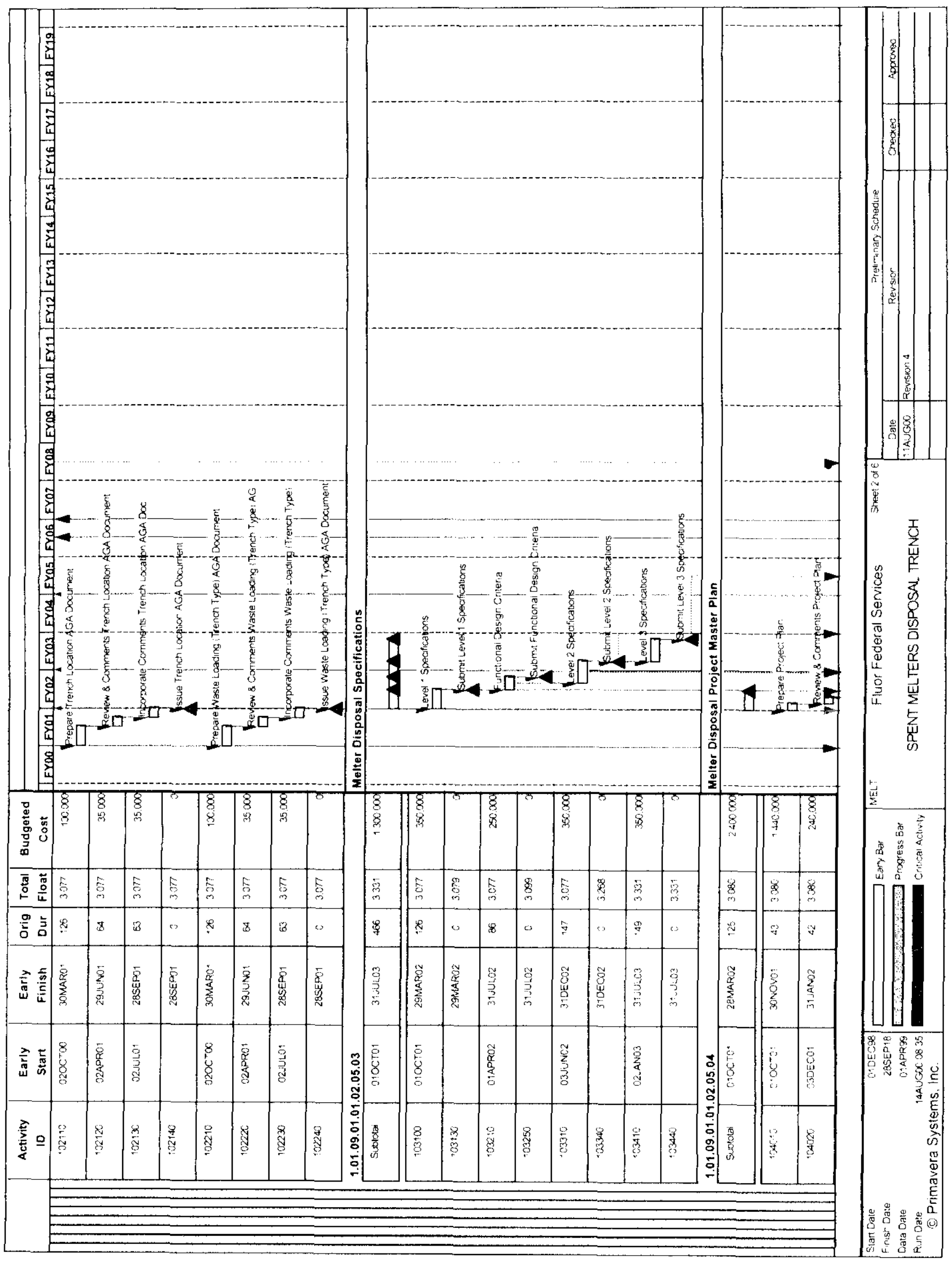

B-2 
RPP-7094 REV 0

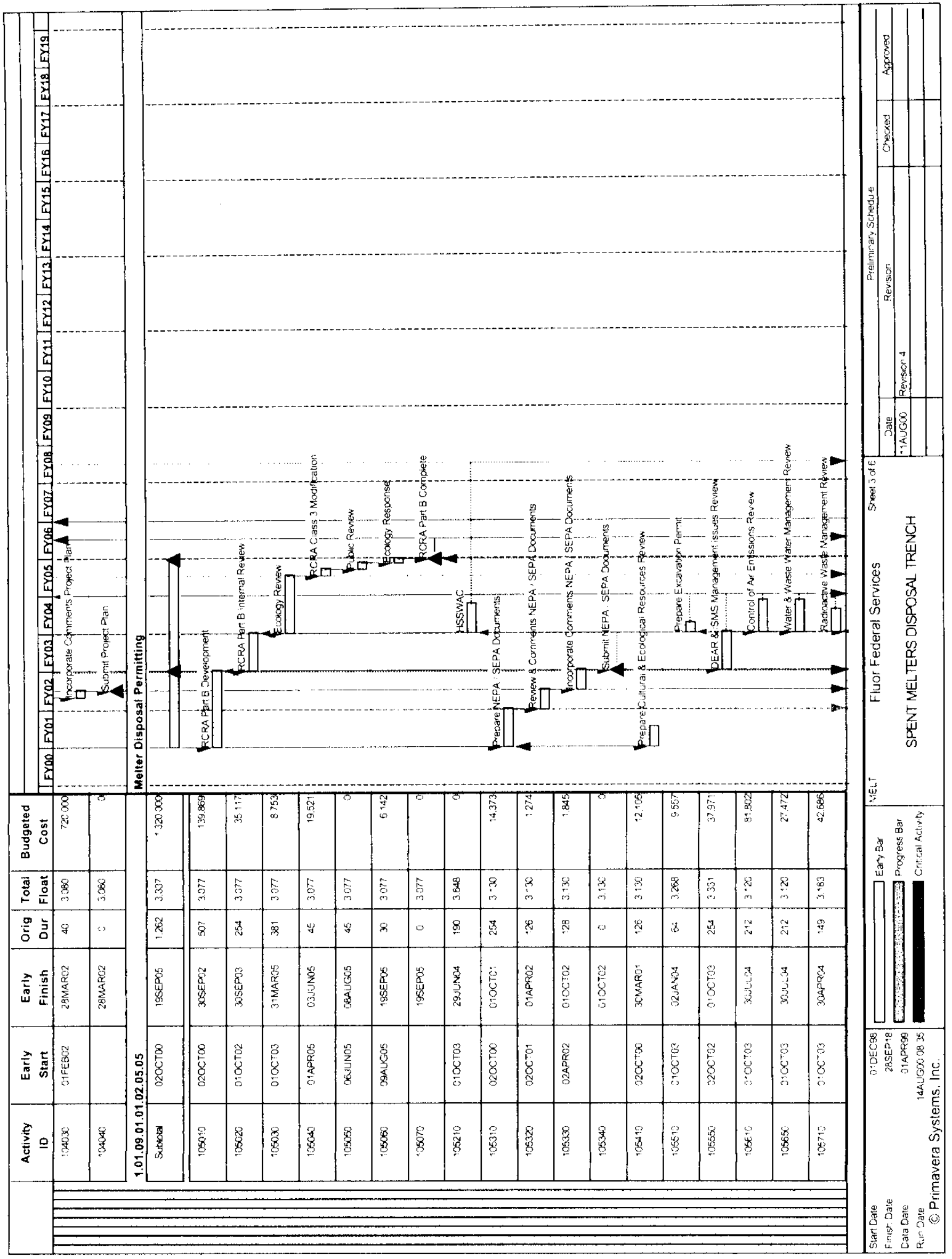

B-3 
RPP-7094 REV 0

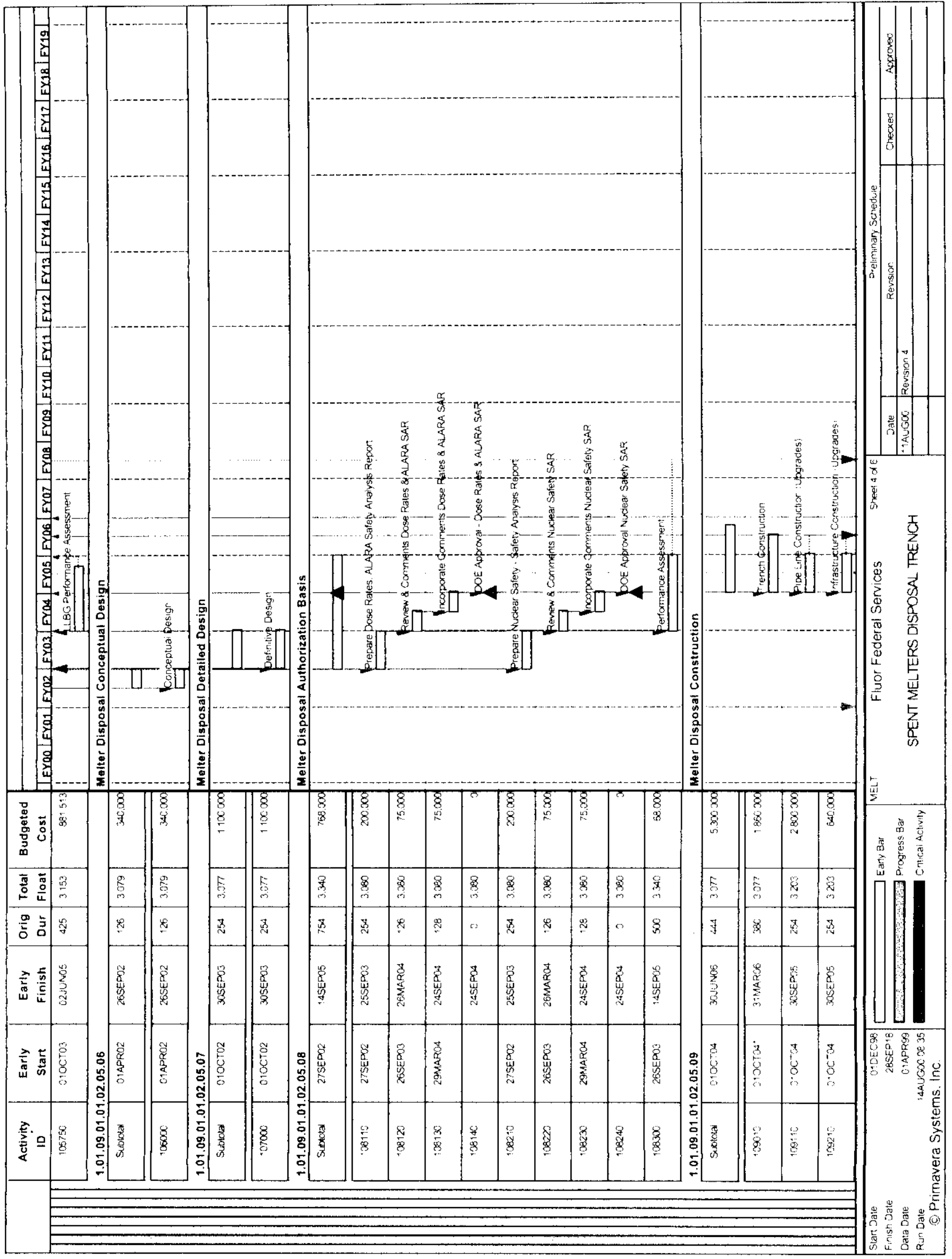


RPP-7094 REV 0

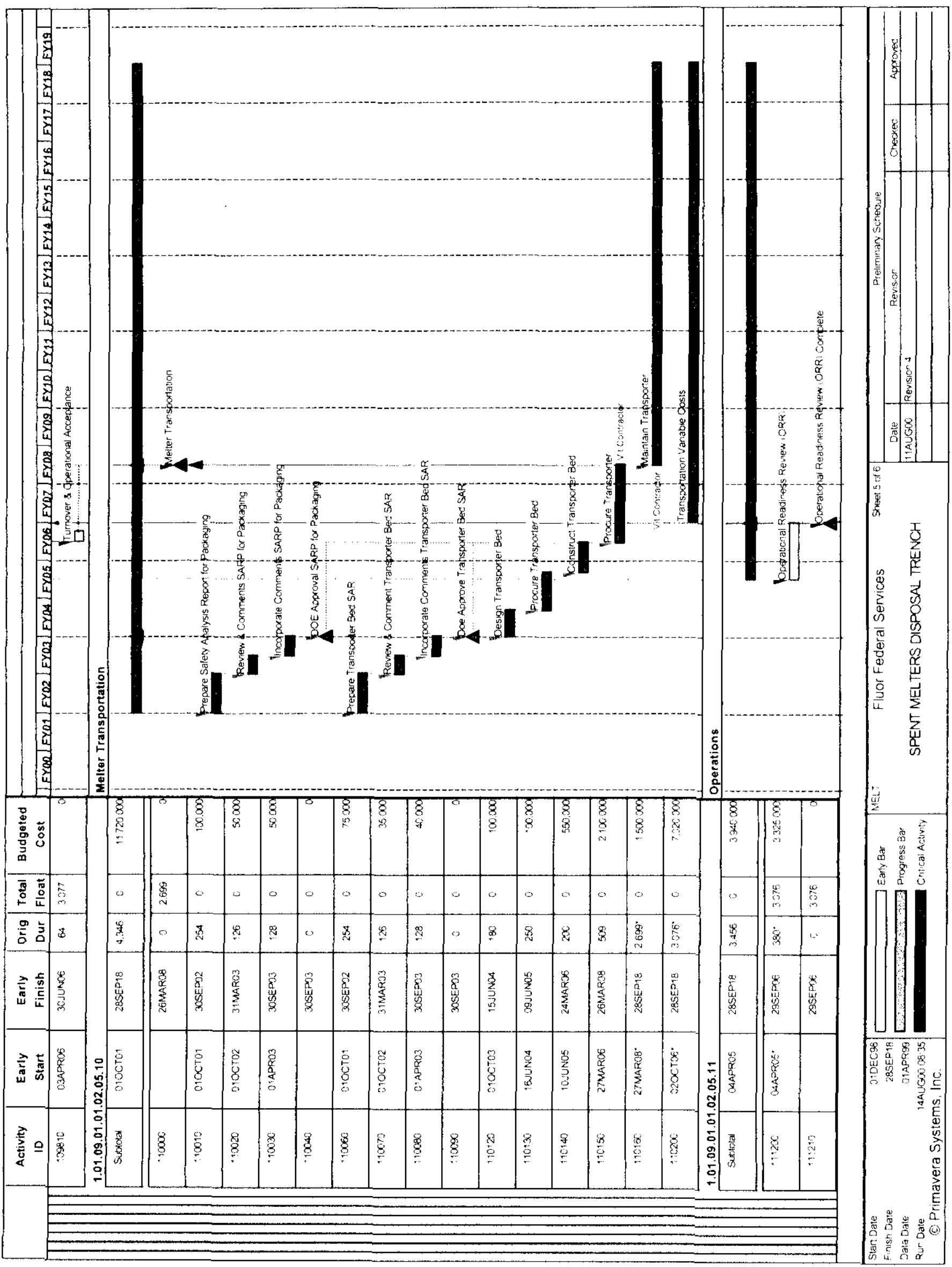

13-5 


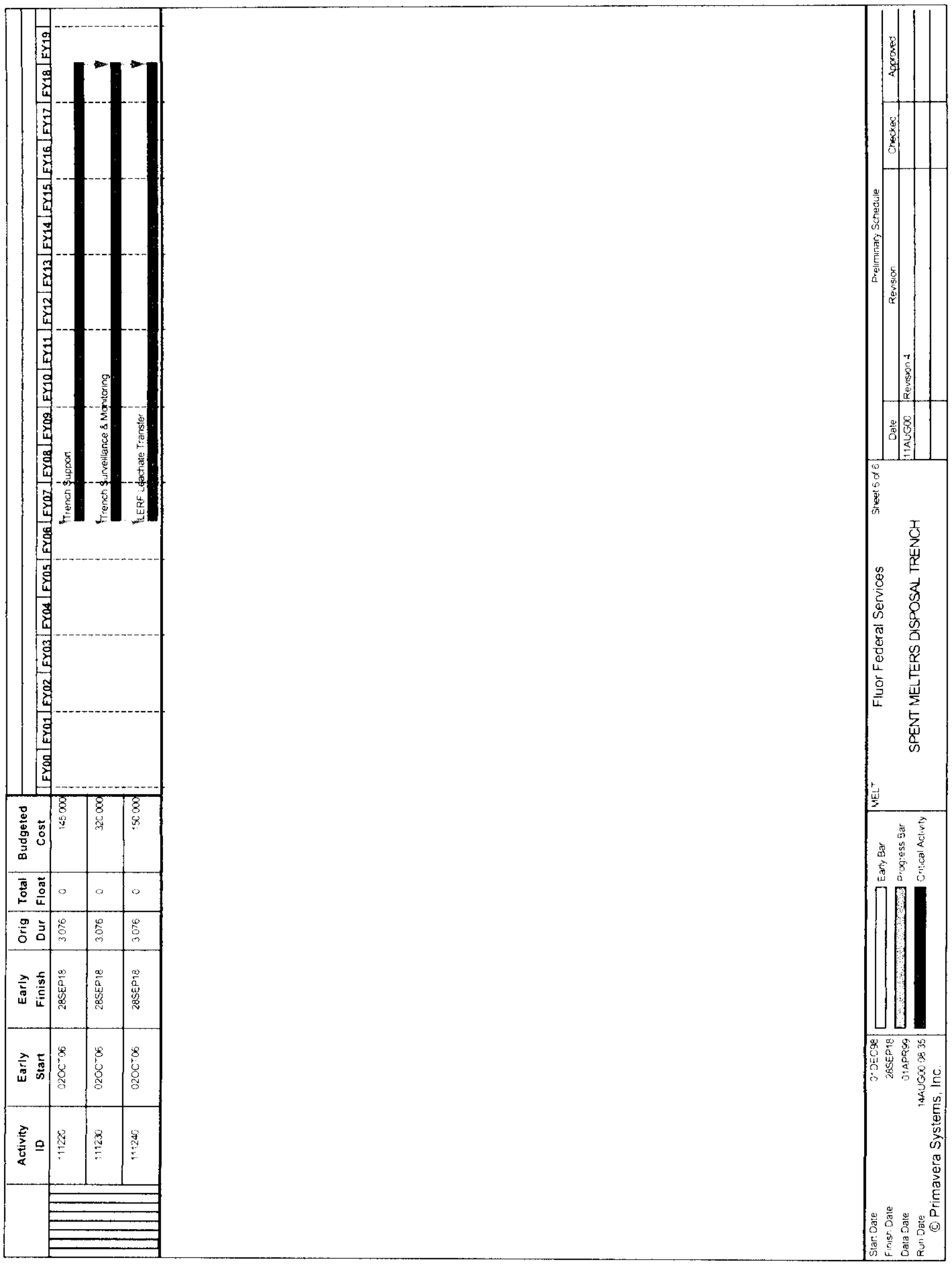

B-6 
RPP-7094 REV 0

\section{APPENDIX C}

PROJECTED PHASE 1 DISPOSAL RATES FOR FAILED MELTERS 


\section{PROJECTED PHASE 1 DISPOSAL RATES FOR FAILED MELTERS}

The objective of this task was to develop confidence intervals for the expected number of failed melters that will require disposal during Phase 1 of the tank waste treatment program. Two scenarios were analyzed.

\section{Scenario 1:}

The projected life of LAW and HLW melters is three years (ref: Burbank and Calmus, March 2000). A triangular melter life distribution was assumed with a minimum value of 1 year, a mode of 3 years, and a maximum value of 5 years. All melter failures were generated using this single distribution.

The $95 \%$ confidence interval for this scenario based on 100 replications of the statistical model is $15.4<\mathrm{u}<15.8$ melters. The average over the 13 years of Phase 1 is 15.6 failed melters.

The data used to develop the confidence intervals for Scenario 1 is summarized in Attachment 1.

\section{Scenario 2:}

PNNL-1 1014 discusses three possible failure modes for melters: failure mode 1- temperature too low, failure mode 2 - temperature too high, and failure mode 3 - max current exceeded.

PNNL 11014 also suggests triangular distributions for the expected life of a melter under each of these three failure modes.

Mode 1 - Low temp: $\quad \operatorname{Min}=1.1$ Mode $=2.2 \operatorname{Max}=8.8$ years

Mode 2 - High temp: $\quad \operatorname{Min}=0.4$ Mode $=0.8$ Max $=3.1$ years

Mode 3-Max Current: $\operatorname{Min}=0.7$ Mode $=1.4 \quad \mathrm{Max}=5.4$ years

For the purpose of this analysis, the three failure modes were considered to be equally likely; i.e., each of the distributions was used to generate, on average, one-third of the failures.

Based on 100 replications, the $95 \%$ confidence interval for number of failures is $18<u<19.2$ failed melters. The average over the 13 years of Phase 1 is 18.6 failed melters.

The data used to develop the confidence intervals for Scenario 2 is summarized in Attachment 2.

Note: These results are preliminary. A peer review by domain experts should be conducted to validate the assumptions and logic used to develop the failure distributions. A statistician should also peer review the statistical assumptions. 


\section{RPP-7094 REV 0}

\section{Next steps.}

Additional work will include evaluation of the interfaces with the melter transporter and waste disposal personnel and equipment. The following is a brief description of the primary tasks involved and an estimate of man-hours required for each of these tasks.

Task 1: Conduct a literature search to support data development for failure modes, failure time distributions, transporter options, disposal procedures, etc.

1 man-month.

Task 2: Develop algorithms, validate and document assumptions, analyze interfaces, and document results.

4 man-months.

Task 3: Peer review algorithms and assumptions.

1 man-month

Total $=6$ man-months.

\section{Attachment 1 -- Scenario 1:}

$95 \%$ Confidence Interval $=15.4<\mathrm{u}<15.8$ failed melters

Confidence interval on expected number of failures over thirteen years of Phase 1. Based on the projected average melter life of 3 years; the following triangular distribution was assumed for LAW and HLW melter life.

$\operatorname{Min}=1$ Mode $=3$ Max $=5$ years

$95 \%$ Confidence Interval Summary

$\begin{array}{ccccccc} & \text { AVERAGE } & \text { STANDARD } & .95 \mathrm{CI} & \text { MIN } & \text { MAX } & \text { NUMBER } \\ & & \text { DEVIATION } & \text { HALF-WIDTH } & \text { VALUE } & \text { VALUE } & \text { OF REPS. } \\ \text { COUNT_FAILURES } & 15.6 & 1.2 & 0.2 & 12 & 18 & 100\end{array}$

Histogram Summary for COUNT_FAILURES(100 replications)

$\begin{array}{ccc} & \text { \# Failed } & \text { Frequency } \\ \text { Cell } & \text { Melters } & \\ 1 & <12 & 0 \\ 2 & 12 & 2 \\ 3 & 13 & 2 \\ 4 & 14 & 1 \\ 5 & 15 & 29 \\ 6 & 16 & 33\end{array}$




$\begin{array}{rrr}7 & 17 & 19 \\ 8 & 18 & 3 \\ 9 & >18 & 0\end{array}$

\section{Scenario 1: Single Failure Mode}

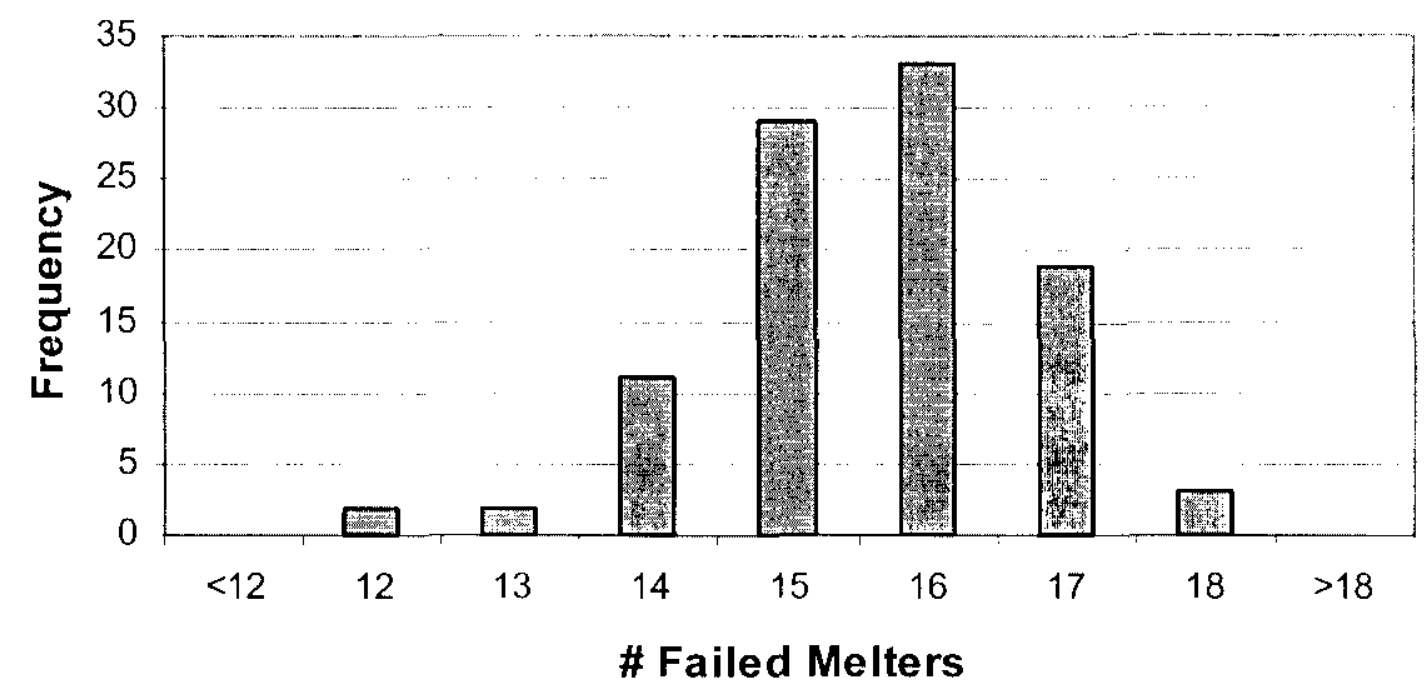

\section{Attachment 2 -- Scenario 2}

$95 \%$ Confidence Interval $=18.0<\mathrm{u}<19.2$ failed melters.

Three failure modes each of which are equally likely, triangular distributions to represent melter life for each failure mode.

Low temp: $\operatorname{Min}=1.1$ Mode $=2.2 \quad$ Max $=8.8$ ycars

High temp: Min $=0.4$ Mode $=0.8$ Max $=3.1$ years

Current: $\quad$ Min $=0.7$ Mode $=1.4 \quad$ Max $=5.4$ years

$95 \%$ Confidence Interval Summary

$\begin{array}{llcccc}\text { AVERAGE } & \text { STANDARD } & .95 \mathrm{CI} & \text { MIN } & \text { MAX } & \text { NUMBER } \\ & \text { DEVIATION } & \text { HALF-WIDTH } & \text { VALUE } & \text { VALUE } & \text { OF REPS. }\end{array}$

$\begin{array}{lllllll}\text { COUNT_FAILURES } & 18.6 & 2.8 & 0.6 & 14 & 26 & 100\end{array}$

Histogram Summary COUNT_FAILURES (100 reptications)

Cell Melters 


$\begin{array}{crr}1 & <14 & 0 \\ 2 & 14 & 7 \\ 3 & 15 & 7 \\ 4 & 16 & 12 \\ 5 & 17 & 10 \\ 6 & 18 & 16 \\ 7 & 19 & 11 \\ 8 & 20 & 12 \\ 9 & 21 & 8 \\ 10 & 22 & 8 \\ 11 & 23 & 2 \\ 12 & 24 & 4 \\ 13 & 25 & 1 \\ 14 & 26 & 1 \\ 15 & >26 & 0\end{array}$

\section{Scenario 2: Three Failure Modes}

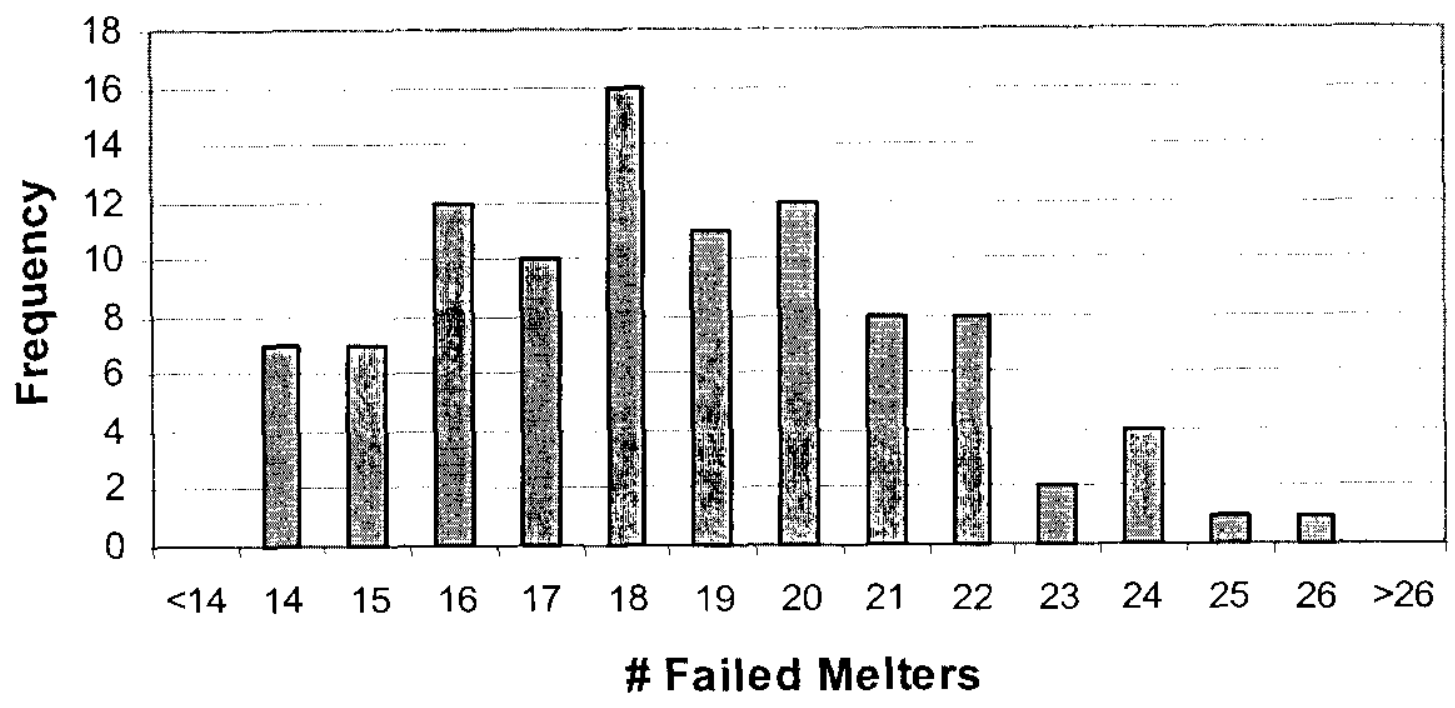


Attachment 3.-Single Year Failure
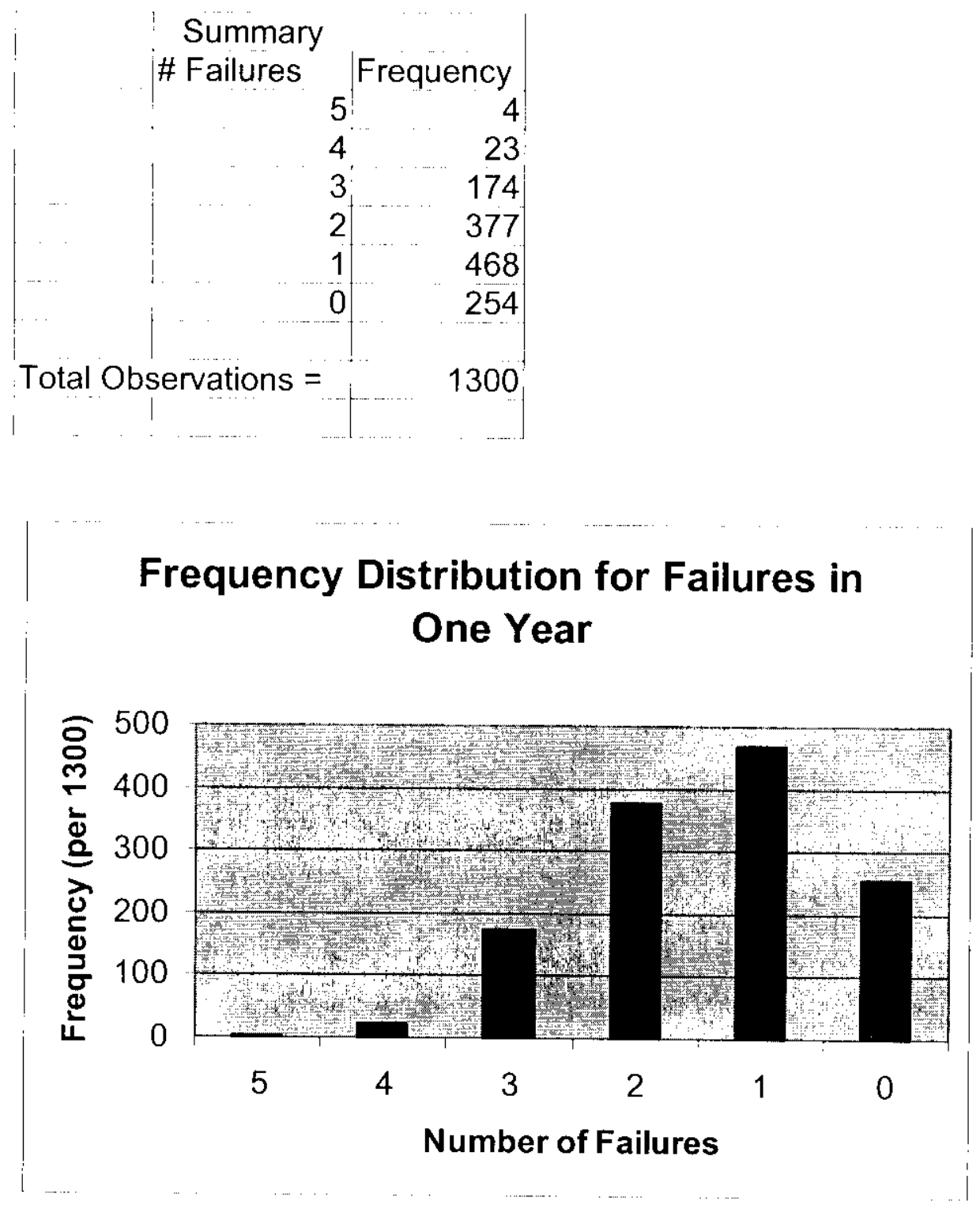
RPP-7094 REV 0

\section{APPENDIX D}

HIGH LEVEL WASTE (HLW) MELTER AND LOW ACTIVITY

WASTE (LAW) MELTER TRANSPORTATION FROM

THE VITRIFICATION FACILITY TO

THE DISPOSAL TRENCH

D-i 
RPP-7094 REV 0

This page intentionally left blank.

D-ii 


\section{HIGH LEVEL WASTE (HLW) MELTER AND LOW ACTIVITY WASTE (LAW) MELTER TRANSPORTATION FROM THE VITRIFICATION FACILITY TO THE DISPOSAL TRENCH}

\section{INTRODUCTION}

Waste Management Technical Services (WMTS) has been contracted by CH2M Hill Hanford Group (CHG) to provide transportation logistical expertise for movement of Low Activity Waste (LAW) melters and High Level Waste (HLW) melters from vitrification streams at the vitrification facility to a trench specifically designed for burial (disposal) of the melters. The burial trench will be located on the Hanford Site either in the 200 East Area near the Effluent Treatment.Facility (ETF) or in the 200 West Area at an optimal location.

The melters and the vitrification process are still in the design phase and many assumptions must be made relative to their design such as burial trench design, and melter transportation methodology to the burial trench. In addition, DOE is now considering alternate contracting approaches which may influence design decisions.

The start date for operation of the disposal trench is February 1, 2006. Hot operations of the HLW vitrification facility are scheduled to begin February 1, 2007. It is assumed that operation of the LAW facility will begin approximately the same time. The assumption has been made that three LAW lines and one HLW line will be in operation. There is, however, the possibility that additional LAW lines may be added to the facility. The spent melters are to be Category 3 waste bounded by HNF-EP-0063, Hanford Site Solid Waste Acceptance Criteria, Table A-2 Low Level Burial Grounds Radiological Content Limits, and contact handled for disposal.

The projected life of a melter is approximately three years. An assumption has been made, that as a bounding case, one to two melters will be disposed of each year. A cool down period of approximately two weeks is needed prior to transport to the disposal trench, with an anticipated 45 days of advance notice to be received by the waste management contractor prior to transport.

The approximate weight of each melter is 810 tons (assumed to be the weight of the LAW melter). The HLW melter is approximately 400 tons. The dimensions of each melter are approximately 26 feet ( 8 meters) long by 16.5 feet ( 5 meters) high by 16.5 feet ( 5 meters) wide.

An effective methodology is needed to transport failed melters to the disposal trench. The purpose of this study is to analyze several different transportation options and propose one of the options as the most effective solution.

\section{OBJECT}

The object of this analysis is to determine using the options listed below, which option is the most effective solution for transportation of failed melters to the disposal trench:

Option 1 - lease and use the existing naval reactor compartment transporter. 


\section{RPP-7094 REV 0}

Option 2 - use of the vitrification plant facility transporter from the building to the disposal trench.

Option 3 - use of a leased transporter other than the transporter used for naval reactor compartments.

Option 4 - procurement of a dedicated transporter system.

\section{TRANSPORTATION SAFETY}

Movement of the melters from the facility to the disposal trench requires safety basis documentation. It is assumed that the melters, in a configuration for transport (melter in overpack), will not be in compliance with Department of Transportation (DOT) Regulations. Therefore, in accordance with DOE-RL direction, equivalent safety to DOT Regulations is required. The basis for establishing equivalent safety to DOT Regulations using certain restrictions, administrative controls, and analysis of package safety is provided in a Onsite Safety Analysis Report for Packaging (SARP). The analysis of the payload will establish the authorization of the activity limits, procedures, controls, and restrictions acceptable for achievement of equivalent safety to DOT Regulations. Dose rates and contamination levels associated with the melter package and the transporter utilized will be in accordance with DOT limitations or limitations specified in the SARP.

As a minimum, one (1) SARP will be needed to document the safety of the packaging and transportation system and configuration for both the LAW melter and HLW melter. Regardless of which of the four (4) options is used, the following cost and schedule will apply (one time) and must be completed and approved prior to the first shipment of a melter to the disposal trench.

\section{Schedule}

1 to 2 years to complete an Onsite SARP.

\section{Cost}

$\$ 150,000.00$ to $\$ 200,000.00$ to complete the SARP.

\section{ANALYSIS}

Option 1 - Lease and use of the existing naval reactor compartment transporter is the most acceptable option available at this time. The transporter and ancillary equipment is in existence at the Hanford Site and can be scheduled for use around the naval reactor compartment movements.

The naval reactor compartment transporter and ancillary equipment are used to move naval reactor compartments to Trench 94 approximately 10 times a year ( 2 to 4 reactor compartments each spring, and 4 to 6 reactor compartments each fall). Water levels in the Columbia River, maintenance of Columbia River locks, and coastal waters provide prime operating conditions at 


\section{RPP-7094 REV 0}

these times. Therefore, it would be achievable to schedule failed melter movements around naval reactor compartment movements during the calendar year without impacting either melter movement schedule or naval reactor compartment movement schedules.

\section{Naval Reactor Compartment Transporter Shipment Schedule}

Movement of the melter from the facility (Vitrification Plant or storage area near the Vitrification Plant ) to the disposal trench will take 1 day.

Planning and mobilization will commence 30 days prior to transport. Note: This is worst case. Mobilization could take less time (as little as two weeks if equipment was available).

Demobilization will take approximately 30 days.

\section{Naval Reactor Compartment Transporter Shipment Cost}

The cost associated with this option is approximately $\$ 540,000.00$ per shipment. This approximate cost includes the utilization of the transporter and ancillary equipment and the service provider to operate and maintain the transporter and ancillary equipment (use of tractors, use of transporter lines, transporter mobilization efforts, transporter de-mobilization efforts, other materials as necessary, and associated maintenance). The approximate cost per shipment is broken down as follows.

$\$ 178,000.00$ for 1 each transporter. This includes cost for 60 days based on a schedule for mobilization with transporter frame fit up, use, and demobilization).

$\$ 42,000.00$ for 2 each prime movers (tractors). This includes cost for 60 days based on a schedule for mobilization, use, and demobilization.

$\$ 290,000.00$ for service provider engineering, crafts, labor, and other support personnel and systems.

$\$ 30,000.00$ of Hanford Site cost for engineering, crafts, labor, and other support personnel and systems. This includes a planning phase of 30 to 60 days prior to transport.

This option is far less expensive than procurement of dedicated equipment (Option 4) since the equipment is already onsite and the contractor supplying services is nearby. This transporter can be used to transport directly from the facility to the disposal trench, or from the staging area near the facility to the disposal trench. In addition, use of this transporter is far less expensive than leasing a dedicated transporter (Option 3). Leasing dedicated equipment will cost approximately $\$ 640,000.00$ per shipment due to additional mobilization and de-mobilization costs for the dedicated transporter (Option 3).

Current plans for entry and exit of the disposal trench are similar in design, grade, width, and length to the naval reactor compartment trench where the transporter is currently utilized. The existing naval reactor compartment transporter and ancillary equipment would be ideal for entry into the melter disposal trench and exit based on current plans. The total length of the transporter system (including prime movers is approximately 226 feet ( 69 meters). The transporter system carries 22 lines of tires with a length of 116 feet (36 meters) long by 24 feet ( 8 meters) wide by 4 feet ( 1.2 meters) high. The inside turning radius is 40 feet ( 12 meters). The outside turning radius is 101 feet ( 31 meters). The transporter system utilizes prime movers (tractors) on each end enabling the transporter to be pushed into the disposal trench while loaded 
and positioned so the melter can be unloaded onto a platform similar to that utilized at the facility melter staging area. The facility utilizes a platform with Teflon rails and a motorized system to drag the melter on the rails horizontally from the facility or facility staging area platform onto the transporter. Once unloaded, movement of the transporter is accomplished by pushing or pulling it out of the trench.

The naval reactor compartment transporter may require some modification to accommodate the two different melters due to the size and weight difference (HLW melter weighs approximately 400 tons, LAW melter weighs approximately 810 tons). In addition, modifications will be needed to accommodate use of the facility rail system and the use of a rail system on the platform in the disposal trench.

The one time cost for modification of the transporter is projected to be approximately $\$ 900,000.00$ to complete. The approximate schedule and approximate costs for modification are broken down as follows.

\section{Naval Reactor Compartment Transporter Modification Schedule (One Time)}

One (1) year to complete modifications (prior to initial transport).

\section{Naval Reactor Compartment Transporter Modification Cost (One Time)}

$\$ 100,000.00$ for design modifications.

$\$ 150,000.00$ for safety basis analysis and safety basis documentation. $\$ 100,000.00$ for procurement of materials and/or fabrication.

$\$ 500,000.00$ for fit up and actual modification of the transporter (approximately 50 tons of material at $\$ 5.00 /$ pound).

$\$ 50,000.00$ for oversight, including safety and other organizations.

The existing transporter is capable of transporting the 810 ton load. The grade limit suitable for transport into the disposal trench is approximately $5 \%$, similar for entry into the naval reactor compartment trench.

The existing transporter can be utilized on current Hanford Site paved roads and/or bladed gravel roads since it has rubber tires and weight is distributed using multiple axles. The velocity of transport will be up to $5 \mathrm{mph}$. If transfer lines are crossed and/or it is deemed that strengthening of existing roads is needed, an evaluation will be done on a case by case basis. Upgrade of a roadway from the Vitrification Plant to the proposed disposal trench at the unused northwest corner of the 218-E-12B Burial Grounds (a distance of approximately 1.7 miles) will cost approximately $\$ 725,000.00$ to complete(assumes a window of 60 days to complete). This assumes re-paving and widening the road (12th Street) to a minimum of 24 feet, with 3 foot shoulders.

\section{Option 2 - Use of the vitrification plant facility transporter from the building to the}

disposal trench may be a viable option as well. The drawings for the facility transporter are at this point in time are preliminary. The facility transporter is designed to mate up with the facility from the side to accommodate loading of the HLW melter, and from the front/rear for LAW melter. The melter inside the over pack may be dragged onto the facility transporter horizontally using a motorized system. Note that there are currently no pick points to lift either the HLW or LAW melter onto the transporter. The melter is dragged onto the facility transporter via a rail 
system mated up to the facility (same height). The transporter must be able to adjust in height approximately 12 inches to accommodate the melter load. In addition, the transporter deck is intended to be fitted with an additional deck used when transporting the HLW melter.

The total length of the transporter system including the prime movers is approximately 152 feet ( 47 meters). The designed transporter is 42 feet ( 13 meters) long by 24 feet ( 8 meters) wide by 6 feet ( 2 meters) high and weighs approximately 38 tons. The transporter is an 8 to 10 line system that is designed to be pushed or pulled (possibly from either end) by a multiple axle prime mover. The inside turning radius is assumed to be approximately 15 feet ( 5 meters). The outside turning radius is assumed to be approximately 40 feet ( 13 meters). The velocity of transport is $3 \mathrm{mph}$.

The grade limit for transport of the HLW melter is $3 \%$. The grade limit for transport of the LAW melter is $2 \%$ or less. These grade limits would have to be applied to entry of the disposal trench. This could increase the disposal trench foot print and costs for design and construction of the disposal trench.

The facility transporter should be able to be utilized on current Hanford Site paved roads and/or bladed gravel roads since it has rubber tires and weight is distributed using multiple axles. If transfer lines are crossed and/or it is deemed that strengthening of existing roads is needed, an evaluation will be done on a case by case basis. Upgrade of a roadway from the Vitrification Plant to the proposed disposal trench at the unused northwest corner of the 218-E-12B Burial Grounds (a distance of approximately 1.7 miles) will cost approximately $\$ 725,000.00$ to complete (assumes a window of 60 days to complete). This assumes re-paving and widening the road (12th Street) to a minimum of 24 feet, with 3 foot shoulders.

The storage platform in the disposal trench could be designed to accommodate trans-loading the melters onto the platform via a similar motorized system. The disposal trench platform would mate up to the transporter for trans-loading. Cost figures are currently unavailable for the facility transporter system due to legal concerns associated with the vitrification contract. It is, however, assumed that utilization of this transporter, including maintenance costs would be substantially lower over the life time of the project compared to duplicating the cost in leasing or procurement of a second transporter for movement of the melters from the facility staging area to the disposal trench.

This option could be by far the best option given vendor information that assumes $\$ 2,100,000.00$ for procurement (transporter, prime movers, ancillary equipment)and $\$ 1,500,000.00$ in maintenance over the project life time (approximately 12 years) (consistent with Option 4). In addition, storage platforms in the disposal trench can be patterned after the storage platform and facility for consistency (i.e., motorized system for movement from the transporter onto the trench platform). The approximate schedule and cost for procurement of the transporter is as follows. 


\section{Facility Transporter Procurement Schedule}

One (1) to two (2) years to complete procurement and delivery prior to initial transport.

\section{Facility Transporter Procurement Cost}

Transporter approximately $\$ 1,500,000.00$

Two prime movers approximately $\$ 500,000.00$

Delivery to Hanford approximately $\$ 100,000.00$

The approximate onsite shipment schedule and cost per shipment is broken down as follows.

\section{Facility Transporter Shipment Schedule}

One (1) to two (2) days per shipment.

Planning phase (including equipment mobilization) begins 30 prior to transport.

30 days for demobilization.

\section{Facility Transporter Shipment Cost}

$\$ 40,000.00$ of Hanford Site cost for engineering, training of personnel in transporter operations, crafts, labor, and other support personnel and systems.

\section{Option 3 - Use of a leased transporter other than the transporter used for naval reactor} compartments is also a viable option. Transporter equipment available for use would be similar to the equipment used to transport the naval reactor compartments. The total length of the transporter system including the prime movers is approximately $194 \mathrm{ft}(59 \mathrm{~m})$. The transporter would carry 16 lines of tires with a length of $84 \mathrm{ft}(26 \mathrm{~m})$ by $24 \mathrm{ft}(8 \mathrm{~m})$ wide by $4 \mathrm{ft}(1.2 \mathrm{~m})$ high. The inside turning radius would be $30 \mathrm{ft}(10 \mathrm{~m})$. The outside turning radius would be $80 \mathrm{ft}$ $(25 \mathrm{~m})$. Removal of the melter from the transporter would be accomplished utilizing a modified transporter platform and motorized system. A similar system is needed to drag the melter onto the rails of the transporter and off the transporter onto the disposal platform.

Leasing dedicated equipment will cost approximately $\$ 640,000.00$ per shipment due to an additional $\$ 100,000.00$ mobilization and demobilization costs over and above that needed for the naval reactor compartment transporter system.

The approximate schedule and cost per shipment is broken down as follows.

\section{Leased Transporter Shipment Schedule}

Movement of the melter from the facility (Vitrification Plant or storage area near the Vitrification Plant ) to the disposal trench will take 1 day.

Planning and mobilization will commence 30 prior to transport. This is worst case. Mobilization could take less time (as little as two weeks if equipment was available).

Demobilization will take approximately 30 days. 
$\$ 278,000.00$ for 1 each transporter. This includes cost for 60 days based on a schedule for mobilization, use, and demobilization).

$\$ 42,000.00$ for 2 each prime movers (tractors). This includes cost for 60 days based on a schedule for mobilization, use, and demobilization.

$\$ 290,000.00$ for service provider engineering, crafts, labor, and other support personnel and systems.

$\$ 30,000.00$ of Hanford Site cost for engineering, crafts, labor, and other support personnel and systems. This includes a planning phase of 30 to 60 days prior to transport

The cost for modification of the transporter to accommodate the loading and unloading system is projected to be an additional $\$ 900,000.00$ to complete which is consistent with Option 1 above.

The approximate schedule and approximate costs for modification of the transporter for transport of the HLW and LAW failed melters are broken down as follows.

\section{Leased Transporter Modification Schedule (One Time)}

One (1) year to complete modifications (prior to initial transport).

\section{Leased Transporter Modification Cost (One Time)}

$\$ 100,000.00$ for design modifications.

$\$ 150,000.00$ for safety basis analysis and safety basis documentation.

$\$ 100,000.00$ for procurement of materials and/or fabrication.

$\$ 500,000.00$ for fit up and actual modification of the transporter.

$\$ 50,000.00$ for oversight, including safety and other organizations.

Upgrade of a roadway from the Vitrification Plant to the proposed disposal trench at the unused northwest corner of the 218-E-12B Burial Grounds (a distance of approximately 1.7 miles) will cost approximately $\$ 725,000.00$ to complete (assumes a window of 60 days to complete). This assumes re-paving and widening the road (12th street) to a minimum of $24 \mathrm{ft}$ with $3 \mathrm{ft}$ shoulders.

Option 4 - Procurement of a dedicated transporter system is the least desirable option. The transporter system would cost approximately $\$ 2,100.000 .00$ with a cost of $\$ 1,500,000.00$ in maintenance over the project lifetime (see Option 2 estimates above). This option potentially doubles the cost projected for use of the facility transporter (Option 2) since two transporters would be needed for movement of the melters (the facility transporter and the transporter for movement to the disposal trench).

Personnel would need to be trained in operations and maintenance activities to ensure the operability of the transporter system, in addition to operation and maintenance of the facility transporter. All design requirements for the transporter system must be consistent with the facility and disposal trench platforms. The transporter, training program, and maintenance program must be in place prior to initial operation of the transporter system. 
The approximate schedule and cost per shipment is broken down as follows.

\section{Dedicated Transporter Shipment Schedule}

One (1) to two (2) days per shipment.

Planning phase (including equipment mobilization) 30 days prior to transport.

30 days for demobilization

\section{Dedicated Transporter Shipment Cost}

$\$ 40,000.00$ of Hanford Site cost for engineering, training of personnel in transporter operations, crafts, labor, and other support personnel and systems.

\section{CONCLUSION}

Option 1 is the most effective solution to be utilized for melter transport to the disposal trench based on existing information and due to the availability of the existing transporter and close proximity of the transporter service provider. Capabilities of this transporter are known with the exception of details associated with modification to the transporter for melter loading and unloading (e.g., motorized system for dragging the melter to and from the transporter, platform modifications). The cost as indicated above is within the range between use of the facility transporter and procurement of a dedicated transporter for movement to the disposal trench.

Option 2 may prove to be the most desirable option over all if preliminary designs, budget, and schedule are adequately determined to establish the need for only one transporter system. In addition, Option 2 would be the most desirable option if no requirement is imposed to stage the transporter in the facility area (i.e., transport melters directly to the disposal trench), and no requirement establishes a need to operate and maintain the facility transporter within the facility boundaries due to design or scheduling concerns.

Option 3 is comparable to Option 1 with the same operating parameters. Additional cost for mobilization and de-mobilization makes this option less desirable than Option 1.

Option 4 should not be considered unless parameters not previously discussed or known require a second dedicated transporter system. 
RPP-7094 REV 0

APPENDIX E

MELTER DISPOSAL TRENCH DESIGN ASSUMPTIONS

E-i 
RPP-7094 REV 0

This page intentionally left blank.

E-ii 


\section{MELTER DISPOSAL TRENCH DESIGN ASSUMPTIONS}

\section{General:}

Assumptions:

1. This trench study/cost estimate is based on the construction costs for phase I of the operation. Further, this study will only evaluate "Improvements to the Land" including:

- Site clear and grub

- Cut and fill to rough grade

- Leachate Collection Liner System

- Roadways

And exclude consideration of:

- Perimeter fencing and signs

- Site drainage/storm water control

- Site Lighting

- Utilities

- Operations Buildings

- Maintenance Buildings

- Security/Access Control

- Transport vehicles

2. Excavation cost is assumed to be $\$ 1.25 / \mathrm{CY}$, based on the most recent Trench 94 excavation. This cost is for the excavation only, no adders, and based on the availability of an adjacent dumpsite.

3. No attempt has been made to bring the cost data to present or future dollars. All costs presented in this evaluation can be assumed to be sub-contractor bid FY 1997 dollars with no adders.

\section{Location:}

Assumptions:

1. The trench for both the LAW and HLW will be constructed in the unused north west corner of the 218-E-12B burial grounds.

2. The access to this site will be from the north off of $12^{\text {th }}$ Street.

3. The transport will travel to the trench site west bound on $12^{\text {th }}$ Street.

4. The transport will back-into the trench after passing the entrance.

5. The access road will be flared to the turning radius of the transport on both sides.

6. The access road will as short as possible. Assumed twice the length of the transport to allow maneuvering in and out on a level surface. Therefore, the ramp/trench entrance will be located 304-452ft. south of $12^{\text {th }}$ Street. 


\section{RPP-7094 REV 0}

\section{Site Clear and Grub:}

Assumptions:

1. The trench for both the LAW and HLW will be constructed in the unused north west corner of the 218-E-12B burial grounds.

2. A $766,000-855,000$ sf area will be cleared and grubbed to facilitate construction

3. The clear and grub costs will be similar per square foot to those at ERDF

\section{Trench Entrance/Expansion:}

Assumptions:

1. There will be an Entrance/Expansion used for the backward ingress and forward egress from $12^{\text {th }}$ Street into the trench. This will allow the transport to quickly move off the street, and allow it to be aligned for ramp descent while off the street.

2. The Entrance/Expansion will flare out by $12^{\text {th }}$ street to allow easy access. This flare will be twice the turning radius of the transport at the street.

3. The Entrance/Expansion will neck down as it approaches the ramp.

4. The Entrance/Expansion will be constructed of graded native soil and gravel

5. The native soil is similar to that of the neighboring Trench 94 .

6. The cost of grading native soil and constructing a gravel road in that area will be the same cost per square foot as the ERDF access road. This is based of the natural contour and grades of that area, and the similarity of the construction.

\section{Ramp:}

Assumptions:

1. The access road will as short as possible. Assumed twice the length of the transport (304$452 \mathrm{ft}$ ) to allow maneuvering in and out on a level surface. Therefore, the ramp/trench entrance will be located $304-452 \mathrm{ft}$. south of $12^{\text {th }}$ Street.

2. The native soil is similar to that of the neighboring Trench 94 .

3. The ramp design and construction will be similar to that of the Trench 94 ramp.

4. The ramp grade and the slope of the side cuts will be the same as those of Trench 94 (1 $\mathrm{ft}$ of rise per $1.5 \mathrm{ft}$ of run). 


\section{RPP-7094 REV 0}

5. The trench floor will be at $36 \mathrm{ft}$ deep (16.5 ft of cover (just over the required 5 meters), 16.5 $\mathrm{ft}$ tall waste package, $3 \mathrm{ft}$ of exposed rail system.)

6. Length of the ramp will be $720-1800 \mathrm{ft}$ long, based on acceptable slope for the various transports being considered.

\section{Trench Alignment Vestibule:}

Assumptions:

1. There will be an Alignment Vestibule used to align the transport and trailer to the rail system. This will become a necessity as the future phase II modules are added.

2. The native soil is similar to that of the neighboring Trench 94 .

3. The melters will be placed on the trailers lengthwise. The larger LAW melters requiring $17.5 \mathrm{ft}$. of beam.

4. There will be a transition area between the ramp and the Alignment Vestibule. This transition will further ease transport alignment. The transition area will be the length of the trailer and consist of a $45^{\circ}$ transition into the Vestibule area.

5. The alignment vestibule will be $304-452 \mathrm{ft}$ long. (Based on two times the length of the transport).

6. The alignment vestibule will be $72 \mathrm{ft}$ wide. (Based on three times the length of the transport).

7. The alignment vestibule side cuts will be the same as those of Trench 94 ( $1 \mathrm{ft}$ of rise per $1.5 \mathrm{ft}$ of run).

7. The trench floor will be at $36 \mathrm{ft}$ deep ( $16.5 \mathrm{ft}$ of cover (just over the required 5 meters), $16.5 \mathrm{ft}$ tall waste package, $3 \mathrm{ft}$ of exposed rail system.)

\section{Rail System:}

Assumptions:

1. The native soil is similar to that of the neighboring Trench 94 .

2. The rail system size, footing design and construction will be similar to that of the Trench 94 rail system.

3. Differences in the rail system design from those Trench 94 rail system will not significantly impact cost, or schedule.

4. The rail grade will be level and employ winches similar to those used at the Vitrification facility to move the melters.

5. Each trench module will have an independent rail system. 
6. The LAW and HLW container can be commingled on a single rail system and loaded in order of arrival.

7. The melters will be placed on the rail system widthwise, with the LAW melters consuming $17.5 \mathrm{ft}$. of rail storage, and the HLW melters consuming $17.4 \mathrm{ft}$. of rail storage. (Based on the trailer carrying them lengthwise and loading them onto the rail system from the side of the trailer.)

8. The length of the rail system will facilitate $10 \mathrm{LAW}$ and $3 \mathrm{HLW}$ melters with $3 \mathrm{ft}$ spacing on the sides for surveillance. Additional $3 \mathrm{ft}$ spacing was assumed at the ends. The winch system is not accounted for in the length of the rail system. Therefore the total length of the rail system is $269.2 \mathrm{ft}$

\section{Rail trench cut:}

Assumptions:

1. The native soil is similar to that of the neighboring Trench 94 .

2. The rail system size, footing design and construction will be similar to that of the Trench 94 rail system.

3. The rail grade will be level.

4. The LAW and HLW container can be commingled on a single rail system and loaded in order of arrival.

5. The melters will be placed on the rail system widthwise. (Based on the trailer carrying them lengthwise and loading them onto the rail system from the side of the trailer.) The larger LAW melters require $26.6 \mathrm{ft}$. of beam.

6. An additional $6 \mathrm{ft}$ of flat ground on either side of the larger LAW melters to allow a level walkway for surveillance and an added buffer space for drainage. Therefore, the total width of the level section of the trench module is $38.6 \mathrm{ft}$.

7. There will be a berm, similar to that of the ERDF trench berms, surrounding the level section of the trench modules, with a removable end section for loading.

8. The berm will be $6 \mathrm{ft}$ wide and $2 \mathrm{ft}$ tall. The side slopes of the trench will begin immediately at the outside of the berm perimeter. Therefore the total width of the rail trench cut will be $50.6 \mathrm{ft}$

9. The length of the rail system will facilitate $10 \mathrm{LAW}$ and $3 \mathrm{HLW}$ melters with $3 \mathrm{ft}$ spacing for surveillance. Additional $3 \mathrm{ft}$ spacing was assumed at the ends. $20 \mathrm{ft}$ will be left at the far-end of the rail trench cut to allow for a pulley/winch system as needed. A $6 \mathrm{ft}$ wide walkway will be left inside the berm at near-end of the rail trench cut. Therefore the total length of the rail cut trench will be $307.2 \mathrm{ft}$. 


\section{RPP-7094 REV 0}

8. The rail trench cut will have side cuts similar to as those of Trench 94 (1 $\mathrm{ft}$ of rise per $1.5 \mathrm{ft}$ of run).

9. The trench floor will be at $36 \mathrm{ft}$ deep ( $16.5 \mathrm{ft}$ of cover [just over the required $5 \mathrm{~m}$ ], $16.5 \mathrm{ft}$ tall waste package, $3 \mathrm{ft}$ of exposed rail system).

10. The trench excavation will be $48 \mathrm{ft}$ deep ( $16.5 \mathrm{ft}$ of cover [just over the required $5 \mathrm{~m}$ ], $16.5 \mathrm{ft}$ tall waste package, $3 \mathrm{ft}$ of exposed rail system, $3 \mathrm{ft}$ of buried sleeper sections, and $9 \mathrm{ft}$ of double liner system).

\section{Rail trench cut double liner system:}

Assumptions:

1. The native soil is similar to that of the neighboring Trench 94 .

2. The rail system size, footing design and construction will be similar to that of the Trench 94 rail system.

3. The rail grade will be level.

4. The total width of the level section of the trench module is $38.6 \mathrm{ft}$.

5. There will be a berm, similar to that of the ERDF trench berms, surrounding the level section of the trench modules, with a removable end section for loading.

6. The berm will be $6 \mathrm{ft}$ wide and $2 \mathrm{ft}$ tall.

7. The side slopes of the trench will begin immediately at the outside of the berm perimeter. Therefore the total width of the rail trench cut will be $50.6 \mathrm{ft}$

8. The total length of the rail cut trench will be $307.2 \mathrm{ft}$

9. The Sideslope Liner Section will be similar to that of ERDF. It will be $7 \mathrm{ft}$ thick, consisting of six layers, listed top to bottom they are the:

- Operations Layer

- Primary Drainage Geocomposite

- Primary HDPE Geomembrane

- Secondary Drainage Geocomposite

- Secondary HDPE Geomembrane

- Compacted Admix

10. The Floor Liner Section will be similar to that of ERDF. It will be $9 \mathrm{ft}$ thick, consisting of 10 layers, listed top to bottom they are the:

- Operations Layer

- Geotextile Separator 
- Primary Drainage Gravel

- Geotextile Cushion $\left(1^{\text {st }}\right)$

- Primary HDPE Geomembrane

- Geotextile Cushion $\left(2^{\text {nd }}\right)$

- Secondary Drainage Gravel

- Geotextile Cushion (3rd)

- Secondary HDPE Geomembrane

- Compacted Admix

11. The Sideslope Liner Section will be at a 1:3 slope (rise:run).

12. The Floor Liner Section will be a level grade.

13. The trench floor will be $36 \mathrm{ft}$ deep ( $16.5 \mathrm{ft}$ of cover (just over the required $5 \mathrm{~m}$ ), $16.5 \mathrm{ft}$ tall waste package, $3 \mathrm{ft}$ of exposed rail system.)

14. The trench excavation will be $48 \mathrm{ft}$ deep ( $16.5 \mathrm{ft}$ of cover (just over the required $5 \mathrm{~m}$ ), $16.5 \mathrm{ft}$ tall waste package, $3 \mathrm{ft}$ of exposed rail system, $3 \mathrm{ft}$ of buried sleeper sections, and $9 \mathrm{ft}$ of double liner system.)

15. The Sideslope of the trench adjacent to the rail trench cut double liner system will not be covered with a HDPE covering until prior to backfill. Therefore, the cost will be assume to be covered during the closure operation after the completion of Phase II.

16. The rail trench cut double liner system will have a simple drainage collection system consisting of a sump gutter of either side of the trench, which drains into a surge sump. This surge pump will contain a level controlled pump, which pumps the leachate to an aboveground 10,000-gal holding tank for export to the effluent treatment facility. The holding tank will be housed in a secondary containment concrete enclosure able to hold $90 \%$ of the nominal capacity of the tank. The surge sump, pumps, pipes, controls, instrumentation, containment enclosure and holding tank will cost $\$ 100,000$ (Contractor construction cost only, no adders). 
RPP-7094 REV 0

\section{APPENDIX F}

ENVIRONMENTAL COMPLIANCE CHECKLIST 
RPP-7094 REV 0

This page intentionally left blank.

F-ii 


\section{ENVIRONMENTAL COMPLIANCE CHECKLIST}

\section{IDENTIFICATION OF ENVIRONMENTAL REQUIREMENTS}

The following table identifies environmental permits, approvals, and/or requirements applicable to the project. Any "Yes" answer in the applicability column will be further described in the narrative, which follows the table. Some "No" answers may require special explanation and will have narrative associated with them. In this case, the words "See Text" will be stated in the applicability column. A contact person is identified at the end of each evaluation to answer questions and/or provide additional information regarding the specific regulation in question.

The primary contact for identifying all environmental issues and defining strategy processes should be the facility environmental compliance officer (ECO). Since the vitrification project is undergoing a transition to a new contractor, only an environmental contact for the project has been designated (G. P. Chevrier, 373-3609) at the time of compilation of this checklist. FH Environmental Services has trained staff, who can assist until a suitable ECO is available within the project. Until a project ECO for melters disposal is formally designated, contact FH Project Planning (FA Ruck, 376-9876) or the low level burial ground (LLBG) ECO (D. G. Saueressig, 376-9739 for assistance.

Note also, that environmental requirements are often subject to change, particularly as a project proceeds toward final design. The checklist represents a "snapshot in time," which is usually based on preliminary planning data, usually that of the functional criteria. WMP Environmental Management Services strongly recommends that the criteria identified in this checklist should be reevaluated after the final design is complete, in order that the appropriate data is included in the final permits.

Since the Melter Disposal project interfaces with operations in the vitrification of both LAW and HLW, additional efforts may be needed for intercontractor interfacing. As the project becomes more defined, especially as it moves through the detailed design portion and into actual construction, further review for environmental issues is recommended. 
Vitrification Facility Melter Disposal Project -- Environmental Requirements/Permits/Approvals

\begin{tabular}{|c|c|c|c|c|c|}
\hline $\begin{array}{l}\text { ENVIRONMENT } \\
\text { MEDIA }\end{array}$ & $\begin{array}{l}\text { PERMIT, APPROVAL, } \\
\text { or REQUIREMENT }\end{array}$ & REGULATION(S) & $\begin{array}{l}\text { REGULATORY } \\
\text { AGENCY }\end{array}$ & RESTRICTION & $\begin{array}{l}\text { APPLY? } \\
\text { (Y or N) }\end{array}$ \\
\hline \multirow[t]{3}{*}{ NEPA } & $\begin{array}{l}\text { NEPA } \\
\text { Documentation }\end{array}$ & $\begin{array}{l}40 \text { CFR } 1500-1508 \\
10 \text { CFR } 1021 \\
\text { DOE Order } \\
451.1 \mathrm{~A} \\
\end{array}$ & DOE & $\begin{array}{l}\text { Title II Design } \\
\text { (Projects), } \\
\text { Procurement }\end{array}$ & Yes \\
\hline & $\begin{array}{l}\text { Price Anderson } \\
\text { Review }\end{array}$ & 10 CFR 830 & $\begin{array}{l}\text { DOE } \\
\text { FH Legal }\end{array}$ & $\begin{array}{l}\text { Operational } \\
\text { Readiness }\end{array}$ & Yes \\
\hline & $\begin{array}{l}\text { DOE Acquisition/ } \\
\text { ES\&H Management }\end{array}$ & 48 CFR 915 \& 970 & $\begin{array}{l}\text { DOE } \\
\text { FH/EP } \\
\end{array}$ & $\begin{array}{l}\text { Integrate Project } \\
\text { with ISMS } \\
\end{array}$ & Possible \\
\hline SEPA & $\begin{array}{l}\text { SEPA Documenta- } \\
\text { tion }\end{array}$ & WAC $197-11$ & Ecology & $\begin{array}{l}\text { License, } \\
\text { Permit }\end{array}$ & \\
\hline $\begin{array}{l}\text { External } \\
\text { Procurement }\end{array}$ & NEPA 216 Process & 10 CFR 1021.216 & $\begin{array}{l}\text { FH Procurement } \\
\text { DOE/RL }\end{array}$ & $\begin{array}{l}\text { Environmental } \\
\text { Critique before } \\
\text { external } \\
\text { contract is let. }\end{array}$ & \\
\hline CERCLA & $\begin{array}{l}\text { ARARs, } \\
\text { Model Toxics } \\
\text { Control Act } \\
\end{array}$ & $\begin{array}{l}40 \text { CFR } 300.400 \text {, } \\
\text { WAC } 173-340\end{array}$ & $\begin{array}{l}\text { EPA } \\
\text { Ecology }\end{array}$ & $\begin{array}{l}\text { Construction, } \\
\text { TPA cleanup }\end{array}$ & No \\
\hline \multirow[t]{3}{*}{ All Media } & $\begin{array}{l}\text { Cultural Resource } \\
\text { Review }\end{array}$ & $\begin{array}{l}10 \text { CFR } 1021, \\
36 \text { CFR } 63, \\
36 \text { CFR } 800, \\
43 \text { CFR } 7, \\
16 \text { USC } \\
461-470 \mathrm{aa}, \\
42 \text { USC } 1996, \\
42 \text { USC } 4321\end{array}$ & $\begin{array}{l}\text { DOE, } \\
\text { State Historic } \\
\text { Preservation } \\
\text { Office }\end{array}$ & $\begin{array}{l}\text { Archaeological, } \\
\text { Any surface } \\
\text { disturbance, } \\
\text { Building mods, } \\
\text { Historic Regis- } \\
\text { ter eligibility }\end{array}$ & \\
\hline & $\begin{array}{l}\text { Ecological } \\
\text { Compliance Review }\end{array}$ & $\begin{array}{l}10 \text { CFR } 1021, \\
50 \text { CFR } 17, \\
50 \text { CFR } 402.6, \\
16 \text { USC } 703-712 \text {, } \\
16 \text { USC } 1531, \\
\text { DOE Order } \\
5484.1, \\
\text { WAC } 232-12\end{array}$ & $\begin{array}{l}\text { USFWS, } \\
\text { Ecology }\end{array}$ & $\begin{array}{l}\text { Construction, } \\
\text { Excavation, } \\
\text { Habitat mods, } \\
\text { Protection of } \\
\text { threatened or } \\
\text { endangered } \\
\text { species }\end{array}$ & \\
\hline & $\begin{array}{l}\text { American Indian } \\
\text { Policies Review }\end{array}$ & $\begin{array}{l}42 \text { USC } 1966, \\
\text { DOE } 1230.2\end{array}$ & $\begin{array}{l}\text { DOE, } \\
\text { BIA }\end{array}$ & $\begin{array}{l}\text { Actions } \\
\text { impacting tribal } \\
\text { interests, } \\
\text { energy, cultural, } \\
\text { \& } \\
\text { environmental }\end{array}$ & \\
\hline
\end{tabular}




\begin{tabular}{|c|c|c|c|c|c|}
\hline \multirow[t]{7}{*}{ All Media (cont) } & $\begin{array}{l}\text { Floodplain/Wetland } \\
\text { Assessment }\end{array}$ & 10 CFR 1022 & DOE & $\begin{array}{l}\text { Any surface } \\
\text { disturbance }\end{array}$ & No \\
\hline & $\begin{array}{l}\text { Site Selection } \\
\text { Review }\end{array}$ & $\begin{array}{l}\text { HNF-PRO-551 } \\
\text { HNF-PRO-1998 }\end{array}$ & $\begin{array}{l}\text { DynCorp } \\
\text { Landlord }\end{array}$ & $\begin{array}{l}\text { Before Final } \\
\text { Design }\end{array}$ & No \\
\hline & Excavation Permit & 36 CFR 800 & DOE & Any excavation & 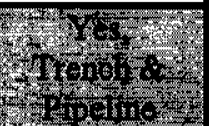 \\
\hline & $\begin{array}{l}\text { Pre-Operational } \\
\text { Rad } \\
\text { Monitoring of } \\
\text { Facility or Site }\end{array}$ & DOE Order 5400.1 & DOE & $\begin{array}{l}\text { Before Opera- } \\
\text { tion }\end{array}$ & \\
\hline & $\begin{array}{l}\text { General Radiation } \\
\text { Protection/Program } \\
\text { Standards } \\
\text { Radioactive Waste } \\
\text { Management }\end{array}$ & $\begin{array}{l}\text { DOE Order } 5400.1 \\
\text { DOE Order } 5400.5 \\
\text { DOE O } 435.1, \\
435.1-1 \\
\\
\text { DOE Order } 5820.2 \mathrm{~A} \\
\text { DOE Order } 435.1 \\
\text { Perf. Assessment }\end{array}$ & $\begin{array}{l}\text { DOE } \\
\text { DOE } \\
\text { DOE }\end{array}$ & $\begin{array}{l}\text { Construction } \\
\text { Waste storage/ } \\
\text { management } \\
\text { Before } \\
\text { Operation }\end{array}$ & (4) \\
\hline & $\begin{array}{l}\text { Facility Regulatory } \\
\text { File } \\
\text { Operational Records }\end{array}$ & $\begin{array}{l}\text { TOCFR } 830.120 \\
\text { DOE Order } 5700.6 \mathrm{C} \\
\text { WAC } 173-303\end{array}$ & $\begin{array}{l}\text { Ecology, } \\
\text { WDOH,EPA, } \\
\text { DOE-RL }\end{array}$ & Final Readiness & \\
\hline & $\begin{array}{l}\text { External Sample/ } \\
\text { Analysis }\end{array}$ & EPA-SW-846 & EPA & $\begin{array}{l}\text { Certified results } \\
\text { for compliance }\end{array}$ & $\begin{array}{c}\text { Only if } \\
\text { melters are } \\
\text { suspect } \\
\text { TRU }\end{array}$ \\
\hline \multirow[t]{6}{*}{$\begin{array}{l}\text { All Air } \\
\text { Emissions }\end{array}$} & $\begin{array}{l}\text { General Regulations } \\
\text { for Air Pollution }\end{array}$ & WAC $173-400$ & Ecology, & $\begin{array}{l}\text { Construction, } \\
\text { Operation }\end{array}$ & \\
\hline & $\begin{array}{l}\text { New Source Review, } \\
\text { Registration, } \\
\text { Temporary/ } \\
\text { Portable Air Units }\end{array}$ & $\begin{array}{l}\text { WAC } 173-400-110 \text {, } \\
\text { WAC } 173-400-114\end{array}$ & $\overline{\text { Ecology }}$ & $\begin{array}{l}\text { Construction, } \\
\text { Operation }\end{array}$ & $\frac{y_{3}^{4}}{\text { No }}$ \\
\hline & $\begin{array}{l}\text { Notice of } \\
\text { Construction } \\
\end{array}$ & $\begin{array}{l}\text { WAC 173-400, } \\
\text { WAC 246-247 } \\
\end{array}$ & $\begin{array}{l}\text { Ecology, } \\
\text { WDOH }\end{array}$ & Construction & 36) \\
\hline & $\begin{array}{l}\text { Air Operating } \\
\text { Permit } \\
\end{array}$ & WAC 173-401 & $\begin{array}{l}\text { EPA, Ecology, } \\
\text { WDOH } \\
\end{array}$ & Operation & 3rot \\
\hline & $\begin{array}{l}\text { Control Technology } \\
\text { BARCT, T-BACT, } \\
\text { ALARACT }\end{array}$ & $\begin{array}{l}\text { WAC 173-400-040, } \\
\text { WAC 173-460-030, } \\
\text { WAC 246-247-040, } \\
\text { WAC 246-247-130 }\end{array}$ & $\begin{array}{l}\text { Ecology, } \\
\text { WDOH }\end{array}$ & Final Design & 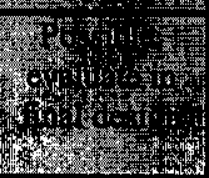 \\
\hline & $\begin{array}{l}\text { Modification to } \\
\text { Control Technology }\end{array}$ & WAC 173-400-114 & Ecology & $\begin{array}{l}\text { Construction, } \\
\text { Operation }\end{array}$ & No \\
\hline
\end{tabular}




\begin{tabular}{|c|c|c|c|c|c|}
\hline $\begin{array}{l}\frac{\text { Non- }}{\text { Radioactive }} \\
\text { Air Emissions }\end{array}$ & $\begin{array}{l}\text { Source } \\
\text { Review/NOC, } \\
\text { Source Registration } \\
\text { Prevention of } \\
\text { Significant } \\
\text { Deterioration } \\
\text { Toxic Air Pollutants, } \\
\text { Source Review } \\
\text { Dangerous/ } \\
\text { Hazardous waste, } \\
\text { RCRA air emissions }\end{array}$ & $\begin{array}{l}\text { WAC 173-400-110, } \\
\text { WAC 173-400-101 } \\
\text { WAC 173-400-141 } \\
\text { WAC 173-460-030, } \\
\text { WAC 173-460-040 } \\
\text { WAC 173-303 } \\
\text {-120(4)(e), -400(3), } \\
\text {-690, and -691, } \\
\text { 40 CFR 264/265 } \\
\text { Subpart CC }\end{array}$ & $\begin{array}{l}\text { Ecology } \\
\text { and } \\
\text { EPA }\end{array}$ & $\begin{array}{l}\text { Construction } \\
\text { Construction } \\
\text { Operations }\end{array}$ & 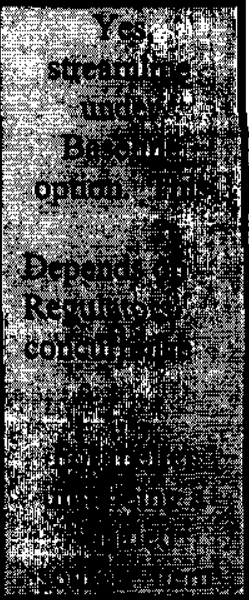 \\
\hline $\begin{array}{l}\text { Radioactive } \\
\text { Air Emissions }\end{array}$ & $\begin{array}{l}\text { Radiation Protection } \\
\text { - Air Emissions } \\
\text { Source Re- } \\
\text { view/NOC; } \\
\text { Control Technology, } \\
\text { BARCT/ALARACT } \\
\text { NESHAPs }\end{array}$ & $\begin{array}{l}\text { WAC-246-247 } \\
\begin{array}{l}40 \text { CFR 61, Subpart } \\
\text { H }\end{array}\end{array}$ & $\begin{array}{l}\text { WDOH } \\
\text { EPA }\end{array}$ & $\begin{array}{l}\text { Construction } \\
\text { Operation } \\
\text { with NOC } \\
\text { Review } \\
\text { Construction } \\
\text { Operation }\end{array}$ & 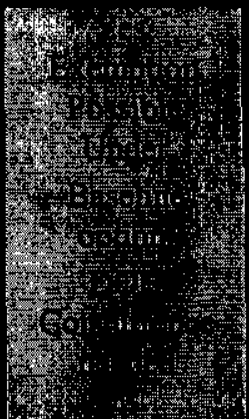 \\
\hline $\begin{array}{l}\text { Special } \\
\text { Substances }\end{array}$ & $\begin{array}{l}\text { Toxic Substances } \\
\text { PCBs } \\
\text { Pesticides/Herbicides } \\
\text { Waste Oils } \\
\text { Mixtures (Air and } \\
\text { Water Releases) }\end{array}$ & $\begin{array}{l}40 \text { CFR } 720, \\
40 \text { CFR } 761, \text { WAC } \\
173-303 \\
\text { WAC-228 to } 232 \\
\text { WAC } 173-303-040 \text {, } \\
-360,-515 \\
40 \text { CFR } 302,-355,- \\
372 \\
49 \text { CFR } 172, \\
\text { WAC } 173-303-145 \text {, } \\
-375\end{array}$ & $\begin{array}{l}\text { EPA } \\
\text { EPA, Ecology } \\
\text { State Dept of } \\
\text { Agriculture, } \\
\text { Ecology } \\
\text { Ecology }\end{array}$ & $\begin{array}{l}\text { Design, } \\
\text { Special } \\
\text { training, } \\
\text { Special } \\
\text { controls, } \\
\text { Notification } \\
\text { s }\end{array}$ & 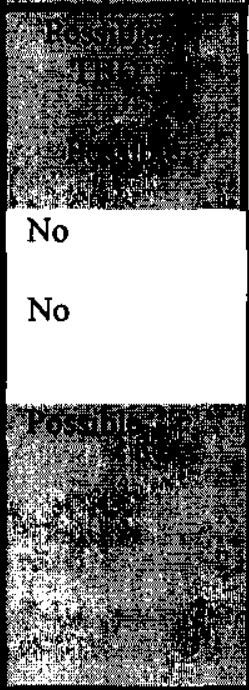 \\
\hline Asbestos & $\begin{array}{l}\text { Asbestos/Notice of } \\
\text { Intent }\end{array}$ & $\begin{array}{l}\text { BCCAA Reg. 1, } \\
\text { Article 8; } \\
40 \text { CFR 61, } \\
\text { Subpart M }\end{array}$ & BCCAA & $\begin{array}{l}\text { Special } \\
\text { training, } \\
\text { Notification } \\
\text { before } \\
\text { working } \\
\text { with } \\
\text { Asbestos }\end{array}$ & No \\
\hline $\begin{array}{l}\text { Outdoor or } \\
\text { Unconfined } \\
\text { Burning }\end{array}$ & (i) & $\begin{array}{l}\text { WAC 173-425; } \\
\text { BCAA Reg. 1, } \\
\text { Article } 5\end{array}$ & $\begin{array}{l}\text { Hanford Fire } \\
\text { Department, } \\
\text { BCAA }\end{array}$ & $\begin{array}{l}\text { Open } \\
\text { Burning }\end{array}$ & 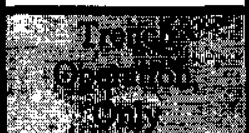 \\
\hline
\end{tabular}




\begin{tabular}{|c|c|c|c|c|c|}
\hline $\begin{array}{l}\text { CFCs, Ozone } \\
\text { Depleting } \\
\text { Substances }\end{array}$ & $\begin{array}{l}\text { Release Prevention; } \\
\text { Recovery/Recycle; } \\
\text { Certification, } \\
\text { Labeling }\end{array}$ & 40 CFR 82 & Ecology & $\begin{array}{l}\text { Reporting, } \\
\text { Training, } \\
\text { Operation }\end{array}$ & No \\
\hline \multirow[t]{2}{*}{$\begin{array}{l}\text { Soil Column } \\
\text { Waste Water } \\
\text { Disposal }\end{array}$} & $\begin{array}{l}\text { State Waste } \\
\text { Discharge } \\
\text { Permit/Water } \\
\text { Quality Standards } \\
\text { Engineering Report, } \\
\text { Plans \& Specs., and } \\
\text { O\&M Manual }\end{array}$ & WAC $173-240$ & $\begin{array}{l}\text { Ecology, } \\
\text { WDOH }\end{array}$ & $\begin{array}{l}\text { Monitoring } \\
\text { plan, } \\
\text { Operation } \\
\text { Approval } \\
\text { before } \\
\text { Construction }\end{array}$ & 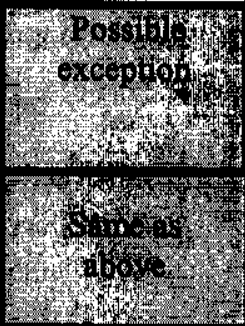 \\
\hline & $\begin{array}{l}\text { UIC Permit/ } \\
\text { Registration }\end{array}$ & WAC $173-218$ & Ecology & Operation & No \\
\hline \multirow[t]{5}{*}{$\begin{array}{l}\text { Domestic } \\
\text { Waste Water } \\
\text { Disposal }\end{array}$} & $\begin{array}{l}\text { Septic Systems } \\
<14,500 \text { gpd cap. } \\
\text { Design Approval }\end{array}$ & WAC 246-272 & WDOH & Construction & No \\
\hline & $\begin{array}{l}\text { Septic Systems } \\
\text { >14,500 gpd cap. } \\
\text { Design Approval }\end{array}$ & $\begin{array}{l}\text { WAC 173-216; } \\
\text { WAC 173-240 }\end{array}$ & Ecology & Construction & No \\
\hline & Pretreatment Permit & $\begin{array}{l}40 \text { CFR } 403 \text {; } \\
\text { City Ordinance }\end{array}$ & City of Richland & $\begin{array}{l}\text { Discharge to } \\
\text { city sewage } \\
\text { facility }\end{array}$ & No \\
\hline & $\begin{array}{l}\text { Operator } \\
\text { Certification }\end{array}$ & WAC $173-230$ & Ecology & Operation & No \\
\hline & Discharge Standards & WAC $173-221$ & Ecology & Discharge & No \\
\hline \multirow[t]{5}{*}{$\begin{array}{l}\text { Surface Waste } \\
\text { Water Disposal }\end{array}$} & NPDES Permit & 40 CFR 122 & EPA & Operation & No \\
\hline & $\begin{array}{l}\text { Certification of } \\
\text { NPDES Permit }\end{array}$ & 40 CFR 121 & Ecology & Operation & No \\
\hline & $\begin{array}{l}\text { Storm Water } \\
\text { Discharge Under } \\
\text { General Permit }\end{array}$ & $\begin{array}{l}57 \text { FR No. } 175 \\
\text { WAC 173-200 }\end{array}$ & EPA & $\begin{array}{l}\text { River } \\
\text { Construction }\end{array}$ & 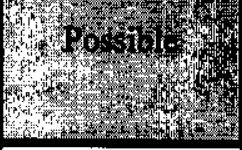 \\
\hline & $\begin{array}{l}\text { U.S. Dept of Army } \\
\text { Permit }\end{array}$ & 33 CFR 325 & USACE & $\begin{array}{l}\text { River } \\
\text { Construction }\end{array}$ & No \\
\hline & $\begin{array}{l}\text { Wild \& Scenic River } \\
\text { Section } 10 \text { Permit }\end{array}$ & $\begin{array}{l}33 \text { CFR } 320 \\
33 \text { CFR } 322\end{array}$ & USACE & $\begin{array}{l}\text { River } \\
\text { Construction }\end{array}$ & No \\
\hline
\end{tabular}




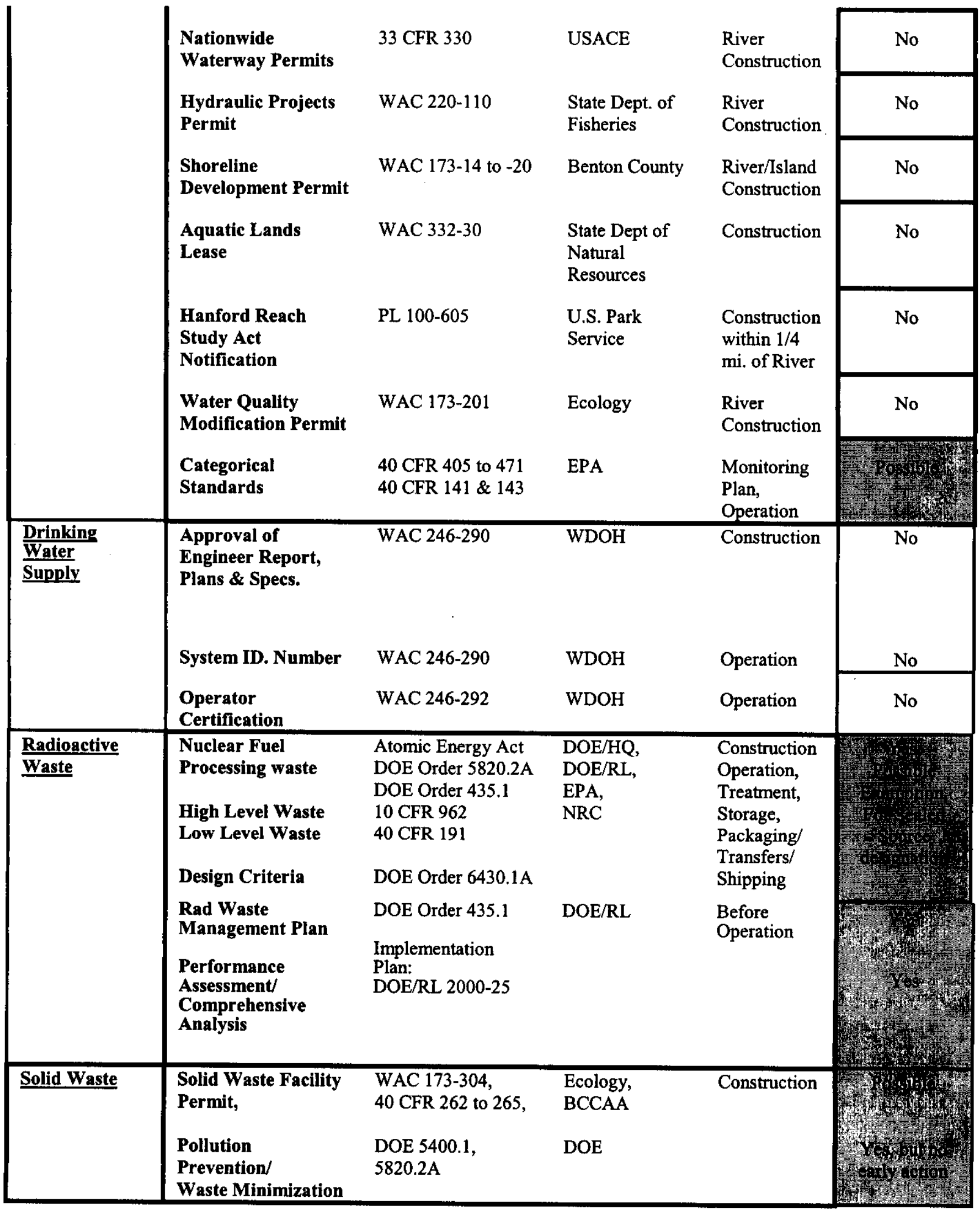


RPP-7094 REV 0

\begin{tabular}{|c|c|c|c|c|c|}
\hline \multirow[t]{5}{*}{$\begin{array}{l}\text { Dangerous } \\
\text { Waste }\end{array}$} & $\begin{array}{l}\text { RCRA/Dangerous } \\
\text { Waste Permit } \\
\text { (Part A and B) }\end{array}$ & $\begin{array}{l}\text { WAC } 173-303-800 \\
\text { thru-860; } \\
40 \text { CFR } 264 ; 40 \text { CFR } \\
265 ; \\
40 \text { CFR } 270\end{array}$ & Ecology & $\begin{array}{l}\text { Construction } \\
\text { of New } \\
\text { Facility, or } \\
\text { Expansion of } \\
\text { Exist Facility }\end{array}$ & 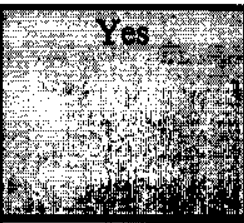 \\
\hline & Notice of Intent & WAC $173-303-281$ & $\begin{array}{l}\text { Ecology \& } \\
\text { Public }\end{array}$ & $\begin{array}{l}\text { Public } \\
\text { Reading } \\
\text { Room \& } \\
\text { Newspaper } \\
\end{array}$ & $\begin{array}{l}\text { Not needed if } \\
\text { LLBG Part B } \\
\text { finalized }\end{array}$ \\
\hline & $\begin{array}{l}\text { Construction or } \\
\text { expansion of surface } \\
\text { impoundment, } \\
\text { waste piles, or } \\
\text { landfill }\end{array}$ & WAC $173-303-335$ & Ecology & $\begin{array}{l}\text { Construction } \\
\text { quality } \\
\text { assurance } \\
\text { plans, } \\
\text { program, and } \\
\text { certification }\end{array}$ & 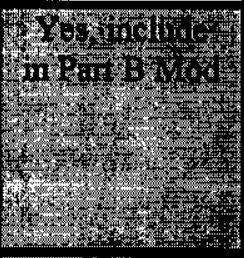 \\
\hline & $\begin{array}{l}\text { Satellite or }<90 \\
\text { Accumulation Areas }\end{array}$ & WAC $173-303-200$ & Ecology & $\begin{array}{l}\text { Any } \\
\text { hazardous } \\
\text { waste stream }\end{array}$ & - \\
\hline & $\begin{array}{l}\text { Nonstandard } \\
\text { Methods/RD\&D }\end{array}$ & $\begin{array}{l}\text { WAC } 173-303-500 \\
\text { to- } 607,-809 \&-830\end{array}$ & Ecology & $\begin{array}{l}\text { RD\&D } \\
\text { Permit, } \\
\text { Waivers }\end{array}$ & No \\
\hline USTs & Tank Permit & WAC $173-360$ & Ecology & Operation & No \\
\hline
\end{tabular}

These are the 'major' requirements; additional secondary requirements will be identified in the evaluations. 


\section{APPLICABILITY EVALUATIONS and COMMENTS}

\section{NEPA}

\section{National Environmental Policy Act (NEPA) Documentation - Title 10, CFR 1021}

NEPA requires federal agencies to examine ALL major activities for impacts on the environment. DOE does this by preparing an Environmental Impact statement (EIS) or an Environmental Assessment (EA). A NEPA compliance review is required for all proposed actions at Hanford to determine the appropriate level of environmental documentation. A categorical exclusion (CX) is issued by $R L$ if the proposed action clearly has no significant impact on the quality of the human environment. However, even those actions qualifying for a CX must still be documented. [NEPA does not allow larger projects to be cut up into a multitude of minor tasks; instead, the overall program must first be examined].

A NEPA Documentation Request Checklist (available on the Hanford Intranet via the FH Environmental Services home page) is completed and forwarded to FH Environmental Services to initiate the review process. NEPA documentation must be completed before starting Title II Design, or long lead procurements. NEPA/SEPA documentation requirements are in HNF-PRO452.

Note: All cultural and ecological surveys (see All Media section) must also be completed before NEPA documentation is submitted to RL.

\section{Price-Anderson Amendments Review - 10 CFR 820, 830, 835}

If a project or corrective action is being done in response to a deficiency or non-conformance under the Price-Anderson Amendments (PAA), then the closure authority, (defined in the PAA determination, and which is listed in the site Deficiency Tracking System database [DTS]), and the PHMC Legal Office must also review the project scope, the NEPA determination, and the permits - that will define closure of the deficiency and provide a basis for restart of the facility/process. Subpart 820 provides administrative guidelines. These should be incorporated in principle into the project planning. Subpart 830 provides application/implementation guidelines, including the use of a graded approach. Subpart 835 provides specific requirements for managing safety within a nuclear facility. A PAA guidance document for grading "significance" is available on the Hanford Intranet; see HNF-1950. See also HNF-MD-006 and HNF-MP-599.

\section{Department of Energy Acquisition Requirements (DEAR) - 48 CFR 915 \& 970 Integrated Safety Management System Interfaces}

All DOE Contractors must have an Environment, Safety and Health Management System in place and implemented to minimize environmental impacts of a project. To meet the DEAR clauses, the Project shall provide an interface between its own DEAR point of contact, the RL NEPA Compliance Office (NCO), and the project environmental compliance officer. 
The project ECO will ensure that environmental requirements are identified, (e.g. such as in this environmental requirements checklist). The FH Environmental Services organization will ensure that NEPA documentation has been accepted by the RL/NCO for those aspects of a project that are the direct responsibility of FH/WMP. Project management shall ensure that actions are integrated through the sitewide Integrated Safety management System (ISMS).

EVALUATION: The disposal of tank wastes has been discussed in several Environmental Impact Statements (EIS), primarily the Tank Waste Remediation Project (TWRS) EIS (DOE/EIS-0189, August 1996). A Record of Decision (ROD) accepting options from this document as a disposal strategy for tank wastes was issued Feb 26, 1997 (62FR-8693). Disposal of the melters is discussed as part of the generation/disposition of secondary solid wastes, resulting from the Hanford Clean-up Mission. These will be placed into a LLMW burial ground trench, which is discussed in the Hanford Solid Waste EIS (DOE/EIS-0286D), which is still in draft form; a summary and overview is available on the DOE/RL intranet EIS page. Trench design parameters are summarized in the SW EIS Technical Data Package, HNF-4755 (Draft C, Nov 1999). A ROD had not yet been issued at the time of developing this checklist.

As final design of the vitrification plant and internal processes proceed, additional detail will be available to improve the trench design. As the trench proceeds to final design, details supporting the various issues under NEPA/SEPA and operating permits will be determined. The baseline option reflects a very optimistic strategy.

The function of the Site Location Review has been captured by the SW EIS. The melters will be disposed of in the west end of burial ground 218-E-12B. There are numerous uncertainties, which will be determined only in the detailed design phase for the trench. Only a portion of the LLBG will be actually requested for a RCRA permit from Ecology. This portion, which includes the proposed melter trench, is designated elsewhere as the Mixed Wasted Disposal Unit (MWDU). Throughout this checklist, reference to LLBG issues usually implies only those issues applying to the MWDU. These will probably be evaluated on a case-by-case basis, using either a Categorical Exclusion or Environmental Assessment and Finding of No Significant Impact (FONSI) in that time period. No further NEPA analysis/documentation is required at the time of compiling this checklist.

No DEAR issues have been identified at this time; it is assumed that the final contract to construct and operate the vitrification facility will include these. If applicable, these may be defined during final design activity.

No Price-Anderson Amendments Act issues have been identified at this time. The melter disposals support commitments made in the Federal Facility and Consent Order (Tri-Party Agreement); failure to meet one of the interim milestones would carry the same significance of risk as if it were a PAAA violation.

A cultural resources review has been made of the several locations inside the 200 East Area. This review is regularly repeated by PNNL HCRL, and a new review letter issued for all site contractors. The ecological baseline review has also been made by WMNW for the 200 East Area, and will be repeated prior to final design and the approval to start construction of the trench. [Near-facility environmental monitoring data is published in PNNL-12088, Appendix A2, for the CY1998].

ACTION -- When design requirements are finalized, a letter will be requested from the RL NEPA Compliance Office, stating that all significant environmental impacts are satisfactorily documented and suitably mitigated under the EISs, and/or other supplemental documents. 


\section{SEPA}

\section{State of Washington Environmental Policy Act Documentation - WAC 197-11}

SEPA is the State equivalent of NEPA, requiring evaluation of the project's environmental impacts before it can be approved. A SEPA checklist is completed when required by Ecology; (typically, only if some state permit, other than an air permit is needed). An EIS or EA developed under NEPA may substitute (at the option of Ecology) for the SEPA checklist. The DOE/RL NEPA Compliance Officer will forward copies of the NEPA documentation and/or SEPA Checklist to the State. Ecology will determine if a State EIS/checklist is required or will issue a determination of non-significance.

EVALUATION: Since Ecology was an active participant in the developing the EISs, SEPA concurrence should be streamlined. A notification letter to Ecology, identifying adoption of the NEPA documentation for the melter disposal (including waste designation, trench construction and operation, melter transport and disposal in the 218-E-12B burial ground) and requesting their concurrence in lieu of a SEPA checklist is suggested. This documentation will be referenced in the Class 3 modification to the LLBG Part B permit.

\section{NEPA 216 Process/Environmental Critique - 10 CFR 1021.216}

For those procurement actions with potential environmental liabilities, which are not specifically included in the NEPA documentation, the environmental impacts must be evaluated prior to placing service contracts with external suppliers. All bidder proposals must be evaluated for past compliance history, effectiveness of proposed mitigation, and the potential bidder responsibilities for environmental compliance. The NEPA compliance guidelines in 10 CFR 1021.216 must be followed and the results issued in an Environmental Critique. Evaluation results must also be approved by the DOE/RL NEPA Compliance Office prior to final contract. These evaluations become part of the formal procurement documentation and may be published as part of the public record.

EVALUATION: No NEPA 216 items have been identified at the time of developing this checklist.

\section{CERCLA}

\section{Comprehensive Environmental Response, Compensation and Liability Act: Applicable or Relevant and Appropriate Requirements (ARARs)- 40 CFR 300.400}

The Hanford Site has been included on the National Priorities List, under CERCLA section 300. No Federal, State, or local permits are required for onsite response actions covered by CERCLA, Sections $104,106,120,121,121$, or 122 . This exception is allowed because onsite response actions must comply with the substantive parts of ARARs. On the Hanford Site, an activity is recognized as a CERCLA activity if the unit is identified as a CERCLA operable unit in the 
Tri-Party Agreement (TPA), or the activity is documented and performed in accordance with the CERCLA process. CERCLA remedial actions must comply with the substantive requirements of ARARs both during the remedial action and upon completion of the remedial action.

The Hanford Federal Facility Agreement and Consent Order of 1989 (and all amendments) recognizes that some CERCLA releases may be covered by the Washington State Model Toxics Control Act (MTCA). These will be included as ARARs, where appropriate; see HNF-PRO-454 and HNF-PRO-455. Additionally, removal actions (commonly called interim actions or expedited response actions) must comply with ARARs depending upon the urgency and scope of the circumstances and the removal action. The substantive portions of ARARs are generally required unless the removal is an emergency situation that does not allow for a planning phase to identify ARARs.

\section{Washington State Model Toxics Control Act (MTCA), WAC 173-340}

Ecology will use the Model Toxics Control Act residual standards (analogous to CERCLA standards) to make decisions regarding the "contained-in policy" for miscellaneous media. If environmental media are contaminated with a listed waste, AND meet the definition of debris (WAC 173-303-040 and 40 CFR 268.2), AND the solids exceed $60 \mathrm{~mm}$--then alternative treatment standards of 40 CFR 268.45 may be applicable, instead.

(See MTCA discussion in Special Substances section, following).

EVALUATION: Only RCRA-controlled issues will be involved in the melter disposal. The melters may possibly be designated as "debris, but the intent of the baseline option is to seek concurrence that the melters are "sealed units," and therefore no possible escape of contamination is possible.

No CERCLA or MTCA-controlled issues have been identified at the time of developing this checklist.

\section{ALL MEDIA}

\section{Cultural Resources Review (CRR) - 36 CFR 800}

A cultural review (a.k.a., Section 106 Review) shall be performed for any project involving demolition, modification, or deactivation of a potentially historic facility or structure. The cultural resource review must be made before initiating any external surface-disturbing activities onsite, or if any modifications are planned for any facility with the potential for inclusion on the National Register of Historic Places. The review will normally be made by PNNL/Hanford Cultural Resources Laboratory (HCRL); the request to perform this review is Site Forms \#RL665. Reference material may be reviewed at the URL - http://www.achp.gov

This CRR assessment will locate and identify any artifacts (e.g., control panels, signs, scale models, etc.), which may have interpretive or educational value as exhibits within local, state, or national museums. This notice needs to be paced at or near the top of the checklist, before anything is removed from the building. To initiate this process, the CRR needs to be filed with HCRL. If the CRR does indicate the potential for impacting historic issues, the results must be approved buy the State Historic Preservation Office (SHPO). This process may add an 
additional 30 days to the approvals schedule. As a rule of thumb, projects should request the cultural review at least 45 days prior to scheduling any implementation, to avoid schedule impacts.

EVALUATION: No action needed at this time. There are no cultural issues currently identified by PNNL/HCRL for locations inside the 200 East Area. A CRR letter is usually issued annually by PNNL. This condition will be verified by the design team after the $90 \%$ design is complete for the trench.

\section{Ecological Compliance Review - 10 CFR 1021; 50 CFR 402.6; DOE Order 5484.1}

A site survey should be performed to identify: any plant or animal species protected under the Endangered Species Act; candidates for such protection; species listed as threatened, endangered, candidate, sensitive, or monitored by the state of Washington; and species protected under the Migratory Bird Treaty Act. Also assessed is whether the planned activities have the potential to disturb any priority habitats and/or species identified in the survey. The review is normally performed by WMNW Environmental Monitoring staff. The request form to perform this review is Site Forms \#RL-665. This review also fulfills the NEPA ecological/biological review requirement.

\section{American Indian Tribal Government Agreements - DOE 1230.2}

American Indian Tribal Governments have a special and unique legal relationship with the U.S. Federal Government and its agencies. These are defined in numerous treaties, statues, historical precedents, and the U.S. Constitution. In addition, the State of Washington has agreements respecting current and future use of the lands surrounding the Hanford Site. All actions on the Hanford Site, which may impact these agreements, must be approved by the DOE-RL office for Native American interests. The Cultural Resource Review will be the mechanism for identifying any such potential impacts.

EVALUATION: No action needed at this time. Activity within the 200-East Area has been identified in previous programmatic/project planning documents as having no new ecological impacts (e.g., no plant or animal species protected under the Endangered Species Act; candidates for such protection; species listed as threatened, endangered, candidate, sensitive, or monitored by the state of Washington; and species protected under the Migratory Bird Treaty Act). The planned activities are inside an already-disturbed area, as far as habitat of species is concerned.

No Native American Tribal issues have been identified at the time of preparation of this checklist.

No aspects of protecting special status plant or animal species -- taking, possession, transportation, sale, purchase/barter, export, import, etc, are part of the scope of the melter disposal activity. Some removal/ remediation tasks, corrective actions, decontamination/decommissioning (D\&D) activities, and minor permanent construction activity may become included in a later phase of the project. Provision for these will be included in the facility closure plan, but the details will be very general. As such these are outside the present scope of this checklist.

When modifications covering the design/construction of the melter disposal trench are developed for the LLBG Part B permit (scheduled -- effective Dec 2002) the Tribes will be given opportunity to provide comments on the final trench design and other aspects of the Part B submittals. 


\section{RPP-7094 REV 0}

\section{Floodplain/Wetland Assessment - 10 CFR 1022}

A Floodplain/Wetland Assessment applies to all proposed floodplain/wetlands actions. A proposed action shall be designed to minimize potential harm to or within a floodplain. The assessment should be performed in conjunction with the NEPA evaluation process.

EVALUATION: Not applicable. There were no aspects of the melter disposal action, which will impact floodplain or wetlands.

\section{Site Selection/Location Review - HNF-PRO-551, Section 3.3.2.3, HNF-PRO-1998}

Any new facility must receive a landlord site location review, coordinated by Dyncorp/Site and Land Use Planning organization. This review is a Hanford best management practice. It offers an opportunity during the early planning stages to identify unusual or uncertain compliance, safety or operations issues. It integrates landlord issues/use options in a similar manner as the alternatives review under NEPA (Environmental Impact Statement, or Environmental Assessment); However, it does not substitute for NEPA compliance.

EVALUATION: The sites of the HLW and LAW vitrification facilities have been determined for the baseline option; see RPP-6270. The Melter Disposal Trench will be constructed inside the 218-E-12B burial ground. Since NEPA documentation has been prepared for these items, no further Site Selection Review is needed.

\section{Excavation Permit - 36 CFR 800}

An excavation permit is required before initiating any potential surface-disturbing onsite activities. The request form to obtain this permit is located on the HLAN, under Site Forms, [A-7400-373, "Hanford Excavation Permit"]. The facility Environmental Compliance Officer (ECO) may review and approve excavation permits prior to excavation begins, to ensure that all environmental, cultural and ecological resource reviews have been completed.

EVALUATION: An excavation permit will be obtained after the final design for the disposal trench is completed, but before any on-location digging is done. Some excavation of road-bed materials may be needed to upgrade the transport route and withstand the increased weight of the loaded transporter. This process is part of the site landlord/maintenance and has been evaluated as having no environmental compliance impacts.

The preliminary trench depth (per SW EIS Data Package) would be $70 \mathrm{ft}(21 \mathrm{~m})$. Since the depth to groundwater in the 200 East Area is 200 feet $(\sim 60 \mathrm{~m})$ or more, there should be no groundwater impacts due to the digging of the disposal trench.

[Excavation for construction of the vitrification facilities will also require a permit. This permit will be part of the vitrification contractor responsibility.] 


\section{Preoperational Monitoring of Facilities, Sites, and Operations - DOE Order 5400.1 Mitigation Action Plan}

A preoperational environmental study shall be conducted before startup of a site, facility, or process that has the potential for significant adverse environmental impact. This study should begin not less than 1 year (preferably 1 years) before startup, so seasonal changes can be evaluated. This study precedes the conceptual design report and can include data acquired in the site selection process, excavation permit process, and NEPA/SEPA process. For more information see the environmental compliance procedures, HNF-PRO-453, HNF-PRO-456 \& HNF-PRO-457. (Waste Management Northwest coordinates this action for PHMC.)

As a result of the NEPA evaluation, or other regulatory-driven agreements, a Mitigation Action Plan may be required. These plans are used to enhance equivalent offsetting impacts (e.g., for threatened or endangered species), when a project can not be made fully compliant with needs revealed by the Cultural/Ecological Resources survey, or the Preoperational Baseline.

EVALUATION: The pre-operational (baseline/background) environmental study will be included in the construction/operating contract responsibilities of the new vitrification contractor. The pre-operational study of the disposal trench area will be coordinated through the WMP SWD. WMNW is the recommended operational organization for these tasks. The site already conducts annual near-facility monitoring, which is reported in the annual Environmental Report; (the latest data is in document PNNL-12088, Appendix A2 for CY1998).

Mitigation/restoration of the land to be used for the vitrification facilities and for the disposal trench will be determined in the final phase of the project (D\&D of the plant and closure of the trench). The Comprehensive LandUse Plan (DOE/EIS-0222D-R) contains some strategic goals, but leaves details to be determined later.

\section{General Public/Environmental Protection - DOE Order 5400.1, DOE Order 435.1 Radiation Protection Standards - DOE Order 5400.5}

DOE Order 5400.1 requires that all DOE Sites prepare an environmental monitoring plan, and requires all Hanford facilities and projects to incorporate an overall protection program for environment, public and workers.

DOE Order 5400.5 establishes standards and requirements that must be followed to protect members of the public and environment against undue risk from radiation. DOE/RL 91-50, Hanford Site Environmental Monitoring Plan, includes DOE/EH-0173T, Environmental Regulatory Guide for Radiological Effluent Monitoring and Environmental Surveillance, which provides specific guidance regarding environmental monitoring activities.

DOE Order 435.1 (which supersedes 5400.1, and becomes effective FY 2001) requires that every waste generating facility also have a waste management plan and identify a disposal path for all wastes.

[For High-Level Waste requirements, see later section.] 


\section{Facility Regulatory File/Operational Records - 10CFR 830.120, DOE 5700.6C, WAC 173- 303}

Document and records control processes shall be established and implemented by $\mathrm{FH}$ and its subcontractors to satisfy the requirements of this Section in accordance with 10 CFR $830.120(\mathrm{c})(1)(\mathrm{iv})$, "Documents and Records," and DOE Order 5700.6C (9)(b)(1)(d), "Criterion 4--Documents and Records."

Every facility that treats, stores, disposes (TSD) or otherwise manages regulated wastes -- must maintain a file to control records, which demonstrate compliance with the applicable requirements in this checklist. The facility must be able to supply operational data as input to several required reports (see HNF-PRO-453, table 2). This is also a best management practice, under the PHMC organization, in which compliance can be demonstrated most easily to external inspectors, assessors and auditors. See RCRA section, following, for TSD facility permit.

Documents that define processes, specify requirements, or establish design shall be identified, prepared, reviewed, approved, issued, used, and revised when necessary. Controlled documents, including revisions, shall be reviewed for adequacy, completeness, and correctness before approval and release.

Major document changes shall be reviewed and approved by the same organizations that performed the original review and approval, unless other organizations are specifically designated. Minor document changes, such as inconsequential editorial corrections, may not require the same review and approval as the original documents.

Records shall be specified, identified, prepared, reviewed, approved, and maintained. Sufficient records shall be generated to accurately reflect completed work and demonstrate compliance with applicable requirements.

Maintenance of records shall include provisions for correction, replacement, retention, protection, preservation, traceability, accountability, and irretrievability.

Records shall be dispositioned following General Records Schedule published by the National Archives and Records Administration (NARA) or DOE-unique schedules. Copies of superseded or canceled controlled documents shall be identified and kept as records for their specified retention period.

EVALUATION: The strategic planning document will identify the contents of the waste management plan and the path-forward for disposal. The baseline option identified in the project scope section essentially identifies all details and assumptions known at the time this checklist was developed.

Facility management roles and responsibilities for the melters, designated as solid wastes, are identified in: HNFPRO-5121, Waste Designation and Land Disposal Restrictions; HNF-PRO-5122, Dangerous Waste Generator Activities, HNF-PRO-5123, Mixed Waste; HNF-PRO-5125, Radioactive Waste; and HNF-PRO-5127, Treatment, Storage and/or Disposal Units.

A sitewide strategy for radioactive waste management has been developed; see HNF-IP-??? Tier-down implementing plans will be developed using existing database information for each Hanford facility, including the LLBG. Suitable data will be extracted from the final anproved desiens of both the vitrification facilitv and 
the $218-\mathrm{E}-12 \mathrm{~B}$ burial ground to meet this requirement.

A facility operations plan will need to be developed to incorporate the requirements of the melter disposal trench within the 218-E-12B LLBG. This will provide input to the Performance Assessment and Comprehensive Analysis documents. The operations plan will also assist/define revisions to the RCRA Part B permit for the LLBG. After the trench design is complete, a facility effluent monitoring determination will be made; see the air emissions (next) section.

Until an operations plan is defined, the melter disposal assumptions in this checklist will define the scope of the activities.

\section{ALL AIR EMISSIONS}

\section{Notice of Construction (NOC) - WAC 173-400, WAC 246-247}

The NOC must include a description of the new construction or modification activities. The NOC must also include estimates of actual and potential emissions (both hazardous and radioactive contaminants) and an assessment of the applicable best control technology to be used. The need for a NOC also triggers the need for generating and maintaining specific records by the facility. Ecology, Health (or other authority) must review plans, specifications, associated information, and approve the NOC for the new or modified source. Construction must begin within 18 months after this approval.

\section{Portable/Temporary Radioactive Air Emissions Units (PTRAEUs) - WAC 246-247}

Transportable and temporary air handler units will be allowed to operate for periods of up to 1-2 years under specific conditions. The operation should be no worse than if the unit was a fixed-in-place emissions release point, and notification must meet the Wash Dept of Health guidelines. Emissions must be monitored, and reported at least semiannually; see HNF-PRO-450.

EVALUATION: The baseline option (see project scope section) should not require filing a notice of construction with either the Department of Health or the Department of Ecology. The baseline assumes that the melters can be designated as a contact-handled, sealed source -- meeting the LDRs; [see assumptions \#5, 6, $8,15,18$, and 19 for LAW melters].

A Facility Emissions Monitoring determination will be made in support of the application for determination by both Ecology and DOH. No air emissions are anticipated, once the melter unit is released for transport to the disposal trench. A determination of the proposed status/designation of the melters should be sought with both DOH and Ecology as soon as the design boundary is finalized. The LAW melters will be considered non-TRU.

The baseline option assumes that the HLW melters can be sufficiently processed within the vitrification facility in order to meet essentially these same, or similar criteria. Failed HLW melters may need to be individually characterized if the melter contains more than a threshold amount (e.g., less than 13 inches) of vitrified material inside. HLW melters with large amounts of glass might need to be designated as TRU waste, and would then be required to be shipped to the WIPP, in New Mexico; [see assumption \# 52]. That event is unlikely and is outside the scope of this checklist.

No Portable/Temporary Air Release Units will be used in the melter disposal activities. 


\section{Air Operating Permit (AOP) - WAC 173-401}

WAC 173-401 established a comprehensive Washington State AOP Program, meeting the requirements of Title $\mathrm{V}$ of the Federal Clean Air Act. A single sitewide permit is required for the Hanford facilities. This permit covers both radioactive and nonradioactive airborne emissions from all emission units that meet significance criteria defined by the Act. [An emissions release source is considered significant if it has the potential to contribute more than one percent of the total Hanford facility's exposure to the general public.]

The airborne emissions include, but are not limited to, criteria pollutants and hazardous air pollutants (including radionuclides). In this regulation, Ecology also has established thresholds for regulated pollutants below which emissions are considered insignificant (Insignificant Emission Units/IEUs) for the purposes of the AOP program. IEU items/activities must comply with general standards, but are exempt from the administrative requirements of the permit.

The AOP identifies emission limits and conditions of operation for sources on the Hanford Site. If a new NOC is required (see following section), and an emission unit becomes operational after the permit is issued by the state, a permit revision may be required prior to commencing operation. This application for modification is prepared in accordance with WAC 173-401-725

EVALUATION: At the time of development of this checklist the Hanford AOP had not been approved by the state. The vitrification facility will be included as part of the overall Hanford Air Operating Permit. The LLBG will also be included, although it has been determined that the burial grounds (especially, the MWDU) does not need a separate environmental monitoring plan.

The Near-Facility Monitoring report (see All Media section) would incorporate sufficient coverage to show compliance for the burial grounds as non-point sources. Under the baseline option, the PHMC assumes that no airborne releases will occur, and hence AOP inclusion is not needed for melter transport and trench disposal.

Under various secondary options, a greater degree of preliminary design and evaluations would be required before determining the extent of permitting required.

\section{NONRADIOACTIVE AIR EMISSIONS}

\section{New Source Review Applicability - WAC 173-400-110}

Any new activity, project, process, or equipment that will involve potential emissions of contamination to the air is subject to a pre-construction review and approval by the state. Also, if the activity involves a physical or operational change at an existing source of air emissions, and the change will result in ANY increase in the rate of contaminant emissions to the ambient air from the existing source, this may be considered a modification.

To determine whether a change constitutes a modification, emissions that will result after the change are compared to a baseline which is normally the annual rate of emissions observed from the facility, structure, or process during the previous 2 years of operations. When determining whether increased emissions would occur, additional abatement by any planned emissions control equipment may not be factored in. 
The impact may be related to such factors as increased flow rate or concentration of effluent, upstream heating or mixing of source material, or increased exposure to outside air. Use of best available control technology is often required.

The NOC must include a description of the new construction or modification activities, including details of any effects the construction activity (or the new/changed operations) would have regarding containment or release of radionuclide air emissions. The NOC must also include estimates of actual and potential emissions and an assessment of T-BACT. [Concurrence with the information presented in the nonradioactive NOC is usually expedited through a regular interface meeting with the Dept of Ecology, facilitated by FH/Environmental Services].

Notice of Construction/New Source Review - WAC 173-400-110

Modifications to Emission Control Technology - WAC 173-400-114

Before a new or modified source of regulated air emissions is constructed, installed, or established, Ecology (or other authority) must review plans, specifications, associated information, and approve the Notice of Construction (NOC) for the new or modified source.

The NOC is a written application to permit construction of a new source or modification of an existing source; see the Radioactive Air Emissions section, below. The application describes the proposed design, assesses potential impacts to the public and environment, and provides an assessment of best available control technology (BACT). An NOC for nonradioactive air emissions may be required, for sources subject to WAC 173-400 and 173-460 registration. In some cases a single, a combined NOC may be submitted for approval by the appropriate State or local agency.

The New Source Review will be conducted by Ecology on information submitted in the NOC. Particular emphasis will be made on compliance with applicable state and federal limitations, control technology, potential for impacts in a non-attainment area (such as winter inversions at Hanford), ozone, etc. The new source must meet special pollutant requirements as well as visibility requirements. Final determination will be made in a regulatory order within 30 days.

EVALUATION: The baseline option assumes that the NSR and NOC will not be required, as discussed previously. A letter of concurrence by Ecology should be sought as soon as possible confirming this, and incorporated in the strategic planning document.

If other considerations required that the melters be transported to the trench before being grouted, then the need for a NSR and NOC become highly probable. This would lead to an extensive permitting effort and potential delays due to reviews by numerous regulatory and oversight organizations.

Secondary options would require additional discussion of scope and requirement details, and greater degree of detail and estimates of the potential to emit for evaluation by Ecology.

[Note: The need for the NOC also triggers the need for generating and maintaining extensive specific records by the facility; see 40 CFR 61.95 and HNF-PRO-2595. Alternatives for excluding these exist and may be negotiated with Ecology for the baseline option.]

The FH/Environmental Services organization hosts a regular interface meeting with Ecology for the purpose of understanding and expediting approvals of NOCs and other compliance issues. A presentation for information will be made to Ecology at one of these meetings as soon as the supporting issues are defined for the melters, the transportation and the trench operation. 


\section{Prevention of Significant Deterioration (PSD) - WAC 173-400-141}

Any increased emission of criteria pollutants from a new or modified source may trigger a significant modification as defined by WAC 173-400-030 Potential annual amounts of expected increases must be considered. Pre-construction approval may be required by Ecology; see HNF-PRO-2595. The "criteria pollutants" include:

\begin{tabular}{||l|l||}
\hline$\bullet$ Carbon monoxide & - Lead \\
- Nitrogen oxides & - Fluorides \\
& - Sulfuric acid mist \\
- Sulfur dioxides & - Total reduced sulfur compounds $\left(\& \mathrm{H}_{2} \mathrm{~S}\right)$. \\
$\begin{array}{l}\text { - (volatile) organic compounds } \\
\text { WAC 173-400-030) }\end{array}$ & $\begin{array}{l}\text { Municipal waste combustor - acidic gases, } \\
\text { metals, or organics }\end{array}$ \\
\hline
\end{tabular}

If a Notice of Construction is required, the potential annual emissions of the criteria pollutants must be estimated and included. (See NOC Section, previously.)

\section{New Sources of Toxic Air Pollutants (TAPs) Requirements - WAC 173-460-030}

Activities that are considered modifications or new construction must be assessed for possible TAPs permitting. The TAPs evaluation (similar to the New Source Review, see prior section) will include potential and/or measurable emissions and a process description. TAPs may include airborne: Carcinogens, Asphyxiants, Mining Wastes, Petroleum Extraction Wastes, Major Manufacturing Wastes, Industrial and Dry Cleaning Solvents, Hospital Wastes (both inert and pathogenic), Spray Coating Wastes, Abrasive Demolition Wastes, and Chemical Process Releases. Criteria for the PSD may also apply to TAPs. The TAPs evaluation will identify all major contributions and associated threshold action limits, along with required controls. Some key requirements are:

- Does the proposed activity meet the definition of a new source for TAPs?

- Does the source fall into a category listed in WAC 173-460?

- Would the source emit either class A or class B TAPs?

- If above items are "yes" then -- Is the source exempt under WAC 173-460-30/40?

In addition:

- Best Available Control Technology is required to be utilized on new sources, and

- Reasonably Avail able Control Technology is required for projects when TAPs decrease or remain stable.

EVALUATION: Does not apply. Under the baseline option, the melters and contained waste are a single unit/sealed source, which has no potential for TAPs or criteria pollutants to be emitted. This assumption must be verified by discussions with the external regulators before it is final.

In secondary options, there may be potential for TAPs, which would need to be determined by sample/analysis of the waste-form at the time of declaring the melter as "waste." Process knowledge from earlier operations (using the same feed source) could be used to show contaminants are less than regulatory concern. 


\section{RADIOACTIVE AIR EMISSIONS}

\section{Radiation Protection - Air Emissions - WAC 246-247 Source Review/Notice of Construction - WAC 246-247-060}

The Washington State Dept of Health (DOH) is the regulatory agency for all radioactive air emissions. The $\mathrm{DOH}$ will make a case-by-case determination regarding the need to register any new or modified source of radioactive air emissions requiring an NOC. If an NOC is required (see WAC 246-247), the same data may be combined for both DOH and Ecology.

Note: A sealed source that has no possible mechanism to emit radioactive air contamination (per the baseline option assumptions) would be exempted from the requirements, although notification to $\mathrm{DOH}$ is still required.

Any new activity, process, or equipment that will involve potential emissions of radionuclides to the air is subject to a pre-construction review and approval by the DOH. If the activity involves a physical or operational change at an existing source of radionuclide air emissions, and the change will result in ANY increase in the rate of emissions of radionuclides to the ambient air from the existing source, review and approval by the DOH is required. Emissions resulting after the changes are compared to a baseline that is normally the annual rate of emissions observed from the facility, structure, or operation during the prior two years of operations. Other options for definition of the baseline exist and may be negotiated with DOH; see HNF-PRO-450.

The increase may be related to such factors as increased flow rate or concentration of effluent, upstream heating or mixing of source material, or increased exposure to outside air. When determining whether increased emissions would occur, additional abatement by any planned emissions control equipment may not be factored in.

An NOC application must be filed to obtain prior DOH approval of the new or modified activity; see NOC section, above. The NOC must also include estimates of actual and potential emissions and an assessment of BARCT or ALARACT as defined in the WAC 246-247. Any new major source of radioactive air emissions or major modification to a source must employ Best Available Radioactive Control Technology, per WAC 246-247-030, and the Hanford Site Radioactive Control Manual (HNF-5173). Where possible, this must also meet ALARA standards; see HNF-PRO-450.

The DOH currently makes a determination whether the air source needs a separate registration, based on data from the NOC. (After June 1998, this information will be included in the Hanford Air Operating permit.)

EVALUATION: Not required under baseline option. The Wash Dept of Health (DOH) must concur that the melter unit containing waste will be considered a "sealed source." This designation must be agreed on, by DOH.

Under the secondary options, a greater degree of detail must be determined, and the designs (preliminary and final) reviewed by $\mathrm{DOH}$. After the strategic planning document is finalized, an interface meeting to present the final strategy \& design definition should be established at the earliest convenient time. 


\section{National Emission Standards for Hazardous Air Pollutants (NESHAPs) - 40 CFR 61, Subpart H}

Any new stationary source of radionuclide emissions is subject to a preconstruction review and approval by the EPA, Region 10. Also, any new physical or operational activity that will provide any increase in potential emissions of radionuclides is defined as a modification and may require approval. Approval is obtained by submitting an DApplication for approval to construct or modify, $\square$ as required in 40 CFR 61.07. Additional operational records are required by NESHAPs designation; see 40 CFR 61.14(f).

EVALUATION: This requirement should not apply to the melter package being transported; however, the disposal trench may need to be evaluated and a facility emissions monitoring plan developed which is compliant to DOE Order 435.1 as well as NESHAP. Because of the grouting planned for the melter unit, the NESHAP potential contributions should be minimal (well below threshold of concern).

This issue will need to be reevaluated when final design is complete. Applicable items will be included in the closure plan section of the Part B modification and final status of the disposal trench.

NOTE: If one or more melters require transport from the vitrification facility to the trench before the grouting process is complete, a "potential to emit" estimate must be made. Special case permitting would probably be required in this event. The vitrification facility would have a facility effluent monitoring plan (FEMP), which would cover all processing of the melter unit during preparation to transport. The disposal trench would have its own, separate FEMP determination made. All emissions points that require continuous monitoring must also be included in a quality assurance program, meeting 10 CFR 61, Appendix B.

\section{SPECIALLY CONTROLLED SUBSTANCES}

\section{Polychlorinated Biphenyls (PCBs) - 40 CFR 761 \& WAC 173-303}

PCB use, handling, and disposal are regulated by the Toxic Substances Control Act (TSCA) for materials containing $50 \mathrm{ppm}$ PCB or greater, or materials containing less than $50 \mathrm{ppm}$ due to dilution. In addition, certain waste containing PCBs in concentrations greater than or equal to 2 ppm and less than 50 ppm may designate as W001 under WAC 173-303 and be regulated as a dangerous or mixed waste.

TSCA PCB wastes are often part of a mixture including other regulated substances (such as dangerous waste or radionuclides); the TSCA regulations do not address or preempt the regulation of non-PCB components of a waste. See HNF-PRO-3152 for additional PCB guidance.

EVALUATION: To be determined. The current assumption is that the grouted melters will not be TSCA regulated for PCB concentration. However, this assumption needs further evaluation. See issues section.

The tank farm waste is currently undergoing analyses for determination of TSCA applicability. It is currently proposed in negotiations with the regulators that the waste in the double shell tanks be declared PCB remediation waste. TSCA applicability for the vitrification plant and waste generated at the vitrification plant (e.g. failed or excess melters) is also being negotiated and must be resolved. If the grouted melters are determined to be or contain TSCA regulated PCB waste (such as PCB remediation waste) a regulatory analyses should be performed to determine if TSCA regulations allow the waste to be disposed in the trench or if additional TSCA approvals are required. This will be addressed on a sitewide perspective, but also must be must be evaluated for failed melters on a case-by-case basis. 
TSCA requires all hazardous commercial products (paints, solvents, process chemicals, etc) to be maintained on a TSCA inventory. Users must input data for the Hanford Site Inventory, when materials are purchased. Some research $\&$ development activities are exempted from TSCA controls for "de minimus" quantities. TSCA guidelines give preference to use and recycling of all controlled materials, to meet Pollution Prevention/Waste Minimization aspects. All chemical users must maintain the Material Safety Data Sheet in a convenient location near point of usage. See HNF-PRO-453 for records and reporting requirements. Use of hazardous materials in a facility process stream is subject to the Waste Minimization evaluation, see later section on Solid Waste, or HNF-PRO-462.

Special considerations apply to handling, packaging, treatment and disposal of mercury. The EPA is currently reevaluating treatment recommendations and standards. Contact the ECO or TSCA SME for issues guidance.

\section{Pesticides, Rodenticides and Herbicides - WAC 16-228/-232 inclusive}

Miscellaneous poisons are controlled by the Federal Insecticide, Fungicide and Rodenticide Act (FIFRA). The Washington State Dept of Agriculture is authorized to implement these regulations. Users must comply with the WAC 16 requirements, for training, usage, handling, storage, disposal and record keeping of items under FIFRA. See HNF-PRO-451 for additional guidance on FIFRA Controls. See HNF-PRO-453 for record keeping and reporting requirements

EVALUATION: Not applicable. The melter unit(s) will not contain these substances. . Some CERCLA-related activities may be in the final closure plans for the 218-E-12B burial ground. Those issues are beyond the scope of this checklist.

\section{WASTE OILS - WAC 173-303-040, -360, -515}

Waste oil is oil that has been used and contains contaminants, which are controlled under RCRA or other authority. Waste oils are not controlled as hazardous substances, unless they also contain other components, which must be controlled as hazardous substances under Federal or State requirements. Controls for the Hanford Site are based only on the contaminant requirements that might be those of mixtures. Petroleum products being stored for eventual use are not considered waste. Special considerations allow waste oils with contaminants to be used for energy recovery, per WAC-173-303-515. Waste oils stored in small/portable containers may be exempted from some storage requirements; those stored in fixed tanks may need to meet design requirements in WAC 173-303-360, or DOE 6430.1A

EVALUATION: Not applicable. The melter units will not contain these substances under the baseline option.

A tertiary alternative to emplace other LLMW in the same trench with the melters will be evaluated by in the strategic planning document. If this alternative were to receive affirmation, then many of the streamlined permit exemptions noted previously would require additional evaluation, and extensive design approvals by both the DOH and Ecology.

\section{MIXTURES - Air Emissions \& Liquid Releases, 40 CFR 302, -355, -372, and WAC 173-303-145, -372}

Specially controlled substances may be subject to release in air (as vapor, droplets or solid particulates). They may be released in liquids as either dissolved or suspended materials. They may even appear as solids within a solid or semi-solid waste matrix. Special documentation and emissions/release estimates may be required as part of the description for normal and upset 
operating conditions. Special reporting protocols must be followed if a release of greater than the reportable quantity (RQ) occurs; [see 49 CFR 172].

Special substances being managed as part of a mixture, especially mixtures involving radioactive components, or within a petroleum carrier product must meet the requirements for the container (design), leak detection, release, administrative management controls, and emissions sampling. These will normally be contained in the Facility Waste Minimization Plan, Facility Emissions Monitoring Plan (FEMP), and the RCRA Part A/Part B permit.

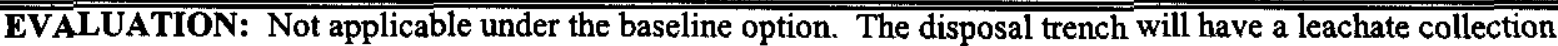
system, however, which will be "hard-piped" to the 200 Area Liquid Effluent Treatment Facility. Due to the "sealed source" designation of the melters, and the assumption that final design intends to meet Land Disposal Restrictions in 40 CFR 268, the leachate will probably be of less than threshold of concern for most, if not all, contaminants.

Under tertiary options, emplacement of non-melter waste might allow some mixture releases, although the trench management would certainly mitigate against this. The trench leachate would still be collected and piped to the same treatment facility.

\section{ASBESTOS}

\section{Asbestos/NOI - BCCAA General Regulation 1, Article 8; 40 CFR 61, Subpart M}

Asbestos is a controlled carcinogen. All work must be done by trained and certified personnel. Any proposed reconstruction, repair, or demolition involving asbestos must be reviewed by $\mathrm{FH}$ Environmental Protection for possible pre-project notification to the Benton Clean Air Authority (BCAA). All notifications will be handled by the central FH Environmental Protection for the entire Hanford Site; see Notice of Intent (NOI) section, following. Refer to HNF-PRO-2595, for details.

EVALUATION: Not applicable. There will be no asbestos used in the melter unit, nor in the design of the disposal trench.

\section{OUTDOOR OR UNCONFINED BURNING}

\section{Burn Permit - WAC 173-425; BCAA, Regulation 1, Article 5}

Any use of unconfined burning requires a permit from the local BCAA obtained through the Hanford Fire Department. Special burn permits are required for demolition or fire training.

EVALUATION: There will be no open burning associated with the melter preparation, nor with the shipment. There will be no open burning associated with the RCRA compliance requirements in operating the trench or with its maintenance and management.

However, there has been an ongoing disposal program for non-contaminated tumbleweeds in the Hanford 200 East Area. This is managed by the landlord function (Dyncorp), separately from the vitrification and burial ground facilities.

Burning permits will be sought regularly, as part of the general landlord responsibilities, but these will be administratively separate from the melter disposal processes. This evaluation will be included in the strategic planning document at its next revision cycle. 


\section{OZONE DEPLETING SUBSTANCES}

\section{Ozone Depleting Substances/Chlorofluorocarbons - 40 CFR 82 Release Prevention; Recovery/Recycle; Certification; Labeling}

Any person who produces, transforms, destroys, imports or exports a controlled (ozone depleting) substance (e.g., chlorofluorocarbons [CFCs]) must perform the required reporting, training, and operations specified in 40 CFR 82. See HNF-PRO-2595 for details. Processes involving CFCs will usually contribute to a secondary waste stream, for which Pollution Prevention/Waste Minimization evaluation must be applied.

EVALUATION: Not applicable. There will not be any ozone depleting substances associated with the final melter package, which is sent to the disposal trench.

\section{SOIL-COLUMN WASTE WATER DISPOSAL}

\section{State Waste Discharge Permit (SWDP) - WAC 173-216}

The SWDP is required before waste materials from industrial, commercial, and municipal operations are discharged into ground and surface waters of the state and into municipal sewerage systems. It is DOE's policy that no new wastes or wastewater will be disposed uncontrolled to the soil column. A monitoring system/plan is needed for this category of disposal. An SWDP is not required for discharges of pollutants into navigable waters already covered by an NPDES permit program.

EVALUATION: Not applicable under the baseline option. The disposal trench design will include capability to collect leachate from the volume occupied by the melters, and transport it by a hard piped system (RCRAcompliant, double encased) to the 200 East Area Effluent Treatment Facility. No discharges to the soil column are expected.

Under a secondary option, if the melter were required to be transported to the trench and processing for final disposal done there, a separate and extensive permitting effort would be necessary. The disposal trench would be permitted only for disposal under the baseline option. This is a straightforward process. Under the secondary option(s) the trench must also be permitted as a treatment unit, which is far more complex.

\section{Approval of engineering reports, plans, and specifications and operating and maintenance manual - WAC 173-240}

Before construction or modification of those domestic or industrial wastewater facilities requiring Ecology wastewater discharge permits, engineering reports, plans, and specifications for the project must be submitted to and approved by Ecology. Operation and maintenance manuals must be submitted before construction is completed.

EVALUATION: Not applicable under the baseline option. However, informal notification to Ecology is recommended, in order to expedite the overall project schedule. 


\section{Underground Injection Control (UIC) Permit/Registration - WAC 173-218}

Authorization by Ecology of fluids injected through wells has been restricted to wells operational before February 29, 1984. New discharges of uncontaminated storm water and groundwater return flow, unaltered except for temperature from a ground water heat pump used for heating or cooling, are the only discharges that are not prohibited. These discharges must be registered with Ecology before construction begins.

EVALUATION: Not applicable. The project will not use underground injection wells.

\section{DOMESTIC WASTE WATER DISPOSAL}

\section{Septic System approvals/permits (<14,500 gpd design capacity) - WAC 246-272}

Plans and specifications for construction of a new sanitary sewer system or modification of an existing system shall be submitted and approved by the DOH before construction or entering into a contract for construction. Once the installation is complete, a professional engineer registered in Washington State must certify that the installation has been installed according to plans and specifications approved by the $\mathrm{DOH}$. In addition, an operation and maintenance manual must be submitted to the DOH.

\section{Septic System approvals/permits (>14,500 gpd design capacity) - WAC 173-216; WAC 173-240}

Septic systems with design capacities greater than 14,500 gpd are governed by State Waste Discharge Permits (WAC 173-216) and the engineering report, plan, and specification approval process described in WAC 173-240.

\section{Discharge Standards and Effluent Limitations for Domestic WasteWater Facilities - WAC 173-221}

Effluent from domestic wastewater treatment facilities, except subsurface septic tank systems with capacities less than 14,500 gal per day, must meet the discharge standards established in this regulation.

Note: The DOH has taken the following position regarding modification or expansion of a drainfield located in the area of a known subsurface chemical hazard that could potentially cause the plume to harm groundwater: no modification or expansion will be allowed, consistent with regulations established for larger on-site sewage systems, preliminary report requirements (WAC 246-272-080).

\section{Pretreatment Permit - 40 CFR 403}

New wastewater discharges to the City's sewage treatment plant may be required to submit permit applications to the City of Richland before discharging sewage, industrial waste, or other waste. Whether a permit application is needed depends on whether the activity is considered a Significant Industrial Discharge by the City or fits a national pretreatment category. 


\section{Operator Certification - WAC 173-230}

Every operator in responsible charge of a domestic wastewater treatment plant is required to be certified at a level equal to or higher than the classification rating of the treatment plant being operated. Septic systems are excluded from requiring certified operators.

EVALUATION: Not applicable under the baseline option. Operations at the vitrification facility will allow workers there to use the facility's disposal system. There will not be any wastewater treatment or sanitary sewer associated with design, operation or closure of the disposal trench.

\section{SURFACE WASTE WATER DISPOSAL}

\section{NPDES Permit - 40 CFR 122}

Any discharge of pollutants to waters of the United States is required to have an NPDES permit before operation. The regulatory agency responsible for issuance of this permit is the EPA.

\section{Ecology Certification of an EPA NPDES Permit - 40 CFR 121}

EPA may not issue an NPDES permit until a certification is granted or waived by Ecology. Ecology must certify that all conditions necessary to ensure compliance with applicable federal and state water quality standards are met.

\section{Storm Water Discharge under EPA NPDES General Permit - 57 Federal Register 175, September 9, 1992}

The Hanford Site is covered by two storm water permits. Permit WA-R-00-000F covers storm water runoff for the Hanford Site as a whole. Permit WA-R-10-000F covers storm water runoff from construction projects. If there is a potential for storm water to reach the river from construction activities, an NOI for authorization under the EPA general permit and a storm water disposal permitting plan (SWDPP) must be in place at least two days before discharge from new construction sites (those begun after October 1, 1992).

EVALUATION: There will be no NPDES discharges to surface waters as part of the melter preparation, transport and emplacement in the disposal trench.

There may be some rainwater/snowmelt that collects in the bottom of the disposal trench. This will be collected by the leachate collection system and sent to the 200 East ETF; see discussion under the State Waste Discharge Permit, above.

\section{U.S. Army Corps of Engineers (USACE) Permit - 33 CFR 325}

Discharging dredge and fill material into waters of the United States requires a permit from the USACE, before initiating the activity.

\section{Wild and Scenic Rivers: Section 10 Permit - 33 CFR 322}

Permits are required before the construction of structures and the performance of other activities in or adjacent to navigable waters. Certain activities are covered by nationwide permits rather than individual Section 10 permits. However, any work in an area designated as a "study river" 


\section{RPP-7094 REV 0}

for possible inclusion in the Wild and Scenic River System, such as the Hanford Reach, must obtain an individual Section 10 permit.

\section{Nationwide Waterway Permits - 33 CFR 330}

Nationwide Permits are general permits issued by the USACE designed to regulate with little, if any, delay or documentation, certain waterway activities having minimal impacts. These permits are not applicable for projects within a Wild and Scenic River study area.

EVALUATION: Not applicable under the baseline option.

\section{Hydraulic Projects Permit - WAC 220-110}

Any construction or other work that will change the natural flow of a river, including the addition of treated effluent waste water that will increase the natural flow, is required to obtain a hydraulic project approval from Washington State Department of Fisheries.

\section{Shoreline Development Permit - WAC 173-14 to -20}

A permit for developing the shoreline is required before construction for shorelines not federally owned, but under lease, easement, license, or other similar federal property rights short of fee ownership.

\section{Aquatic Lands Lease - WAC 332-30}

Aquatic land activities that interfere with the general public's use of state-owned tidelands, shorelands, and beds of navigable waters, require authorization before construction from the State of Washington Department of Natural Resources by way of agreement, lease, permit, or other instrument(s).

\section{Hanford Reach Study Act Notification - PL 100-605}

Proposed construction within one-quarter mile of the Columbia River shoreline inside the Hanford Reach Area is subject to consultation and coordination with the National Park Service.

EVALUATION: Not applicable under the baseline option. The disposal trench is planned for the 218-E-12B burial ground, which is not controlled by the shoreline protection requirements.

\section{Surface Water Quality Modification Approval - WAC 173-201}

A permit, directive, or order, as appropriate, must be obtained from Ecology before undertaking an activity that will temporarily reduce water quality below the criteria and classifications established for the stream.

Categorical Standards: WAC 173-200 \& 40 CFR $141 \& 143$ Effluent Guideline and Standards - 40 CFR 405 to 471

All liquid discharges to the environment must essentially meet the state Drinking Water Quality Standards in WAC 173-200. If liquid effluents are being discharged under a specific 
concentration limit, they may be subject to strict laboratory sample analyses of numerous contaminants. Specific analysis methods for these are specified in 40 CFR $141 \& 143$.

The regulations list industry categories associated with the National Pollutant Discharge Elimination Standards (NPDES) permit program. The regulations prescribe effluent limitation guidelines for existing sources, standards of performance for new sources, and pretreatment standards for new and existing liquid effluent sources.

EVALUATION: Not applicable under the baseline option. All leachate collected from the melter disposal area will be hard-piped to the 200 East Area ETF. The ETF will have responsibility to meet whatever disposal requirements are currently in place.

\section{DRINKING WATER SUPPLY}

\section{Approval of Engineering Reports, Plans and Specifications - WAC 246-290}

Approval of engineering reports, plans, and specifications for a drinking water supply system is required before construction.

\section{Drinking Water System Identification - WAC 246-290}

New drinking water systems must obtain an identification number from the $\mathrm{DOH}$ before operation.

\section{Drinking Water System Operator Certification - WAC 246-292}

Operators in direct responsible charge of certain public water systems must be examined and certified for their competency on state requirements and standards before operating the system. Systems requiring certified operators include systems with 100 services at any one time; or systems serving 25 or more persons where the water is supplied from a stream, lake, or other surface water source and the systems are required by law to use a water filtration system.

EVALUATION: Not applicable under the baseline option. If drinking water is required for workers during the transport and emplacement of the melters, it will be provided using portable containers.

\section{RADIOACTIVE WASTE}

\section{Management of Radioactive Waste - DOE Order 5820.2A, DOE Order 435.1 Packaging Criteria - HNF-EP-0063}

All radioactive waste must be managed/stored in a way that prevents uncontrolled release of contaminants to the off-site areas. Standards for packaging of wastes for both transport and storage are included in HNF-EP-0063 (latest revision). High-level Waste (HLW) is a source designation, for the first stage of waste separated from processing irradiated nuclear fuel and other similar materials. High-level waste must not be confused with high-activity waste; handling/design requirements apply differently. Requirements for HLW management, handling, packaging, treatment, transport, and storage are summarized in DOE Order 5820.2A, and its associated references. DOE Order 435.1 will replace $5820.2 \mathrm{~A}$ at Hanford, being phased-in by the year 2001. 


\section{RPP-7094 REV 0}

Facilities whose primary function is that of management of HLW must be designed in accordance with special requirements in DOE Orders 435.1, 6430.1A and their references. In general, HLW will have both a radioactive component (controlled by the Atomic Energy Act) and a hazardous material component (controlled by RCRA). Congress (10 CFR 962) decided that both sets of controls must be applied to HLW projects. DOE Policy requires that all HLW will be safely stored, treated, and disposed of in accordance with all applicable requirements, particularly those of the EPA (40 CFR 191) and the affected State(s).

Radioactive waste that does not meet criteria for HLW or TRU is considered low level. Treatment, storage and disposal processes must meet applicable standards for clean air, clean water, and protection of the environment just as if they were general RCRA controlled wastes. All facility construction, both new or modification, to handle radioactive wastes must meet design criteria in DOE $6430.1 \mathrm{~A}$, or similar standards.

DOE Order 435.1 requires that the facility develop a Performance Assessment (PA) document for the estimated exposures that the public might receive over long-range operation of the disposal facility. It also requires a Comprehensive Analysis (CA) for the same goals for a group of waste units in general proximity. PNNL has been developing the CA. The PA is developed by a multi-discipline team from the WMP, under the lead of the Systems Engineering organization. Some environmental data will be required to complete these responsibilities.

EVALUATION: DOE policy (Order 435.1) is that only DOE-controlled facilities will be used for disposal of LLW or LLMW. The DOE 435.1 will require all newly generated waste to also have a "path-forward" for disposal, prior to facility operations. The NEPA planning documents have identified that vitrification of the Hanford tank waste is the preferred disposal option.

The LAW melters will be sufficiently processed at the facility, to be designated as low-level sealed sources, and will also meet the LDR (40 CFR 268). The HLW melters that reach their design life and are excessed will be similarly packaged as contact-handled LLW.

Failed melters, which have more than minimal amounts of waste and glass-forming materials, present the greatest challenge. The vitrification design team has states that all excess glass material and associated tank waste will be removed to the maximum capability, consistent with ALARA. Failed melters will be evaluated on a case-by-case basis for the designation as non-TRU waste. DOE/HQ would be notified prior to any waste generation that has no path forward for disposal.

The HLW Melters that must be designated as TRU can only be sent to WIPP for final disposition. That event is currently outside the scope of this checklist.

DOE 435.1 requires that every nuclear facility develop a radioactive waste management plan, a PA \& CA. A sitewide implementation plan for 435.1 has been issued [DOE/RL-2000-25, rev 1]. Applicable data will be drawn from the final design and several Part $B$ sections, for inclusion in a revision of the PA \& CA when required. This will be done for the disposal trench after identification of the requirements, and will become part of the trench operational criteria.

\section{HIGH-LEVEL WASTE}

\section{Reprocessing of Spent Nuclear Fuel - Atomic Energy Act, DOE Order 5820.2A, 10 CFR 962 Design Criteria - DOE Order 6430.1A}

High-level Waste (HLW) is a source designation, for the first stage of waste separated from processing irradiated nuclear fuel and other similar materials. HLW must not be confused with high-activity waste; handling/design requirements apply differently. Requirements for HLW 
management, handling, packaging, treatment, transport, and storage are summarized in DOE Order 5820.2A, and its associated references. Facilities whose primary function is that of management of HLW must be designed in accordance with special requirements in DOE Order 6430.1 A and its references. In general, HLW will have both a radioactive component (controlled by the Atomic Energy Act) and a hazardous material component (controlled by RCRA). Congress (10 CFR 962) decided that both sets of controls must be applied to HLW projects. DOE Policy requires that all HLW will be safely stored, treated, and disposed of in accordance with all applicable requirements, particularly those of the EPA (40 CFR 191) and the applicable State(s).

HLW is also classified as transuranic (TRU) waste if the waste form exceeds the activity level of 100 nanocurie/gram from TRU elements, at the time of final stage processing, and before dilution for pumping. Most TRU processes must also meet criticality safety controls, but these are not part of the environmental compliance issues. Facility permits will incorporate all applicable compliance criteria.

Treatment, storage and disposal processes must meet applicable standards for clean air, clean water, and protection of the environment just as if they were general RCRA controlled wastes. Facilities that have formerly treated and/or stored HLW may be decontaminated under either RCRA or CERCLA authority. A special review of environmental requirements for the D\&D, plus final closure must be made in a closure plan, which is outside the scope of this checklist.

\section{Low Level Radioactive Waste}

Radioactive waste that does not meet criteria for HLW or TRU is considered low level waste (LLW). Treatment standards, storage, handling and packaging criteria are summarized in the general regulations.

EVALUATION: The vitrification design team has indicated it is the intent to process both excessed and failed melters sufficiently to enable the final unit to meet RCRA LDRs (40 CFR 268). They will also be able to be transported as contact-handles waste, (e.g., $<200 \mathrm{mrem}$ at contact, and $<100 \mathrm{mrem}$ at $30 \mathrm{~cm})$.

The final design of melter units and facility processes will be thoroughly evaluated against these target goals, prior to startup.

Failed HLW Melters that can not be designated as non-TRU must be either extensively recycled, or provided with sufficient additional packaging to be able to be sent to the WIPP, in New Mexico. This alternative is outside the scope of the present checklist.

\section{SOLID WASTE}

\section{Solid Waste Handling Facility Permit - WAC 173-304 Pollution Prevention/Waste Minimization - DOE 5820.2A, DOE 5400.1, DOE 5400.3, Ex Order 13101}

Solid waste TSD sites or facilities (i.e., landfills, land spreading, piles, surface impoundments, and recycling facilities) must obtain approval from Ecology via the comprehensive solid waste plan, and from the jurisdictional county health department before construction. Even inert wastes may be regulated by some part of the RCRA act, and actions must usually be RCRA-compliant; (see RCRA section, following). Benton 
and Franklin County Health Departments will be notified, since they may also provide emergency response capability.

All facilities are covered by the Hanford Site Waste Minimization and Pollution Prevention program plan (DOE/RL-91-31). New facilities must also develop a Pollution Prevention/Waste Minimization strategy, and incorporate guidelines from HNF-PRO-462 into any operations prior to startup. Legislative drivers are in the referenced procedure. . The executive order requires all federal facilities (and contractors) to include: elimination of virgin materials, use of biobased products, use of recovered materials, reuse of product, recycling, environmentally preferable products, waste prevention, toxicity reduction, life cycle costs and ultimate disposal.

EVALUATION: The final melter unit, when ready for disposal, must meet the RCRA Land Disposal Requirements (40 CFR 268). Specific details of this target will be defined during the vitrification facility final design. The Melter Disposal Trench will be designed as if it will only be receiving sealed source, contact-handled items, which already meet the LDRs; [see assumptions, in the project scope section]. Disposal criteria for the melters will be addressed in a revision of the HSSWAC (ref: 0063 ).

Pollution Prevention \& Waste Minimization will be addressed during the vitrification facility design process and is not part of this effort. A decision to make the melter one enclosed unit eliminates the alternatives associated with size reduction. This is related to the designation of the units as "sealed" by Ecology and DOH.

\title{
DANGEROUS WASTE
}

\author{
Dangerous Waste Permit - WAC 173-303; 40 CFR 264, 265, 270 \\ Resource Conservation and Recovery Act (RCRA) Part A - WAC 173-303-805, \\ Part B - WAC 173-303-806
}

Facilities that treat, store, or dispose (TSD) of regulated dangerous waste must obtain the necessary permits. Whether a waste is a regulated dangerous waste must be determined in accordance with WAC 173-303-070 designation procedures. Existing Hanford Facility TSD units are in process of obtaining permits in accordance with schedules and procedures identified in the Tri-Party Agreement.

New Hanford Facility TSD units that are not identified in the Tri-Party Agreement will require development of a permitting plan to detail the strategies and schedules to be used for developing the necessary dangerous waste permits. This plan must be developed early in the project development phase, strategies and schedules to be used for developing the necessary dangerous waste permits for new TSD units will need to be discussed with the appropriate regulatory agencies to gain their concurrence.

\section{Generation and Management of Dangerous Waste - WAC 173-303, 40 CFR 264, $265,268,270$}

Facilities that generate regulated dangerous waste must meet the management requirements for that waste. Whether a waste is a regulated dangerous waste must be determined in accordance with WAC 173-303-070 designation procedures. Any "unknown waste" must be managed as a dangerous waste, until analyzed and shown to be 


\section{RPP-7094 REV 0}

exempted from these requirements. Generator activity records must meet requirements in WAC 173-303-210.

These requirements apply to all Hanford facilities, both new and existing. These requirements also apply to new and existing facilities permitted or being permitted as TSD facilities under WAC 173-303. Accumulation of wastes implies "generator activities" and associated responsibilities; see HNF-PRO-5122. Regulations require that any "storage of wastes" must be in either a permitted TSD unit or in a satellite accumulation area.

EVALUATION: The status of the melter, at the time of transport is an issue that must be agreed to with the State.

The status of the disposal trench will be designated as a disposal facility only, under the baseline option. If melters were to be transported to the trench for processing, then the trench would need to be permitted as a treatment unit, which would greatly extend the permitting effort.

The tertiary option, allowing multiple smaller MW containers to be intermingled with the melters would also add to the complexity of the permitting process, although if this were to be delayed until after the melter disposal operations is complete, then a single revision of the trench permit might be negotiated with the external regulators. Details of such an option are outside the scope of this checklist.

Designation of Contaminated Environmental Media and Debris (contained-in policy) - 40CFR 260, WAC 173-303-040, -070, \& -072

Environmental media and debris contaminated with a listed dangerous waste shall be managed as a dangerous waste until the media has been either:

- Delisted by the EPA pursuant to 40 CFR 260.22, and by Ecology pursuant to WAC 173-303$072(1)-(4)$, or

- Determined by Ecology to no longer contain a listed waste (contained-in determination) for environmental media or by the EPA for hazardous debris, and, does not display a characteristic or criteria.

Process knowledge may also be used to designate waste in lieu of sampling and analysis.

When requested to perform a contained-in determination, Ecology has historically used the Model Toxics Control Act residential standards to make decisions on applying the "contained-in" policy.

If environmental media contaminated with listed waste meets the definition for debris contained in WAC 173-303-040 (and 40 CFR 268.2), the alternative treatment standards of 40 CFR 268.45 provide another option for management. Hazardous debris that has been treated in accordance with extraction or destruction technologies of 40 CFR 268.45 is deemed to no longer contain a listed waste; see WAC 173-303-070(2)(c) and 40 CFR 261.3(f) for debris; and "Contained-in policy" set forth in Ecology memo dated February 19, 1993. 
EVALUATION: This designation issue will need to be determined by interfacing with Ecology, and the melter design team. The resultant strategy will impact the permits needed for transport and disposal of the melters.

Compliance with Existing Permit Conditions in the Dangerous Waste Permit - WAC 173-303 Resource Conservation and Recovery Act (RCRA) Part A - WAC 173-303-805, Part B WAC 173-303-806

There are requirements in the HF RCRA Permit that apply to all new and existing Hanford facilities. A facility does not necessarily need to have a Part A (interim) or Part B (final) permit in place to be subject to the requirements in the Hanford Facility RCRA Permit.

Existing Hanford facilities with Part A, Form 3 Permit applications must comply with requirements in the Part $\mathrm{A}$.

Current Hanford facilities with Part B information incorporated into the Hanford Facility RCRA Permit must comply with the requirements in the Part B.

\section{Satellite and <90-day Accumulation Areas - WAC 173-303-200, 173-303-170}

Small quantities of hazardous waste may be accumulated in a Satellite Accumulation Area (SAA), until 55 gallons is reached; (1 quart for extremely hazardous waste). Only one category of waste may be accumulated in a single container (drum), but there is no limit on the number of separate drums; each drum being a distinct SAA for a particular waste stream. The facility ECO will maintain a current list of all such SAAs being used, and updates the central point of contact (FH Environmental Monitoring and Reporting) quarterly. If a temporary SAA is set up for a specific task/period of less than 7 days, it will not need to be reported to the central contact.

As soon as the accumulation limit is reached, the facility must transfer the waste in an approved container to a permitted TSD unit. This will normally be a $<90$-day storage pad. Further treatment for compliance to meet disposal standards may be made at the $<90$-day pad, before shipment to a final storage/disposal facility. Both the SAA and 90-day areas must be inspected weekly, even if no waste is currently within the areas. See HNF-PRO- 5122.

EVALUATION: The disposal trench will be included in the HF RCRA permit after final design phase is completed; no direct action is required at the time of compiling this checklist. The vitrification facility will have satellite accumulation areas under its own control; no additional effort is required on this item, either.

\section{Notice Of Intent (NOI) - WAC 173-303-281}

A NOI is required for proposed RCRA TSD facilities or expansion at an existing RCRA facility. Expansion includes enlargement of land surface area, the addition of new dangerous waste processes, or an increase in overall design capacity. The NOI contains preliminary information concerning the proposed facility and/or expansion. The NOI requires a general process description, operating capacities, waste type, a topographic map, and a statement of environmental conditions, which could include a SEPA environmental checklist or a SEPA adoption letter. If 
expansion of a fully permitted RCRA facility is desired, a Class 3 modification is used, rather than the NOI.

EVALUATION: Since the MWDU Part B permit is expected to be in place by Dec 2002, any modification to the 218-E-12B will use a class 3 modification. The melter disposal will not require a NOI.

The issue of including added MW items in the disposal trench at time of closure might require changes in the permitting, but that does not impact the baseline assumptions. It is recommended that an interface with the Ecology regulators be sought to seek concurrence on this approach.

\section{Construction/Expansion of Surface Impoundments, Waste Piles, or Landfill Units - WAC 173-303-335 Construction Quality Assurance Program - DOE 5700.6C}

A construction quality assurance (CQA) program -- meeting requirements of DOE $5700.6 \mathrm{C}$ is required for all surface impoundment, waste pile, and landfill units required complying with dangerous waste requirements in WAC 173-303-650, -660, and -665. The program must ensure that the constructed unit meets or exceeds all design criteria and specifications in the RCRA permit. The program must be developed and implemented under the direction of a CQA officer who is a registered professional engineer. The owner/operator must submit a certification to Ecology signed by the CQA Officer -- that the plan has been carried out and that the unit meets the WAC 173-303-650, -660,-665; and the procedure in WAC 173-303-810 (14) has been completed, before any waste is accepted into the unit.

Waste may be disposed in landfills or near-surface disposal units only if they meet the land disposal restrictions (LDR) presented in 40 CFR 264 and 265. Wastes must be packaged to meet special air, vapor, or particulate release restrictions. Waste packaging must also be sufficient to protect groundwater. The disposal unit must also be managed as a RCRA compliant TSD unit per WAC 173-303.

Waste liquids may be accepted for temporary storage in surface impoundments if the requirements of 40 CFR 265, Subpart K and 40 CFR 268.4 are met.

\section{Nonstandard Methods, RD\&D Permit, Modification and Waivers - WAC 173-303-500 to $607,809 \& 830$}

The Research, Development \& Demonstration permit is intended to provide flexibility for TSD units that propose to use an innovative and experimental technology for RCRA wastes. The RD\&D permit is similar to the Part B, and is prepared according to WAC 173-303-809 if the proposed process is not covered in WAC 173-303 sections 500-670 (inclusive).

Permit modifications and waivers from existing RCRA TSD operations are allowed. Modification/waiver applications are covered in WAC 173-303-830, and HNF-PRO-454, for RCRA waste handling guidelines.

EVALUATION: The disposal trench will need a formal designation as a TSD facility. It will require a construction QA program, which will also become part of the final Part B class 3 modification submittal.

A secondary option for trench design would include seeking a waiver from the requirement for a double liner, similar to the naval reactor disposal trench within 218-E-12B. The state regulators must concur with the use of this option, which would also requite delisting any liquids collected by the trench as being non-contaminated. There is no intent to seek nonstandard methods approval for the disposal trench at the time of developing this checklist. 


\section{UNDERGROUND STORAGE TANKS}

\section{Underground Storage Tank (UST) Permit - WAC 173-360}

After July 1, 1991, no UST system, as defined in WAC 173-360 (miscellaneous underground tanks), shall be operated without a valid permit from the regulatory agency, unless regulated under other more stringent federal guidelines. This section covers any tank for managing regulated substances, which is not specifically regulated by other sets of either federal or state guidelines. Inspections, leak detection, record keeping, reports and notifications are similar to those of other tanks. The tank system also includes any ancillary piping or equipment needed to fully operate the tank.

EVALUATION: Not applicable. This requirement is outside the scope of this project.

NOTE: The Hanford HLW tanks are excluded from this requirement; it applies primarily to petroleum and process chemical tanks. Existing tanks must be upgraded and new tanks must meet design/construction, leak detection, inspection, and administrative record guidelines. 


\section{RPP-7094 REV 0}

This page intentionally left blank. 
RPP-7094 REV 0

\section{APPENDIX G}

DECISION ANALYSIS 
RPP-7094 REV 0

This page intentionally left blank.

G-ii 


\section{DECISION ANALYSIS}

Decision analysis is a structured, quantitative approach to evaluating decisions with complex alternatives, uncertain outcomes, and competing objectives. First developed at Harvard and Stanford universities in the 1960s, decision analysis has since grown in commercial use because of a solid quantitative foundation and the availability of inexpensive computers capable of performing iterative calculations quickly and presenting the results graphically.

Decision analysis is typically performed in a three-step process: (1) framing the problem, (2) data collection and modeling, and (3) analysis and evaluation. The process can be conducted at any scale, from a strategic level that is relatively qualitative or subjective to an extremely detailed level based upon large amounts of empirical data. A graduated decision analysis effort, progressing from strategic to more detailed, is proposed over time for the vitrification melter decision.

During the first step, framing the problem, domain experts meet to define the decision(s) and choose the attributes relevant to the decision. DOE Order 420.1(a), Life Cycle Asset Management, and DOE-FM Guideline \#2, LCAM Decision Criteria, define some important decisions for any Hanford project. Four critical decisions are defined in Order 430.1(a): CD-1, Mission Need; CD-2, Design; CD-3, Construction, and ; CD-4 Operations. Decision-makers are commonly most concerned about two attributes, cost and schedule.

A scoping level effort for the decision analysis task was performed in FY00 to support the development of a strategic plan and to demonstrate the potential benefits of future decision analysis to the project. During a framing workshop, it was decided to focus on CD-2, design decision as an example analysis. Although many attributes were discussed during the workshop, the preliminary analysis was conducted for a single attribute, cost.

Decision analysis products can be used for many purposes, and their form depends upon the intended application. The most recognized forms are probably the influence diagram and the decision tree.

The influence diagram is the initial product of a framing workshop. In our framing workshop, four decisions were recognized as having a major influence on CD-2: trench location (alternatives are 200E or $200 \mathrm{~W}$ ), transporter (alternatives are submarine, lease, use vitrification contractor's transporter, or purchase), trench design (alternatives are dedicated or multi-use), and permitting (alternatives are trench permitted for RCRA disposal only or for TSD). The strategic plan baseline alternatives are underlined. The workshop influence diagram is illustrated below.

An influence diagram can be transformed into a decision tree by applying quantitative estimates for the desired attribute(s) to each alternative. In a deterministic model, a point value is estimated for each alternative. Iterative summations are performed to calculate the value for all possible alternative combinations. For the strategic plan, we have a baseline set of decisions and a baseline cost estimate based upon those specific alternatives. The baseline cost is presented elsewhere in this report. For alternatives other than the baseline, ROM costs were estimated. One decision, transporter was explored in more depth than the others. 


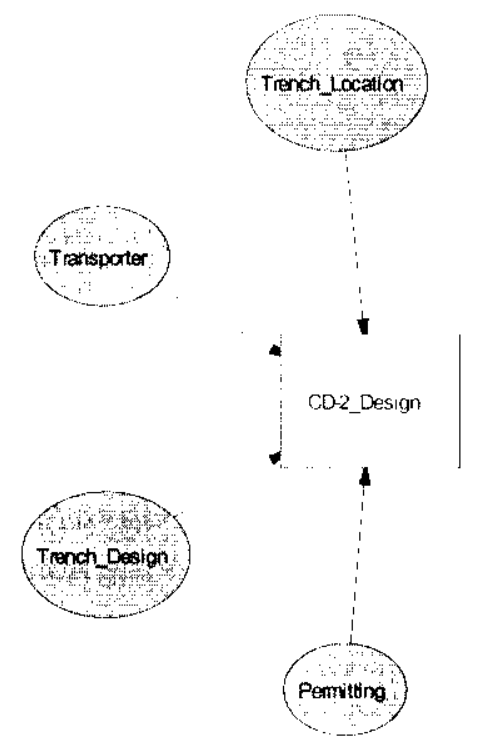

A probabilistic model is usually more useful to decision-makers than a deterministic one. To transform a deterministic model into a probabilistic one, the probability of each altemative is estimated. For any decision, the sum of probabilities for all alternatives must equal one. For the strategie plan, the baseline alternatives have the highest probability of occurrence. The other altematives are less likely to occur. Probabilities for the alternatives for one decision, transporter, were explored in some depth. Probability values for all other altematives were estimated by the decision analyst. The decision tree resulting from the framing workshop and interviews with transportation system engineers is illustrated adjacent.

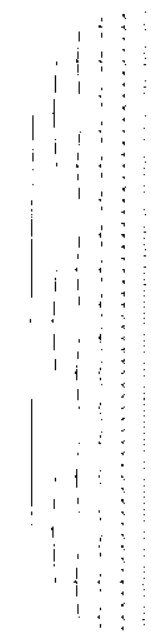


The additional value that is obtained from the probabilistic model is the ability to perform Monte Carlo simulations and then to (1) establish the confidence interval for a given set of alternatives and (2) perform a sensitivity analysis to determine which decisions have the greatest influence on the attribute of interest. The value of sensitivity analysis is to focus management attention on a smaller set of decisions that have the greatest influence on the attribute of interest (typically cost or schedule). The value of establishing a confidence interval for a given set of alternatives is enable contingency planning that recognizes risks outside of the baseline plan. For example if one wishes to plan for the baseline with a $90 \%$ probability of success, one would budget not for the baseline

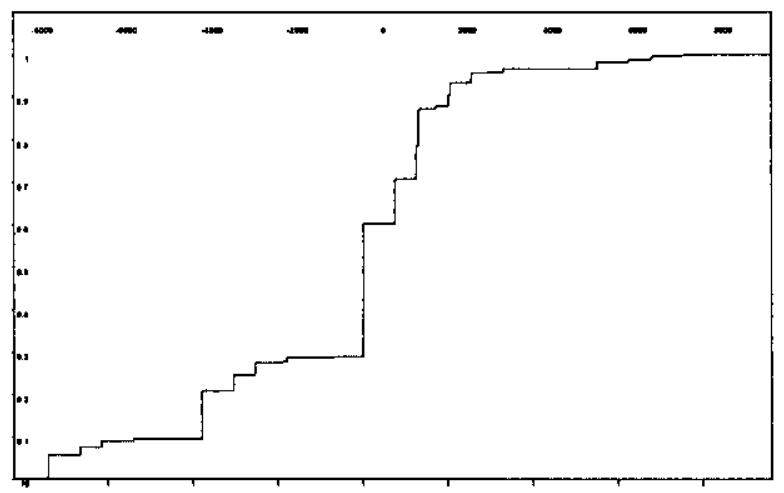
cost, but for the baseline cost plus additional contingency funds to account for the occurrence of some non-baseline alternatives. The contingency curve developed during FY00 is illustrated adjacent and is discussed in detail in the preliminary results section, following.

This decision analysis method of contingency planning differs significantly from the successpath variance method of contingency planning that has been used in the recent past at Hanford (for example, on the privatization project). In the success-path variance method of contingency planning, a single set of alternatives are selected, costs estimated, and scheduled. Cost and schedule variances for each task on the success path are estimated, and a Monte Carlo simulation exercised on a probabilistic model of those variances. The disadvantage of the success-path variance method of contingency planning is that alternatives off of the success path are not evaluated. If events off the success path occur, they can have catastrophic results. This proposed decision analysis method of contingency planning enables decision-makers to recognize the probable cost of alternatives not on the baseline and to plan for contingency funding at a confidence level that satisfies their risk tolerance.

\section{Preliminary Results FY00}

FY00 decision analysis results are preliminary because the effort was less than full scope and the results have not been subjected to peer review. Reduced scope was chosen to reduce FY00 cost for the effort and to decide if this was an effective means for strategic planning. Scope reduction included examination of only CD-2 decision, and evaluating only the transportation alternatives in detail. ROM estimates of cost and probabilities for other CD-2 alternatives were made by the decision analyst to permit a trial decision to be evaluated.

Four decisions were recognized as having a major influence on CD-2: trench location (alternatives are $200 \mathrm{E}$ or $200 \mathrm{~W}$ ), transporter (alternatives are submarine, lease, use vitrification contractor's transporter, or purchase), trench design (alternatives are dedicated or multi-use), and permitting (alternatives are trench permitted for RCRA disposal only or for TSD). Baseline alternatives are underlined. 
Costs of each of the transporter alternatives were developed at a same level of detail as the baseline, and with consistent assumptions. Assumptions and costs are described in detail in the transportation section of this strategic plan. Transportation engineers voted on the probability of each alternative, and pooled results are tabulated below. Cost attributes are tabulated relative to the baseline: a positive value indicates a cost greater than the baseline, a negative value indicates a cost less than the baseline. Costs are in \$K.

\begin{tabular}{|l|c|l|c|c|}
\hline Alternative $\rightarrow$ & $\begin{array}{l}\text { Use Submarine } \\
\text { Transporter } \\
\text { (baseline) }\end{array}$ & $\begin{array}{l}\text { Use } \\
\text { Vitrification } \\
\text { Contractor's } \\
\text { Transporter }\end{array}$ & $\begin{array}{l}\text { Lease a } \\
\text { Transporter }\end{array}$ & $\begin{array}{l}\text { Purchase a } \\
\text { Transporter }\end{array}$ \\
\hline Probability $\rightarrow$ & 0.55 & 0.1 & 0.15 & 0.2 \\
\hline $\begin{array}{l}\text { Cost difference } \\
\text { to baseline } \rightarrow\end{array}$ & 0 & $-7,400$ & $+1,300$ & $-3,800$ \\
\hline
\end{tabular}

In a similar fashion, the decision analyst proposed alternatives for three other decisions necessary for CD-2 and made ROM estimates for costs and probabilities. The values used were:

\begin{tabular}{|l|c|c|c|c|c|c|}
\hline Decision $\rightarrow$ & \multicolumn{2}{|c|}{ Trench Location } & \multicolumn{2}{c|}{ Trench Design } & \multicolumn{2}{c|}{ Permitting } \\
\hline Alternative $\rightarrow$ & $200 \mathrm{E}$ & $200 \mathrm{~W}$ & Dedicated & Multi-use & Disposal & TSD \\
\hline Probability $\rightarrow$ & 0.95 & 0.05 & 0.8 & 0.2 & 0.75 & .025 \\
\hline $\begin{array}{l}\text { Cost difference to } \\
\text { baseline } \rightarrow\end{array}$ & 0 & 5,500 & 0 & 1,250 & 0 & 750 \\
\hline
\end{tabular}

The model was calculated 1,000 times, based on randomly decisions selected in proportion to the probability distributions tabulated above. The histogram produced by these 1,000 events was transformed to a cumulative probability curve illustrated adjacent.

This curve might be used by a decision-

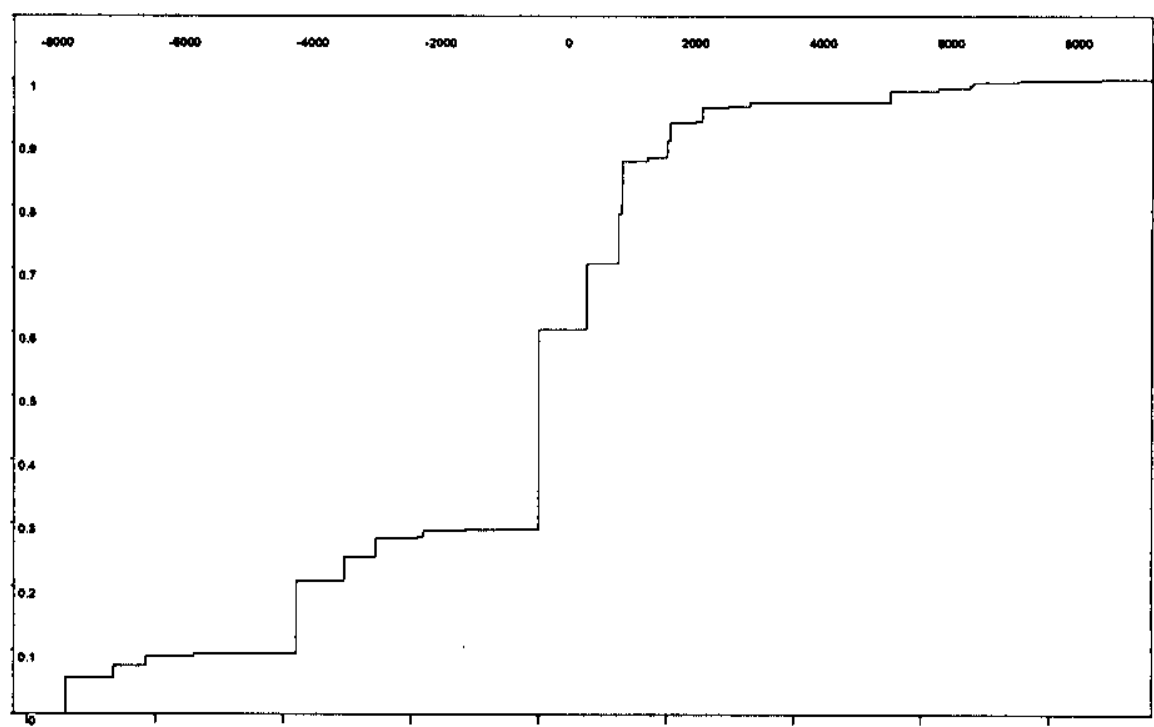
maker in the following manner. A baseline budget provides about a 50-50 probability of success, and there is a substantial probability (about 0.3 ) that the project will be accomplished for less than the baseline budget. For a contingency of about $\$ 1,500 \mathrm{~K}$ above the baseline cost, the decision-maker is $80 \%$ confident that the project will be completed at or below budget. The difference in contingency 


\section{RPP-7094 REV 0}

fee between an $80 \%$ and $90 \%$ confidence level is insignificant. It should be emphasized that these conclusions are based on less than complete scope, have not been subjected to peer review, and are for illustrative purposes only.

\section{Plans for FY01}

The major activity in FY01 is alternative generation analyses (AGA), which will generate a broad set of alternatives for CD-2, -3 , and -4. AGA will also develop costs and schedules for the alternatives considered. Participation by a decision analyst in AGA activities will capture these data and, through periodic brief workshops, capture probability estimates. Decision analysis will be used to develop contingency planning for project cost and schedule for CD-2, -3 , and -4 . The results of FY01 efforts will be used by decision-makers to select the best alternative strategy for continued development in subsequent years. The task is expected to require 0.75 FTE during FY01.

This method differs significantly from the success-path variance method of contingency planning that has been used in the recent past on the privatization project. This proposed decision analysis method of contingency planning enables decision-makers to recognize the probable cost of alternatives not on the baseline and to plan for contingency funding at a confidence level that satisfies their risk tolerance. 